University of Louisville

ThinkIR: The University of Louisville's Institutional Repository

Electronic Theses and Dissertations

$12-2018$

\title{
The history and signification of the Navicella Mosaic at St. Peter's Basilica, Rome.
}

Eston Dillon Adams

University of Louisville

Follow this and additional works at: https://ir.library.louisville.edu/etd

Part of the Ancient, Medieval, Renaissance and Baroque Art and Architecture Commons

\section{Recommended Citation}

Adams, Eston Dillon, "The history and signification of the Navicella Mosaic at St. Peter's Basilica, Rome." (2018). Electronic Theses and Dissertations. Paper 3072.

https://doi.org/10.18297/etd/3072

This Doctoral Dissertation is brought to you for free and open access by ThinkIR: The University of Louisville's Institutional Repository. It has been accepted for inclusion in Electronic Theses and Dissertations by an authorized administrator of ThinkIR: The University of Louisville's Institutional Repository. This title appears here courtesy of the author, who has retained all other copyrights. For more information, please contact thinkir@louisville.edu. 
THE HISTORY AND SIGNIFICATION OF THE NAVICELLA MOSAIC AT SAINT PETER'S BASILICA, ROME

\author{
By \\ Eston Dillon Adams \\ B.A., University of Louisville, 2002 and 2006 \\ M.A., University of Louisville, 2011

\begin{abstract}
A Dissertation
Submitted to the Faculty of the

College of Arts and Sciences of the University of Louisville

in Partial Fulfillment of the Requirements

for the Degree of
\end{abstract} \\ Doctor of Philosophy \\ in Art History \\ Department of Fine Arts \\ University of Louisville \\ Louisville, Kentucky
}

December 2018 
Copyright 2018 by Eston Dillon Adams

All rights reserved 

THE HISTORY AND SIGNIFICATION OF THE NAVICELLA MOSAIC AT SAINT PETER'S BASILICA, ROME

By

Eston Dillon Adams

B.A., University of Louisville, 2002 and 2006

M.A., University of Louisville, 2011

A Dissertation Approved on

3 December 2018

by the following Dissertation Committee:

Dr. Christopher Fulton

Dr. Blake Beattie

Dr. Thomas Maloney

Dr. William Levin 


\section{DEDICATION}

This dissertation is dedicated to Jennifer A. Reeves, our children,

Tyler, Idalee, and Winston,

my parents James and Betsy Adams,

and my sister

Samantha Brooke Adams

with love. 


\section{ACKNOWLEDGMENTS}

I thank my advisor and dissertation director Dr. Chris Fulton for his expert guidance during my progress through the Art History $\mathrm{PhD}$ program, and for his gift of positively unwavering support. I also thank the other three outstanding members of my dissertation committee: Dr. Blake Beattie for putting me to the test, Dr. Thomas Maloney for boosting my confidence, and Dr. Bill Levin for the numerous ways he helped me to improve this work. It was an honor and pleasure to be under their tutelage. 


\title{
ABSTRACT \\ THE HISTORY AND SIGNIFICATION OF THE NAVICELLA MOSAIC AT SAINT PETER"S BASILICA ROME
}

\author{
Eston Dillon Adams
}

December 3, 2018

The Navicella mosaic is most famously an artwork created by Giotto di Bondone. Evidence for the appearance and dating of this giant mural is discussed in this dissertation with the conclusion that it was made in 1298 and its composition is best recorded in a Parri Spinelli drawing preserved in the Musée Condé in Chantilly, France. It was admired by untold numbers of worshipers who visited the grand Constantinian basilica of Old St. Peter's in the Vatican in Rome. The Navicella was located on the façade of Santa Maria in the Towers, an important chapel as well as the gatehouse affording entrance into the beauteous atrium of the church. Beginning in the sixteenth century and continuing into the seventeenth century Constantine's building was gradually demolished and replaced by New St. Peter's basilica, but this was not the end for Giotto's masterpiece. A copy of the mosaic can be seen today in the narthex above the central entrance into the church, comparable to its original location.

Just as Giotto's Navicella was reconstructed for the new basilica, it is argued here that Giotto's mosaic was the replacement for a mosaic mural that had existed on the gatehouse probably since the middle to late fifth century and that was eventually destroyed in 1167. That the subject matter of this ancient mosaic was, like Giotto's 
Navicella, a scene of St. Peter being raised up from the Sea of Galilee by the hand of Jesus Christ is accepted to be a strong likelihood.

Although Old St. Peter's basilica is no more, its atrium was the last feature to be demolished, continuing to exist into the early-seventeenth century, and the subject of detailed architectural surveys and visual documentation. This evidence for reconstructing the old atrium, and the late-sixteenth-century copies of the Navicella, is considered together with the inscription beneath the mosaic, exegetical material on Matthew 14:2236 (the verses which describe the event depicted in the Navicella), and writings on the symbolism of the mosaic's iconography in order to discuss the signification of the mural for worshiper's at Old St. Peter's during the late Renaissance. 


\section{TABLE OF CONTENTS}

PAGE

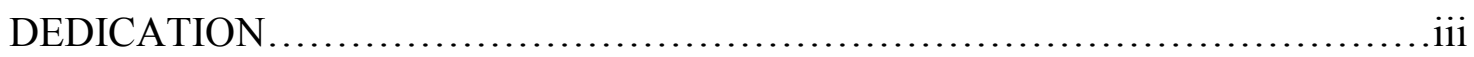

ACKNOWLEDGEMENTS .....................................................

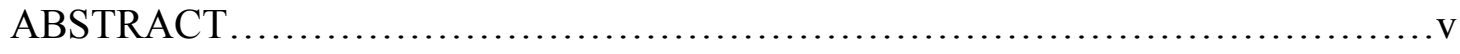

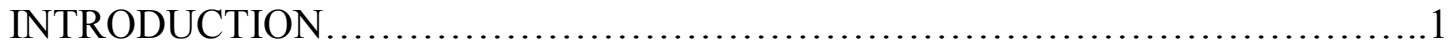

CHAPTER I The Navicella in the Forecourt of Old St. Peter's.......................5

CHAPTER II On the Appearance of Giotto's Navicella...............................23

CHAPTER III On the Date of Giotto's Navicella ...................................38

CHAPTER IV Towards the History of Giotto's Navicella ..............................57

CHAPTER V The Signification of the Navicella mosaic in the Late Renaissance Atrium

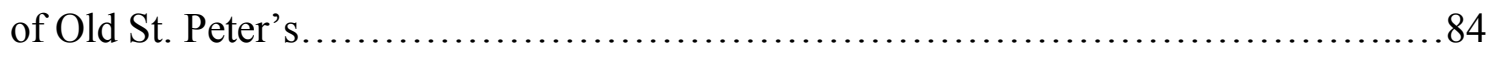

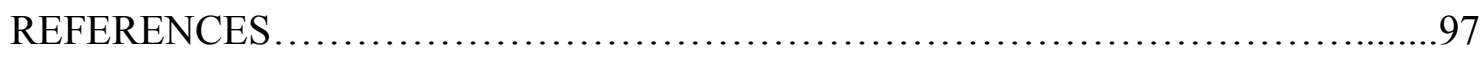

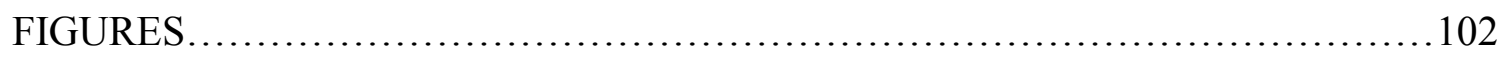

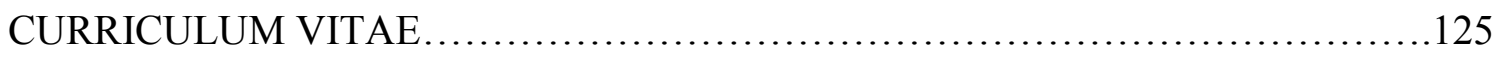




\section{LIST OF FIGURES}

$\begin{array}{lll}\text { FIGURE PAGE } & \text { PAR }\end{array}$

1. Giovanni Battista Falda, Reconstruction of Old St. Peter's atrium..............101

2. St. Peter rescued from the Sea of Galilee, Dura Europos..................... 102

3. View of Atrium of Old St. Peter's, Appartamento of Pope Julius III.............103

4. Nicolas Beatrizet, Copy of the Navicella (reversed)...........................104

5. Parri Spinelli, Copy of the Navicella, Metropolitan Museum....................104

6. Parri Spinelli, Adaptation of the Navicella, Cleveland Museum.................105

7. Parri Spinelli, Miraculous Draft of Fishes, Musèe Bonnat.....................106

8. Parri Spinelli, Copy of the Navicella, Musèe Condè............................107

9. Detail of Figure 8 under UV lamp (courtesy of Mme. Nicole Garnier).......... 108

10. Giorgio Vasari, autograph notes..................................... 108

11. Parri Spinelli, sketch for Sala di Balia fresco (verso of Figure 6)...............109

12. Spinello Aretino, Naval Battle, Sala di Balia in Siena......................... 109

13. Deodato Orlandi, Adaptation of the Navicella, San Piero a Grado in Pisa.......110

14. Adaptation of Navicella, Saint-Pierre-la-Jeune in Strasbourg..................111

15. Deodato Orlandi, Constanine, Pope Sylvester, and icon of Ss. Peter and Paul.112

16. Giacomo Grimaldi, Copy of fresco from atrium of Old St. Peter's.............113

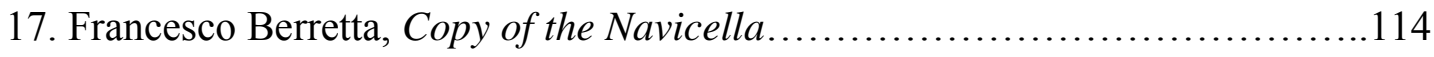

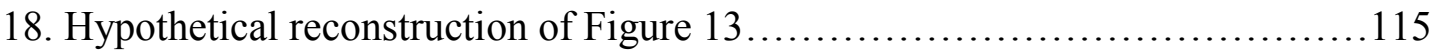

19. Andrea di Bonaiuto, Adaptation of the Navicella,S. Maria Novella in Florence116 


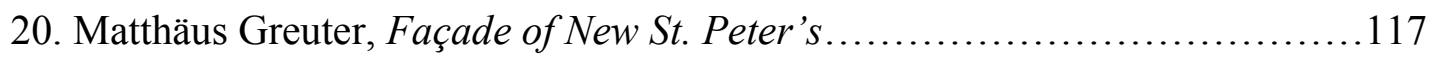

21. Nicoló Alunno, Adaptation of the Navicella, S. Maria in Campis in Foligno...118

22. Natale Bonifacio, Plan of Old St. Peter's (after design by Tiberio Alfarano)...118

23. Filippo Bonanni, copy of Medal of Pope Paul V ............................ 119

24. Orazio Manenti, The Navicella, Narthex of New St. Peter's in the Vatican......120

25. Giacomo Grimaldi, View of atrium of Old St. Peter's........................121

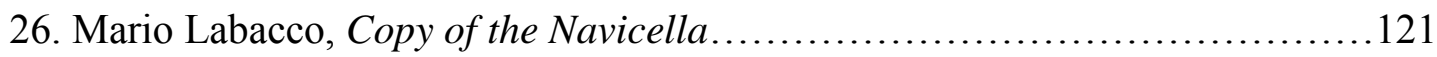

27. Bust of Angel from decorative frame of the Navicella, Vatican Grottoes........122

28. Bust of Angel from decorative frame of Navicella, Boville Ernica.............122

29. Circle of Pietro Cavallini, Traditio Legis from Apse of San Giorgio in Velabro123 


\section{INTRODUCTION}

The evidence, analysis, and conclusions contained in this dissertation will be of especial interest to those who study the history of St. Peter's basilica, to those who study the art of Giotto, and more generally, to those who study Christian art in its historical, architectural, and liturgical context. The Navicella is a supreme example of how Christian art cannot be fully understood apart from these factors. Even if each worshiper had a unique experience, the experience of every worshiper who entered Old St. Peter's forecourt and turned around to see the Navicella was influenced by the history, architecture, and liturgical use of the site. This dissertation aims towards bringing these factors into the clearest possible light.

The challenge to be met in this dissertation is to present the strongest evidence upon which to base an analysis of the signification of the Navicella mosaic in the late Renaissance atrium of Old St. Peter's in Rome. This is an artwork in an architectural context that were both completely destroyed four centuries ago, but fortunately, the Navicella has long been a frequently imitated artwork and the atrium of Old St. Peter's in Rome is a site which has long been the subject of scholarly inquiry. The types of primary data which are utilized as evidence for this reconstruction include inscriptions, numismatics, paintings, drawings, prints, sculptures, and written records, legal notices, descriptions, historical accounts and archeological reports. The puzzle of the Navicella's history formed by this diverse evidence is pieced together with deductive reasoning. 
Viewing the Navicella as but one ornament (though an outstanding one) amongst the conglomeration of ornaments featured in the forecourt of Old St. Peter's is key to understanding its signification because the mosaic's architectural context, and the historical import of its architectural context was calculated to produce an effect on the worshipers. It indicated to them that they had passed the threshold into sacred space, and their prayers within this space were most efficacious for salvation and remission from sin. It did so through the image, its inscription, the surroundings, the history and traditions at the site and those of the papacy itself. The term signification is employed here to circumscribe both the interpretation of the mosaic and the anticipated action it signaled to the worshipers through these factors.

The first chapter of the dissertation considers the evidence for a mosaic which existed in the same location later occupied by the Navicella and the possibility of whether or not this earlier mosaic was of the same subject as the later one. A mid-fifth century origin of this mosaic is posited based primarily upon close analysis of the textual evidence. It is shown to be most likely that this mosaic was a Navicella scene, but the evidence is not entirely conclusive. These findings regarding the early mosaic's date and appearance have important ramifications for the analysis of the signification of the Navicella.

Chapter two introduces the controversies surrounding Giotto's Navicella. These are the scholarly arguments concerning the uncertain appearance, date, and interpretation of Giotto's mosaic. The attempt to resolve these controversies begins with establishing the appearance of Giotto's Navicella through the analysis of its potential copies and other related artworks inspired by Giotto's composition. The possible candidates for the most 
faithful copy of Giotto's mosaic are narrowed down to two, an early-fifteenth-century drawing by Parri Spinelli and a mid-sixteenth-century etching by Nicholas Beatrizet on the basis of their respective inscriptions.

Determining the date of Cardinal Jacopo Stefaneschi's commission to Giotto is the object of chapter three. This is a controversy which bears greatly upon the signification of the Navicella, because many scholars have closely linked the year of the commission to the mosaic's interpretation. A firm resolution is reached primarily through the sifting of textual evidence that the traditional dating of the commission to the year 1298 must be maintained. It is further discussed why this removes the delimiting factor of specific historical cirumstances from the signification of the mosaic.

Having presented the argument for the date of the commission, to resolve the conficting evidence of the Parri Spinelli drawing and the Nicholas Beatrizet etching is the object of chapter four. A reconciliation of the evidence is attempted by discussing two occasions when the Navicella's composition might have changed at a particular time associated with recorded damage and repairs to the mosaic that are reflected in the many artworks based upon the mosaic and their dates. Yet having reached the determination that the mosaic in the late Renaissance atrium of Old St. Peter's was not entirely Giotto's creation or Cardinal Stefaneschi's commission, but was referred to as such, only typifies the deliberate, meaningful, and overriding tendency at St. Peter's basilica to maintain continuity with the past.

The final chapter of the dissertation focuses upon the signification of the Navicella mosaic. This builds upon the evidence for the history of the mosaic in the atrium of Old St. Peter's since probably the fifth century. Owing much to the 
documentary work and historical research completed by Tiberio Alfarano and Giacomo Grimaldi, who were eye-witnesses to the Navicella's setting in the old forecourt before its demolition, there is plenty of evidence upon which to base a reconstruction of the image and its surroundings as it was in the second-half of the sixteenth-century. Based upon the facts of its history, late Renaissance appearance, and architectural context, the signification of the Navicella mosaic is found to be three-fold. It was a narrative image illustrating a biblical scene. It was a symbolic image visualizing the mystical understanding of the scene. And it was an iconic image, an object of prayer with a connection to God. 


\section{CHAPTER I}

\section{THE NAVICELLA MOSAIC IN THE FORECOURT OF OLD ST. PETER'S}

The main concern of this dissertation is the mosaic mural today known as the Navicella (Figure 1). ${ }^{1}$ From the Latin "navicula," this Italian term is a diminutive form of "nave," the Italian word for boat, and its full meaning could best be translated into English with a phrase like "precious, little vessel". Navicella is a centuries-old designation for the mosaic, retained in English, French, and German scholarship on the subject, that might give an onlooker pause because the scene is foremost a depiction of St. Peter raised up from the Sea of Galilee by the hand of Jesus Christ, while the other apostles are afloat in their little vessel in the background witnessing and responding to the main action.

The first explanation that would probably occur to a viewer for the seemingly misplaced emphasis of the name Navicella is that the small sailboat with the apostles aboard is the central element of the entire composition, with Jesus Christ and St. Peter shown aside at the right edge. While the vessel's centrality does provide a satisfactory basis for the name Navicella, it does not explain why that little boat is such a focal point of a giant mural in the forecourt of the Vatican basilica dedicated to St. Peter, the first

\footnotetext{
${ }^{1}$ This engraving was made by Giovanni Battisti Falda circa 1673: that is, about 63 years after the mosaic was removed from its original place in the forecourt of Old St. Peter's during the process of the basilica's demolition. Although a reconstruction, the image gives an impression of the Navicella in its architectural context. No comparable view of the Navicella in situ made by an eye-witness is extant. Regarding its impressive scale, the mosaic's dimensions were approximately 57 feet wide and 39 feet high, including its decorative frame.
} 
Vicar of Christ. The truth is that the vessel is symbolic of the Church, and its striking centrality within the image is but one means by which its allegorical import is visualized. Moreover, due to its presence within the forecourt of Old St. Peter's basilica, this symbol of the Church is so pregnant with meaning that it resists delimitation.

The word Church in its Christian dogmatic sense denotes the congregation of the faithful, rather than the more commonplace understanding of the church as a building in which the faithful gather for worship. The Church does have a physical component comprised by the living worshipers themselves (the Church Militant: those enduring trials), and it has a spiritual component as well because the Church also embraces all those who have died in Christ (the Church Penitent: those in Purgatory, and the Church Triumphant: those in Heaven). In particular, St. Peter is part of the Church-a very special part. Secundum Mattheum 16, 18: "Et ego dico tibi quia tu es Petrus et super hanc petram aedificabo ecclesiam meam." (And I [Christ] say to you that you are Peter and upon this rock I will build my church). ${ }^{2}$

At St. Peter's basilica in Rome - the church built atop the Prince of Apostles' purported relics - this verse allows for a multiplicity of meanings. Christ calls Simon bar-Jonah (whom he designates Peter in the above verse) a rock. At St. Peter's basilica, in accordance with Christ's foretelling, the church is built upon this rock. Again referring to the above verse, Christ announces that He Himself would build His church upon St. Peter. 1 Corinthians 12: 27 (NRSV) states: "Now you [the faithful] are the body of Christ and individually members of it." The Church, constituting Christ's body, did build the Vatican basilica (the church) upon St. Peter. St. Peter's basilica itself is thus Christ's

\footnotetext{
${ }^{2}$ This verse is presented here according to the Vulgate Latin because that is how it is inscribed in a broad gilt frieze around the drum of the dome in New St. Peter's. The specific wording of the verse in Latin also bears upon the signification of the Navicella.
} 
prophecy fulfilled. We have a church built by Christ (by the body of the faithful) on the rock (St. Peter).

To this should be added that Christ calls the Church to be built on the rock "My Church." This possessive evokes another important shade of meaning in the interpretation of Matthew 16:18. The sacred duty of the Roman pontiff, the pope (successor of St. Peter), is to preserve immaculate the teachings of Christ handed down to St. Peter, and to shun all corrupt doctrine by combating heresy, guaranteeing that the Church built upon St. Peter is Christ's. The threat of heresy, and more broadly temptation and sin, is likewise invoked in the equation of a boat with the Church.

Indeed, the history of symbolizing the Church as a boat sailing on dangerous waters can be traced as far back as the first-century epistles of St. Paul. In 1 Timothy 1: 19 (NRSV), St. Paul warns: "By rejecting conscience, certain persons have suffered shipwreck in the faith." Then, in the late second or early third-century, Tertullian wrote explicitly: "Caeterum navicula illa figuram Ecclesia praeferebat, quod in mari, id est saeculo, fluctibus, id est persecutionibus et tentationibus." (And so the Navicella as the figure of the church was preferred, in the sea, it is the age, upon the waves, it is persecution and temptation.) $)^{3}$ The very early origin of this symbol is closely paralleled by the very early appearance of images of the Navicella as a narrative subject. In the mid-third-century domus ecclesia (house church) at Dura Europos, such a fragmentary fresco is preserved in the baptistery (Figure 2).

This brings us to the discussion of when the Navicella mosaic first became an ornament of Old St. Peter's. The key example of Navicella scholarship to be

\footnotetext{
${ }^{3}$ Tertullian, De Baptismo: Adversus Quintilliam, in Jacques-Paul Migne ed., Patrilogia Cursus Completus, vol. 1 (Parisiis: Excudebat Migne, 1844), 1214.
} 
discussed in this chapter of the dissertation is the study of Wilhelm Paeseler. His work, Giottos Navicella und ihr spätantikes Vorbild, was published twice in 1941-once as an article in Romischen Jahrbuch für Kunstgeschichte vol. 5, and again as a monograph special issue of that same publication - and what makes his study so exceptional and important to this dissertation are his argument and evidence for the existence of a mosaic in the forecourt of Old St. Peter's that preceded and provided a "Vorbild" (model) for the famous Navicella mosaic by Giotto. Paeseler's study is also exceptional because the Navicella scholarship that followed its publication has acknowledged his work bibliographically, utilizing and building upon his textual sources and pictorial evidence, but has not commented much upon either the validity or the ramifications of his primary conclusion that Giotto's mosaic replaced another Navicella. However, his argument must be duly considered in any discussion of the history and signification of the Navicella mosaic in the forecourt of St. Peter's basilica.

In Paeseler's introduction he asserts that a mosaic representing St. Peter rescued from the Sea of Galilee covered the western façade of the gatehouse on the east end of the forecourt of St. Peter's since the late fourth century (not long after the date of the construction of the Constantinian basilica itself in 333-366). ${ }^{4}$ This prominent locationdirectly above the primary ingress and egress of the basilica's forecourt — was indisputably the confirmed place of the Navicella at a later date. ${ }^{5}$

\footnotetext{
${ }^{4}$ Wilhelm Paeseler, Giottos Navicella und ihr spätantikes Vorbild (Wien: Verlag Anton Schroll \& Co., 1941), 51. For the dating see: Richard Krautheimer, Corpus basilicarum Christianarum Romae, vol. 5 , (Città del Vaticano: Pontificio Istituto di Archeologia Cristiana, 1980) 172.

${ }^{5}$ The first mention of gates at the entrance of the atrium of Old St. Peter's is from an epistle of St. Paulinus of Nola, written in 396, describing a funerary banquet taking place therein. Jacques-Paul Migne, ed. Patrologia Cursus Completus, vol. 61 (Paris: J.P. Migne, 1861), 213: “in amplissimam gloriosi Petri basilicam per illam venerabilem regiam cerula eminus fronte ridentem, ut tota et intra basilicam, et pro januis atrii, et pro gradibus campi spatia coaretentur."
} 
Paeseler argues for this late-antique dating of the Navicella from a philological and epigraphic examination of the distich, or tetrastich, once inscribed below the mural. From his analysis of the inscription Paeseler concludes that its language indicates a chronological provenance well before the date upon which the writing was first recorded in or before $1347 .^{6}$ In drawing this conclusion he followed Phillipus de Wynghe, a sixteenth-century author who also recorded the inscription and asserted that the wording was Lombardic. ${ }^{7}$ De Wynghe suggested that, because the verses were beneath an image which he understood to be Giotto's creation "ab hinc [1]300", an earlier image of the same subject ("ante illam alia illeic fuisse") must have been replaced by Giotto's tableau but the same ancient inscription had been repeated. ${ }^{8}$

Discovering a strong verbal parallel to an inscription created for the tomb of Pope Damasus (366-384), Paeseler reckoned this to have been the period during which the mosaic and its accompanying inscription originated. ${ }^{9}$ Paeseler further connects the mosaic's origin with Pope Damasus's construction of a baptistery at St. Peter's, drawing the consequent conclusion that the mosaic symbolically refers to baptism. There is logic behind this train of thought because the moment depicted in the image is St. Peter's emergence from the water, following his immersion in it. But such an interpretation of

\footnotetext{
${ }^{6}$ See Giovanni Battisti de Rossi, Inscriptiones Christianae urbis Romae, vol. 2, part 1 (Romae: Ex Officina Libraria Pontificia, 1888), 316. De Rossi gives this terminus ante quem for the Sylloge Nicolai Laurentii, which provides the earliest record of the mosaic's inscription.

${ }^{7}$ The Lombards did not enter Italy until the late sixth century. The chronological implication of de Wyghe's statement is ambiguous.

${ }^{8}$ De Rossi, Inscriptiones Christianae urbis Romae, vol. 2, part 1, 323. De Rossi himself supports van Wynghe's assertion of an antique origin for the Navicella inscription and cites an example of another epigraph in the forecourt of St. Peter's basilica with a seventh-century origin that had been destroyed and then reproduced in the fourteenth century. De Rossi also cites Angelo Mai, Scriptorum veterum nova collectio (Romae: Typis Vaticanis, 1831), vol. 5, 105. Mai assigns a date prior to the $11^{\text {th }}$ century for the Navicella inscription.

${ }^{9}$ Paeseler, "Giottos Navicella", 159. The very similarly worded beginning of Pope Damasus's Latin inscription reads: "Qui gradiens pelagi fluctus compressit amaros." De Rossi, Inscriptiones Christianae urbis Romae, vol. 2, part 1, 252.
} 
the image would be undercut by the verse of the Gospel according to John: "although it was not Jesus himself but his disciples who baptized."10

Additionally, the evidence strongly suggests that the mosaic was created no earlier than the papacy of St. Pope Leo I the Great (440-461). The ecclesiastical author Marco Attilio Serrano in his De Septem Urbis Ecclesiis-a guidebook to the most illustrious churches of Rome and their history, monuments, and relics published for the jubilee year of 1575 and dedicated to Pope Gregory XIII - claims that Pope Leo the Great made an image for the eastern wall of the atrium. ${ }^{11}$ He forms this conclusion based upon Leo the Great's Sermon 27 on the Nativity. The relevant passage from the sermon reads in translation: "Even some Christians think that they behave devoutly when, before arriving at the basilica of the blessed Apostle Peter (which has been dedicated to the one living and true God), they climb the steps which go up to the platform on the upper level, turn themselves around towards the rising sun, and bow down to honor its shining disk." 12

Serrano draws from this quotation that in order to counter this idolatrous behavior, Leo the Great had an image created in the direction toward which the worshipers prayed, so that rather than treating the sun as an object of devotion, they would be paying honor to Jesus Christ, the true Sun of justice. The place that Leo the

\footnotetext{
${ }^{10}$ John 4:2 (New Revised Standard Version). This verse weakens, but does not prohibit, an allegorical reference to the sacrament of baptism. As shall be shown later, there are certain iconographic elements of the image not to be understood as accurate in the historical sense of the Biblical account of the event depicted, but they are intended to accurately enhance and lead the viewer to understand the deep spiritual sense of the scene. For example, perhaps we could see the image as an allegorical reference to Jesus baptizing St. Peter with the Holy Spirit, pulling him out of his worldly mire and into an intimate, unique relationship with God.

${ }^{11}$ Marcus Attilii Serrani, De Septem urbis ecclesiis (Romae: Apud Haeredes Antonij Bladij Impressores Camerales, 1575), 16-18.

${ }^{12}$ The Fathers of the Church: A new translation, vol. 93, St. Leo the Great: Sermons, trans. Jane Patricia Freeland and Agnes Josephine Conway (Washington, D.C., The Catholic University of America Press: 1996), 113.
} 
Great describes in his sermon at which worshipers knelt to pray eastwards in front of the basilica, would most probably have to be facing the rear façade of the gatehouse, the later-recorded location of the Navicella. To Leo the Great's description of the location can be added these details: approaching from the east, preceding the forecourt of Old. St. Peter's there was a large open square that terminated in ascending steps on its western end. ${ }^{13}$ Those steps led up to the gatehouse, affording entrance to the basilica's forecourt, which Leo the Great refers to as the platform on the upper level, above the lower open square.

Serrano does not provide any evidence to corroborate his report that Leo the Great created a mosaic in this location - the pope only laments the idolatrous practice in his sermon but does not mention his remedying the problem with a Christian image- - but Leo the Great's sermon does furnish solid evidence that such a Christian image did not yet exist in that place when he composed his sermon. Otherwise he would not have condemned the worshipers' prayers as being directed towards the sun, but would have understood them to be venerating the image that they faced. This gives a terminus post quem for the image on the western façade of the gatehouse as December 25,451 , the date when Leo the Great delivered his sermon.

This conclusion contradicts Paeseler's claim that Leo the Great's sermon provides no "Termini" for the gatehouse mosaic. ${ }^{14}$ Paeseler reasons that Serrano misread the Latin text of Leo the Great's sermon and that the Christian's turning to pray towards the sun

\footnotetext{
${ }^{13}$ Krautheimer, Corpus basilicarum Christianarum Romae, vol. 5, 262. Owing to the construction of a large level platform on the side of the Vatican hill for the basilica and the forecourt, this flight of steps up from the square had been planned from the foundation of the basilica. The number of steps grew over the centuries of the basilica's existence from 20 in 1375 to 35 in the pontificate of Paul II (1464-1471) as the level of the open square preceding the forecourt was gradually lowered.

${ }^{14}$ Paeseler, Giottos Navicella und ihr spätantikes Vorbild, 160, n.424.
} 
took place immediately at the top of the stairs and before entering the atrium through the gatehouse. This point is crucial for Paeseler's theory that the gatehouse mosaic originated during the pontificate of Pope Damasus, prior to Leo the Great's pontificate. Leo the Great's description of the location where the Christians would turn to worship the sun reads in Serrano's quotation of the original Latin: "priusquam ad beati Petri apostoli basilicam, quae uni Deo vivo, et vero est dedicata, perveniant, superatis gradibus, quibus ad suggestum areae superioris ascenditur converso corpore ad nascente se solem conflectant.",15

This description of the place-before arriving at the basilica, having overcome the steps, the platform of the upper courtyard being ascended-does not negate the possibility that the praying towards the east took place before the atrium or inside the atrium. However, Paeseler's theory would require that the Christian worshipers of Leo the Great's time knelt and prayed towards the east just moments before entering the atrium where towards the east there stood a monumental mosaic whose inscription beckoned them to prayer. No, it is much more reasonable to suppose that there was no gatehouse mosaic in the atrium when Leo the Great inveighed against praying towards the rising sun at St. Peter's in 451.

Serrano's discussion of the evidence passed down through Leo the Great's sermon is employed in the context of a Counter-Reformation (post-Tridentine) defense of the legitimacy of Christian images. Prior to excerpting from Leo the Great's sermon, Serrano quotes St. Gregory Thaumaturgus (third century) stating that the forecourt of a church in general has been a place for catechumens and penitents. ${ }^{16}$ Serrano then gives

\footnotetext{
${ }^{15}$ Serrani, De Septem urbis ecclesiis, 17. An English translation of this passage is provided above.

${ }^{16}$ Serrani, De Septem urbis ecclesiis, 15-16.
} 
his own account of the tradition in the Vatican basilica's atrium of devoted men and women turning to the east to venerate "the image of Christ and the apostles tossed among the waves." ${ }^{17}$ While there is no specific mention of St. Peter, this is indubitably a reference to the Navicella mosaic existing in his own day. ${ }^{18}$ Perhaps a fresco from the appartamento of Pope Julius III (1550-1555) in the Vatican Papal Palace preserves a visual record of the practice of praying towards the Navicella mosaic noted by Serrano. ${ }^{19}$ (Figure 3) The gatehouse is pictured on the far right of the mural; just above center in the painting sits the forecourt's enormous bronze pinecone beneath its canopy. To the right of the sculpture, three figures are genuflecting with hands folded in prayer facing eastward, toward the Navicella.

Directly following his quotation from Leo the Great, Serrano compares the conversion of old Roman buildings (i.e. Pantheon, Baths of Diocletian) to Christian purposes and the conversion of pagan feast days to Christian ones (i.e. Juno and Augustus Caesar to the Virgin and St. Peter). He then continues:

ut honor, qui a stulta gentilitate soli huic, quem videmus, tribuebatur, sapienter vero iustitiae soli Christo Iesu per illius imaginem reddatur. At si quis diceret imaginem recentem esse, \& ob id aliquam mihi dubitationem afferent, respondeo me non de imagine solum, sed de consuetudine loqui. Quis autem prohibet alia ibi antea fuisse imaginem?

(that honor, here by the foolish people paid to the sun, which we see, it was bestowed, wisely to the true sun of justice, Christ Jesus, [the honor] through the image returned to Him. But if anyone might have said the image to be recent, and about it some to me will allege doubt, I respond not from the image alone, but

\footnotetext{
${ }^{17}$ Serrani, De Septem urbis ecclesiis, 15: "Christi imaginem \& apostolorum inter undas fluctuantium."

${ }^{18}$ Serrani, De Septem urbis ecclesiis, 16.

${ }^{19}$ Three kneeling figures are depicted in the middle-ground of the fresco with their faces directed towards the Navicella mosaic depicted slightly above and to the far right. These figures could be praying towards the mosaic or perhaps begging for alms. Whatever the case may actually be for the three figures in the fresco, there are enough contemporary written records that refer to the practice of kneeling in prayer in front of the Navicella to establish the historicity of the tradition, even if we do not have a definite contemporary visual record of the practice.
} 
speaking from the customs. Who then prohibits another image being there before? $)^{20}$

In the above excerpt Serrano supplies his third example of pagan tradition being supplanted by Christian tradition (the worship of the sun converting to the veneration of the true Sun of Justice, Jesus Christ, through his image). This excerpt also shows Serrano's reason for his belief that Leo the Great made the image on the east side of the atrium.

So, Serrano's initial remark about the image on the east side of the atrium describes the Navicella ("Christ's image and that of the apostles amongst the surging waves"). In his reference to Leo the Great's work he mentions only Jesus Christ in the image. However, the fact that he mentions only Jesus Christ in the image is evidently a rhetorical device, inserted into his discourse comparing pagan and Christian traditions: the pagan temple yielded to the Christian church, Juno yielded to the Virgin, Augustus yielded to St. Peter, and the sun yielded to Christ. Furthermore, because Serrano directly adds to his statement regarding Leo the Great's making of an image_- "but if anyone might have said the image to be recent, and about it some to me will allege doubt"logically he must be conflating the Navicella of his day with Leo the Great's image.

This conclusion follows because, first, Serrano in the immediate context of this quote is referring to Leo the Great's image — and in the present "recentem esse." Second, he must be referring as well to those who had said that the Navicella existing in his own day was recent (that is, in terms of the millennium-and-a-half history of Christianity), because it was widely known to have been Giotto's work. Finally, in order to argue

\footnotetext{
${ }^{20}$ Serrani, De Septem urbis ecclesiis, 18. Serrano's insinuation is poignant here, that the customs of the Church do not allow for innovation, and this treatment extends for him to the image of the Navicella, which he regards like a custom of the Church, not to be an innovation but a preserved tradition.
} 
against the recentness of the image in the atrium, one would have to assert that Giotto's image was not new: rather that Giotto's Navicella was Leo the Great's image remade. In confirmation of this view is Serrano's closing question: "Who then prohibits another image being there before?"

To be sure, the fact that there was no Christian image on the east side of the atrium when Leo the Great composed his sermon does not rule out Serrano's claim that later in his papacy he made such an image, but neither does it confirm it. Serrano seems to have concluded from Leo the Great's taking notice of the problematic practice of worshiping the sun and preaching against it, that he resolved the issue himself by commissioning an important image like that one Serrano knew in his own time to exist on the eastern enclosing wall of the forecourt. Not an illogical conclusion, nor entirely improbable, given the several above-mentioned sources that support an early, premedieval origin of the image's inscription, but for us Serrano's attribution of the gatehouse mosaic to Leo the Great must be considered to have been proffered ex silentio. More conjectural support for a Navicella mosaic having originated during a timeframe from 451-526 can be supplied by Richard Krautheimer's comprehensive study of the architectural history of St. Peter's, which draws upon epigraphic evidence and the Liber Ponitificalis for this period. In the time span beginning with the pontificate of Pope Leo the Great and ending with Pope John I (523-526), the popes oversaw greatly significant architectural and ornamental work in the atrium of St. Peter's. During the papacy of Leo the Great, the entire façade of the basilica was decorated with a mosaic mural representing the Adoration of the Lamb by the Twenty-Four Elders. During the papacy of Symmachus (498-514), the atrium was architecturally enclosed on all four 
sides (previously it seems to have been open to the north and south), and this squarenow for the first time referred to as quadriporticus due to its four connecting gableroofed colonnades - was decorated with marble and mosaics representing crosses, palm trees, and lambs. Facilities to provide for the poor and pilgrims were added, too. ${ }^{21}$

Taken together, this positive evidence for building and decorating activity accords well with the characterization of the forecourt of St. Peter's at least since the mid-fifth century as the paradiso. ${ }^{22}$ The term connotes succor for pilgrims and the poor, the release from worldly cares, and the beauty of the surroundings. The theme of Christian triumph and salvation created by adding the imagery of Christ's Passion and His Second Coming would be in harmony with the symbolism of the Navicella, referring to Christ's unfailing, continual support for His beleaguered Church. It will be argued below that there is a strong element of eschatological and salvific meaning to be derived from the mosaic as well, which again complements the atrium's common appellation: paradiso.

During the pontificate of Gregory IV (827-844) we have a sure reference to a mosaic on the atrium-facing side of the gatehouse and also a possible reference to the practice of praying before it:

Necnon et in fronte paradisi iamfate aecclesiae principali musibo cuncta quae a priscis temporibus in eodem pariete erant diruta, velocitate nimia pingere ac restaurare decrevit. Renovavit simul et porticum eiusdem ecclesiae quae super gradus eius esse perspicitur, per quos populous orationis voto indifferenter habet ascensum.

(And also in the front of the paradise of the aforesaid principal church a mosaic all of which from previous times on the same wall was destroyed, with great speed it was decided to paint and restore it. Renovated alike also was the portico

\footnotetext{
${ }^{21}$ Krautheimer, Corpus basilicarum Christianarum Romae, vol. 5, 173-4.

${ }^{22}$ De Rossi, Inscriptiones Chrstianae urbis Romae, vol. 1, 55. See also Krautheimer, Corpus basilicarum Christianarum Romae, vol. 5, 173.
} 
of the same church which is to be seen above the stair, for those people who, having ascended, customarily offer a prayer.) $)^{23}$

This gives us a terminus ante quem for the creation of the mosaic "in the front of the paradise" along with the information that this mosaic was being restored from former times. The association of this area of the atrium with the prayers of pilgrims supports the continuance of the practice observed by Leo the Great, but the quote does not specify that the prayers are directed towards the mosaic, just suggestively that the people, having ascended the steps, offer their prayers. Here we are given no information on the subject of the mosaic.

Beyond that derived from the erstwhile inscription, our other key piece of evidence for a pre-Giotto Navicella in the forecourt of Old St. Peter's comes from Otto Morena's history of the deeds of the German Emperor Frederick Barbarossa. Otto Morena and his son Acerbus (both authors of the history) were from Lodi and, viewing the emperor as the protector of their homeland, followed Frederick Barbarossa's actions with keen interest. Acerbus even accompanied the emperor on his Roman campaign, resulting in Acerbus's death from plague. ${ }^{24}$ The anonymous third continuator of the history is the author of this crucial Latin passage that states:

fuerat supra scalam sancti Petri ante atrium ipsius ecclesie sancti Petri, ignem supponentes, ipsam ecclesiam combussere [. . .] Tota iam dicta ecclesia sancte Marie penitus combusta atque dissipata, exarsa est quoque ac destructa quedam mirabilis imago, que fuerat facta in muro ipsius ecclesie versus ecclesiam sancti Petri supra atrium ipsius ecclesie sancti Petri ex auro purissimo atque splendidissimo decorata, cuius similis in Italia nunquam fuit amplius visa et que fuerat facta ad imaginem domini nostri Iesu Christi; ante quem item quedam alia

\footnotetext{
${ }^{23}$ Louis Duchesne, Le Liber pontificalis, vol. 2 (Paris: Éditions E. de Boccard, 1981), 80-81. See also 84 n. 14 for Duchesne's affirmation that the location of the mosaic described in the given passage is the same as that which would later be occupied by Giotto's Navicella.

${ }^{24}$ Franz-Josef Schmale, "Überlieferung und Text des 'Libellus' des Otto Morena und seiner Fortsetzer" in Deutsches Archiv für Erforschung des Mittelalters, vol. 41 (1985), 439-440.
} 
pulcerrima imago facta ad imaginem sancti Petri et ex eodem auro deaurata stabat, que similiter exarsa atque liquefacta ac penitus destructa est.

(It was above the stairs at St. Peter's before the atrium of the same church of St. Peter's, a fire was set, to burn that church [. . . ] all the already mentioned church of Holy Mary was burned and ruined inside, and the fire destroyed with it a marvelous image, that was made on the wall of the same church nearby the church of St. Peter upon the atrium of St. Peter's out of the purest gold and of the most splendid appearance, the likes of which in Italy no better was to be seen and which was made to be an image of our Lord Jesus Christ; before whom stood also another most beautiful image of St. Peter out of the same gold, that was also burned and liquefied and thoroughly destroyed.) $)^{25}$

This historical event is corroborated by a passage in the Liber Pontificalis as well, except that the Liber Pontificalis makes mention only of the damage caused by the fire to the gatehouse of the atrium without specific reference to any image thereon. ${ }^{26}$ But this does not explain why both Krautheimer and Sible de Blaauw in their comprehensive surveys of the basilica's history assert that the Navicella made by Giotto succeeded an image of Christ, omitting the image of St. Peter explicitly referred to in the passage as having been burned alike (similiter exarsa).

The relevant passage in Krautheimer's study reads: "against the west wall of the gatehouse facing the atrium; on this wall, indeed, existed a mosaic of the Saviour, later replaced by Giotto's Navicella." 27 The footnote attached to this statement even refers to Paeseler's study of the Navicella explicitly: "Paeseler [. . .] interprets the sources correctly in our opinion." This emphatic agreement with Paeseler's study seems to be extended only to his analysis of the architectural history of the gatehouse, but evidently not his thesis regarding the pre-Giotto Navicella, which Krautheimer all but contradicts

\footnotetext{
${ }^{25}$ Monumenta Germaniae historica, scriptores rerum Germanicarum, nova series vol. 7: Ottonis Morenae et continuatorum historia Frederici I (Berlin: Weidmannsche Buchhandlung, 1930) ed. Ferdinand Güterbock, 203-4:

${ }^{26}$ Duchesne, Le Liber pontificalis, vol. 2, 416

${ }^{27}$ Krautheimer, Corpus basilicarum Christianarum Romae, vol. 5, 269.
} 
and certainly does not support, by stating that the prior mosaic in question was of the Saviour in contrast to the later mosaic, of the Navicella with Christ, St. Peter, and the Apostles.

A very comparable statement regarding the interpretation of the evidence, yet more explicitly contradictory to Paeseler's thesis, is found in de Blaauw's analysis of the atrium.

La porta dell'atrio "cum eneis portis et vicinis porticalibus" fu gravemente danneggiata dall'irruzione delle truppe di Frederico Barbarossa nel 1167. Il mosaico di Cristo sulla facciata dell'edificio della porta prospiciente l'atrio, "cuius similis in Italia nunquam fuit amplius visa", andò allora pressoché perduto. [. . .] Nella prima metà del $14^{\circ}$ secolo, sulla facciata della porta prospiciente l'atrio, fu steso un mosaic con una nuova iconografia il quale succedeva al mosaico di Cristo menzionato nell'8 $8^{\circ}$ secolo e danneggiato nel 1167. La nuova composizione raffigurava la barca degli apostoli, con Pietro e Cristo che camminavano sull'acqua.

(The entrance of the atrium "with the bronze doors and nearby porticoes" was gravely damaged by the irruption of the troops of Frederick Barbarossa in 1167. The mosaic of Christ on the façade of the edifice of the entrance facing the atrium, "the likes of which in Italy no better was to be seen", was then almost lost. [...] In the first half of the fourteenth century, on the façade of the entrance facing the atrium, was placed a mosaic with a new iconography that succeeded the mosaic of Christ mentioned in the eighth century and damaged in 1167. The new composition represented the bark of the apostles, with Peter and Christ that walked on the water. $)^{28}$

In these statements there is no reference to the study by Paeseler (his work is not listed in de Blaauw's bibliography either), but Paeseler's source (Morena shown fully above) in support of the existence of an image with both St. Peter and Christ is partially quoted, yet that the destroyed image also depicted St. Peter is not mentioned.

De Blaauw, in support of his claim that a mosaic of Christ was replaced by the new subject matter of Giotto's Navicella, cites an unpublished document (Censuali) from

\footnotetext{
${ }^{28}$ Sible De Blaauw, Studi e Testi no. 356: Cultus et decor, vol. 2 (Città del Vaticano: Biblioteca Apostolica Vaticana, 1994), 640.
} 
the Archivio Capitolare di San Pietro from the year 1384 that attests to the tradition of selling holy memorabilia "under the image of the Savior at the foot of the stairs."."29 For the iconography of the gatehouse mosaic prior to Giotto's new work - that is, necessarily earlier than 1337: the year of Giotto's death—-this document furnishes no proof. What this document does reveal about Giotto's gatehouse mosaic will be discussed in a later chapter.

A close reading of the passage by Morena's continuator reveals that the mosaic on the eastern façade of the gatehouse surely depicted both Christ and St. Peter. According to the Latin passage, St. Peter was shown standing before (ante quem [. . . stabat) the figure of Christ and is made from the same gold (ex eodem auro). What remains in doubt is whether or not this image was a representation of Christ rescuing St. Peter.

In brief, from the analysis presented so far it can be stated that there is no evidence for a mosaic mural on the western façade of the east enclosing wall of the atrium of Old St. Peter's prior to December 25, 451, but by some date most likely quite prior to $827-844$ (the span of Gregory IV's pontificate) a mosaic had been put in said place that, in those times, was in need of restoration. Then a mosaic in that same location was burned in 1167 that depicted at least, and apparently primarily, St. Peter standing before Christ.

\footnotetext{
${ }^{29}$ De Blaauw, Cultus et decor, vol. 2, 640, n. 134: "subtus ymaginem Salvatoris in pede scalarum." The Censuali are chronological records for the purpose of tracking papal clients and various expenses. Beyond that original purpose, the Censuali contain a wealth of reliable, circumstantial information regarding these transactions. For an edited excerpt of Censuali spanning the years 1403-1409 see: Eugène Müntz and Arthur L. Frothingham, Il Tesoro della Basilica di S. Pietro in Vaticano (Roma: Società Romana di Storia Patria, 1883), 6-9, n.1.
} 
Prior to 1347 Nicolaus Laurentius recorded the inscription below Giotto's

Navicella. That the inscription could only have been created for a scene with the

Navicella's narrative subject is evident from the text itself:

QUEM LIQUIDOS PELAGI GRADIENTEM STERNERE FLUCTUS

IMPERITAS FIDUMQUE REGIS TREPIDUMQUE LABANTEM

ERIGIS ET CELEBREM REDDIS VIRTUTIBUS ALMUM

HOC IUBEAS ROGITANTE DEUS CONTINGERE PORTUM

For the one stepping upon the waters of the sea You calm the waves:

The trusting and the fearful You guide, the faltering You sustain:

And You celebrate him again for his virtues.

Grant, O God, what is sought - to reach the safe harbor!

The first line refers obliquely to St. Peter walking upon the water and the second person verbs imply Christ to be the actor. The final line, by laying such emphasis on the word "portum", suggests the ship with the apostles. Therefore, the inscription would only be logically fitting to inscribe beneath an image with the Navicella's subject matter.

There is a division of opinion among scholars regarding the crucial, but uncertain, date of this inscription's composition. While some argue its Latin style belongs to a far earlier time period than 1347 and it was re-inscribed below Giotto's Navicella, other scholars argue that the verses were composed by Giotto's patron for the Navicella mosaic: Cardinal Jacopo Gaetani Stefaneschi. ${ }^{30}$ Stefaneschi was a Latin poet and in the 1290s composed his Opus Metricum in Latin hexameter: the same poetic form as the inscription. ${ }^{31}$ This intractable conflict need not lead to an impasse in the analysis.

\footnotetext{
${ }^{30}$ This alternative position dates back at least to 1642 when Sebastiano Vannini declared: "dal medesimo cardinale [Jacopo Stefaneschi] composto sopra al Centesimo Giubileo, pubblicato da Bonifatio VIII, et alli quattro già con bellissime lettere, da alcuni chiamate ecclesiastiche, in marmo intagliati nel fregio delle porte, che erano sotto la detta Navicella, sicuramente fatti da lui." Christina de Benedictis, "'La Vita di Pietro Stefaneschi' di Sebstiano Vannini" in Annali della Scuola Normale Superiore di Pisa. Classe di Lettere e Filosofia, Serie III, vol. 6, no. 3 (1976): 966.

${ }^{31}$ To those scholars favoring the pre-Giotto composition of the inscription: the aforementioned Angelo Mai and G. B. de Rossi as well as the ancient Philippus de Winghe, can be added Hubert Jedin: in Paeseler,
} 
If the philologically ascertained early date of the inscription's composition cannot be used to prove the existence of a pre-Giotto Navicella definitively—which, if somehow proven, it would - then neither would proof of Stefaneschi's composition of the inscription for Giotto's mosaic rule out the existence of such a mosaic. In the absence of any argument or proof negating the possibility of a pre-Giotto Navicella in the forecourt, and given the tendency, commented upon above, for the major mosaics at Old St. Peter's to retain a basic continuity of subject matter with the preceding work when restored, there is a strong likelihood that Paeseler's "Vorbild" was an historical reality. Most importantly, whether the gatehouse mosaic prior to Giotto's commission was a Navicella scene or simply a more iconic mosaic featuring Christ and St. Peter, this mosaic was a major feature of the atrium, like Giotto's mosaic: a special object of admiration and devotion.

Giottos Navicella und ihr spätantikes Vorbild, 158, n.410. Jedin was certainly one of the pre-eminent church historians of the $20^{\text {th }}$ c., author of more than 662 titles and, for the $2^{\text {nd }}$ Vatican Council (1961-65), appointed by Pope John XXIII to the preparatory commission for studies and schools and also conciliar expert of the German episcopate: José Goñi, "Monseñor Hubert Jedin in memoriam", in Scripta Theologica, vol. 13, no. 1 (1981): 231-238.

The weight of this consensus of expert opinion should not be dismissed without hard evidence to the contrary, but the counter-argument that the patron Cardinal Stefaneschi, as an ambitious Latin poet with the golden opportunity to display his verse so permanently and prominently, could have chosen to compose his own inscription to accompany the image has not been directly refuted either. The criticism of the philological position that remains tacit in the following question is matched by the silence of the philological argument in the sources: "Qual cosa più ovvia e più logica che lo Stefaneschi, poeta, ordinando a Giotto il lavoro, abbia voluto esso stesso esporre in versi il concetto di quella grandiose scena musiva?" Giuseppe Cascioli, "La Navicella di Giotto a S. Pietro in Vaticano" in Bessarion 32 (1916): 126. 


\section{CHAPTER II}

\section{ON THE APPEARANCE OF GIOTTO'S NAVICELLA}

The three great controversies surrounding Giotto's Navicella mosaic concern fundamental categories of art-historical data that are the standard basis for an analysis of any artwork. There is disagreement among scholars about the appearance and content of the work, the date of the work, and the interpretation of the work. Of these three points of contention, the interpretation of the Navicella as it appeared in the sixteenth century is the one with which this dissertation is most concerned, but because such an interpretation must take into account the date and appearance of Giotto's work, all three questions must be dealt with.

"The mosaic of the 'Navicella' in the portico of S. Pietro was for centuries Giotto's most celebrated and most frequently quoted creation." 32 It might be a shock to learn that even the appearance of such a grand, famous mosaic by one of the most studied, influential artists of all time has not yet been definitely ascertained, and although there are scholars who would consider the issue of the appearance of Giotto's mosaic settled, it cannot be denied a priori that there is still room for doubt. The Navicella that Giotto created for Old St. Peter's no longer exists, and due to this lamentable loss that occurred no later than 1674, when Orazio Manenti began an entirely new

\footnotetext{
${ }^{32}$ Raimond van Marle, The Development of the Italian Schools of Painting, vol. 3 (The Hague: Martinus Nijhoff, 1924), 12.
} 
Navicella mosaic in the narthex of New St. Peter's basilica, who could claim absolute certainty about this mosaic's appearance as it was when first completed more than three centuries prior to that event?

On one hand, for those who claim such certainty, the overall appearance of Giotto's Navicella is thought to have been captured best in an etched copy made by Nicholas Beatrizet in 1559 (Figure 4), which features an inscription proclaiming itself to be a copy of Giotto's mosaic in the atrium of Old St. Peter's. ${ }^{33}$ The inscription also gives the date as 1335 for the making of the mosaic, only a year or two before Giotto's death. There has not been any scholarly acceptance of this dating and it is not supported by evidence elsewhere, but it should not be ruled out based solely upon these facts. The reasons for dismissing such a late date will be discussed below in the chapter on the dating of the mosaic.

On the other hand, from far closer to Giotto's lifetime, and thus chronologically closer to the creation of his Navicella, a drawing (circa 1407) survives in the collection of the Metropolitan Museum of Art in New York City attributed to Parri Spinelli (Figure 5), featuring an inscription on the hull of the boat which is somewhat difficult to read in its entirety, but that states emphatically "la nave di giotto [. . . ] santo pietro a roma di musaicho" (the boat of Giotto [. . .] St. Peter's in Rome of mosaic.) Lionello Venturi, in a much-debated reconstruction of the history of changes to which the composition of Giotto's Navicella was subjected, concluded that this drawing most accurately documented the appearance of Giotto's original work, and that later artworks based upon the gatehouse mosaic showed that Giotto's original composition in the atrium of Old St.

\footnotetext{
${ }^{33}$ The most recent scholarly works to argue this view are Helmtrud Köhren-Jansen, Giottos Navicella: Bildtradition, Deutung, Rezeptionsgeschichte (Worms am Rhein: Wernersche Verlagsgesellschaft, 1993), 247-248 and Michael Viktor Schwarz, Giottus Pictor, vol. 2 (Wien: B. hlau, 2008), 257-259.
} 
Peter's had been gradually altered by later mosaicists. ${ }^{34}$ The validity of Venturi's stylistic and art-historiographical analysis has been heavily criticized, while his conclusion regarding the authenticity of Parri's drawn copy of the mosaic continues to be upheld by some based upon the firm evidence of the inscription. ${ }^{35}$

Three other drawings have long been considered to have a close relationship to the Metropolitan Museum of Art drawing of the Navicella (Figures 6, 7, and 8). These are preserved respectively in the Cleveland Museum of Art in Cleveland, Ohio, the Musée Bonnat in Bayonne, France, and the Musée Condé in Chantilly, France. Mark Zucker made a very strong argument to demonstrate that the Metropolitan Museum drawing was but the first stage in Parri Spinelli's adaptation of the Navicella's composition for a scene of the Miraculous Draught of Fishes (John 21:1-14). ${ }^{36}$ It can be readily seen that the Cleveland Museum and Musée Bonnat drawings do exhibit the same style as the Metropolitan drawing and a sequential evolution can be followed through which the Navicella composition becomes a Miraculous Draught of Fishes while maintaining a very strong echo of its archetype.

\footnotetext{
${ }^{34}$ Lionello Venturi, "La 'Navicella' di Giotto," in L'Arte, 25 (1922): 50, 66-69.

${ }^{35}$ Most recently this argument has been maintained by Salvatore Sansone and Silvia Maddalo, "Ideologia e tradizione di un soggetto iconografico prima e oltre Giotto," in Frammenti di memoria: Giotto, Roma e Bonifacio VIII, eds. Maria Andaloro, Silvia Maddalo, and Massimo Miglio (Roma: Istituto Storico Italiano per il Medio Evo, 2009), 41, n.14. The footnote, taking issue with Zucker's analysis (discussed below) of the drawing's significance reads: "Lo studioso non dà il giusto peso alla didascalia che accompagna il disegno, nonostante la assegni, con esattezza, a una mano del XV secolo... Si è visto invece come essa sia di grande importanza all'interno della tradizione iconografica e utile per stabilire che il disegno di New York sia il più vicino all'originale giottesco." From the sentence given here in bold italics it seems evident that Sansone and Maddalo believe that the arguments heretofore produced against the veracity of Parri's Navicella copy do not outweigh the evidence of the inscription, and yet they do not believe that the inscription alone has proved the drawing's full faithfulness to its model; further confirming evidence is needed. Also Francesca Flores d'Arcais, Giotto, $2^{\text {nd }}$ ed. (New York and London: Abbeville Press Publishers, 2012), 244-47. In her analysis of Giotto's Navicella, d'Arcais illustrates exclusively the Metropolitan Museum drawing by Parri Spinelli as a copy of the mosaic, yet her text reveals that she believes the composition and iconography of Giotto's work to be closer to that of the Beatrizet copy, for which she provides no illustration. It is thus unclear where she stands on this controversy.

${ }^{36}$ Mark Zucker, "Parri Spinelli Drawings Reconsidered,” Master Drawings, vol. 19, no.4 (1981): 431-437.
} 
The Metropolitan drawing is the first stage, providing the basis for the next two stages. The Cleveland Museum drawing, departing from its model, removes the tower and fisherman at the left as serene elements incongruous with the theme of increased action and peril in the new scene. Also, Parri increases the number of wind personifications at the upper left, adds a water personification below them, and consequently increases the number of apostles struggling with the rigging of the mast, which is tilted at a more extreme angle from the vertical. The difficult battle with the sudden storm is emphasized over the more equally balanced mixture of psychological and physical reactions of the apostles in the Metropolitan drawing. Christ and St. Peter are turned aside from the viewer so that they face each other. All changes consistently make the composition into a more naturalistic narrative and less iconic image.

The Musée Bonnat drawing furthers the transformation of the subject into a Miraculous Draught of Fishes by showing three apostles hanging over the side of the boat, struggling near the shore with the unmanageable catch. The seemingly extrabiblical feature of the wind personification at the upper left in this drawing actually serves as a subtle exegesis of the biblical text of the miracle of the fishes insofar as it illustrates the necessity for divine aid to successfully net such a catch. The relevant passage of the Gospel account reads:

Jesus said to them, "Children, you have no fish, have you?" They answered him, "No." He said to them, "Cast the net to the right side of the boat, and you will find some." So they cast it, and now they were not able to haul it in because there were so many fish. That disciple whom Jesus loved said to Peter, "It is the Lord!" When Simon Peter heard that it was the Lord, he put on some clothes, for he was naked, and jumped into the sea. But the other disciples came in the boat, dragging the net full of fish, for they were not far from the land, only about a hundred yards off. ${ }^{37}$

\footnotetext{
${ }^{37}$ John 21:5-8 (NRSV).
} 
The addition of the wind personification serves to represent the miracle of another heavenly intervention, enabling the apostles, who at first were not able to draw in the net to reach the shore with it. The divine wind blows the boat towards the shore, which has been extended vertically and provided with foliage, while three disciples are able only to hang on to the huge haul with both arms. In contrast to the Metropolitan drawing where the wind personifications are distressing the apostles, the reconfiguring of the scene shows the wind personification blowing the disciples toward the safety of shore.

A comparison of the Cleveland and Bayonne adaptations of the Metropolitan drawing shows that, inspired by Giotto, Parri was thinking about how to enhance the spiritual content of his composition through naturalistic means. In the Cleveland Museum version, the abundant evil forces of nature fight violently with the apostles in an attempt to cause their vessel to wreck; in the Musée Bonnat version the divine wind brings the ship safely ashore to meet with Christ.

Briefly putting aside the issue of the Metropolitan drawing's inscription, it can actually be argued that all three drawings "quoted" (to borrow van Marle's apt phrase) from the Navicella's composition because the enlarged figures of Christ and St. Peter are depicted to the far right of the array of apostles aboard the boat contending with the elements, but that all three depart from the Gospel account in the same way is evident, too, because, by comparison with the shoreline in front of the angler on the left in the Metropolitan drawing, Christ appears to be standing on a sketchily rendered shoreline in each of the three compositions. Thus it can be argued that none of the drawings refer exactly, in a strictly literal sense, to the scene of Christ walking on the water and rescuing 
St. Peter from the Sea of Galilee, which is nonetheless the undisputed subject of the biblical narrative of the Navicella.

Now, returning to the issue of the Metropolitan drawing's inscription, the possibility has been considered that Giotto's Navicella did in fact depict Christ standing upon the shore as he rescued St. Peter. ${ }^{38}$ This iconographical detail alone, whether it is absent or present, shows how drastically a small change in appearance can alter the interpretation of the image. Suffice it to say that such an obvious divergence from the scriptural account would become a significant feature of any interpretation because it would be evidence that the image was intending to go beyond representing the facts of the biblical narrative and into the realm of the allegorical.

That the Navicella is an allegorical image is not to be disputed either, because whether it is upheld that Parri Spinelli's drawing or the Nicholas Beatrizet etching is the truer copy of Giotto's Navicella, the figure of St. Paul is included as the steersman of the sailboat with the apostles in both versions (he replaces Judas, who is excluded). Therefore if one were to argue that Christ standing on the shoreline would have been impossible for Giotto to include in his composition because it is a departure from the biblical narrative, it would prohibit the inclusion of St. Paul in the image for he was not even a disciple of Christ at the moment depicted, let alone an apostle. On the contrary, if Giotto included the figure of St. Paul in his composition with the intent to allegorize his image, then why could he not also have depicted Christ on the shoreline for the same reason?

\footnotetext{
${ }^{38}$ Sansone and Maddalo, "Ideologia e tradizione," in Frammenti di memoria, 48-51. Also Maria Grazia Ciardi Dupré dal Poggetto, Il Maestro del Codice di San Giorgio e il cardinale Jacopo Stefaneschi (Firenze: Editrice Edam, 1981), 80-81.
} 
A discussion of the third drawing closely associated with Parri's Metropolitan drawing has been withheld until this point because it exhibits many qualities that do set it apart from the other three, and yet it is undoubtedly related (Figure 8). The Musée Condé drawing must be considered either a copy or an archetype of the Metropolitan drawing because no drawing could so closely resemble another in its precise details without there being a direct relationship. ${ }^{39}$ As either copy or archetype for the Metropolitan drawing, the Musée Condé drawing is set apart from the Cleveland Museum and the Musée Bonnat drawings because it was not developed as an original composition; or, to phrase it differently, it either followed closely or was closely followed by the Metropolitan drawing.

Owing to the generous assistance and acumen of Nicole Garnier, Conservateur Général du Patrimoine chargée du Musée Condé, a UV light photograph (Figure 9) has revealed the full inscription on the Musée Condé drawing, which had only been published previously as "S. Pietro". ${ }^{40}$ Garnier's UV examination revealed the full inscription on the

\footnotetext{
${ }^{39}$ Paeseler humorously and authoritatively states the case: "Wenn irgendwo im Bereich der Handzeichnung der Begriff der Kopie einen Sinn hat, dann hier im Falle des Pembroke [Metropolitan] —und Chantilly [Musée Condé]_Blattes." Paeseler, "Giottos Navicella und ihr spätantikes Vorbild," 103.

${ }^{40}$ Mme. Garnier also cordially shared information pertaining to a curious fact about the condition of the Musée Condé drawing that has remained unaccounted for in the scholarship over the years. Many published reproductions of the Musée Condé drawing show the far left-hand side of the drawing missing, removing the angler and the fictive architecture from the composition-yet the end of the angler's cane still appeared on the left edge of the folio, showing that, after the drawing was completed, this missing portion had been cut away for some reason. The removal of the architecture and angler from the drawing must have occurred prior to 1879 when, as published in Charles Ephrussi and Gustave Dreyfus, Catalogue descriptif des dessins de maîtres anciens exposés à l'École des Beaux-Arts mai-juin 1879 (Paris: Typ. G. Chamerot, 1879), 1 , the dimensions of the drawing are given as $27 \mathrm{~cm} . \times 31.7 \mathrm{~cm}-$ missing the leftmost $8 \mathrm{~cm}$. However, as Mme. Garnier explained, the architecture and angler had to have been rejoined with the rest of the composition no later than 1897, the date of the death of the duc d'Aumale (who acquired the drawing in 1865), because, per Mme. Nicole Garnier, email message to author, February 28, 2018: "Les dessins du duc d'Aumale (légués en 1884 à l'Institut de France avec son château de Chantilly et toutes ses collections pour former le musée Condé) ont été encadrés à sa demande dans la seconde moitié $d u 19^{e}$ siècle dans des montages en carton bleu et or avec filet d'encre de Chine, à l'imitation des célèbres montages de Pierre-Jean Mariette au $18^{e}$ siècle. Donc, si le dessin est encadré dans ce type de montage, cela prouve qu'il avait déjà les mêmes dimensions à la fin du $19^{e}$ siècle, et qu'il n'a pas été augmenté ensuite." The decorative mounting made during the duc d'Aumale's lifetime specifically to display the
} 
Musée Condé drawing to read, "La Nave' di Giotto ghe [sic] è nel cortile Di S. Pietro. Di [Roma?] Di Mosaico" (the boat of Giotto that is in the courtyard of St. Peter's of Rome of mosaic). Comparing it to the Metropolitan drawing's inscription, "la nave di giotto [. . . ] santo pietro a roma di musaicho," there is a very close correspondence in the placement of the inscription on the upper part of the boat's hull, and also in the inscription's wording and syntax other than the more precise indication of the mosaic's location, in the cortile of St. Peter's in Rome, given in the inscription on the Musée Condé drawing. The inscription of the Metropolitan drawing is a small notation in three lines of Parri's hand and was made at the time of the drawing. The inscription of the Musée Condé drawing is not in Parri's hand, and therefore not contemporary with the drawing, displayed in a single line of bold, very neat, calligraphic lettering. Due to the parallel wording and placement of the two inscriptions it must be concluded that an owner of what was later to become the Musée Condé drawing transferred the inscription from the Metropolitan drawing and embellished it slightly.

The provenance of the Metropolitan and the Musée Condé drawings—as well as the drawings in Cleveland and Bayonne — can be traced back to none other than Giorgio Vasari, the famous biographer of artists and a dutiful collector of drawings. Besides preserving the drawings, he also worked some of them into his Lives of the Artists as frontispieces for biographies, and for these drawings he created decorative architectural frames. Traces of such framework can be seen on the outer side edges of the

Navicella drawing provides an opening for the viewing of the full dimensions of the folio $27 \mathrm{~cm} . \mathrm{x} 39.7 \mathrm{~cm}$. and proves that the portion which was cut away prior to the exposition of 1879 had been restored at the time of its fashioning. Yet, presumably the portion of the drawing with the angler and architecture must have entered the duc d'Aumale's collection along with the rest of the drawing in order for the two to have been framed together prior to his death. The issues of when and for what reason the angler and architecture were cut from the rest of the drawing remain unresolved and intriguing. 
Metropolitan and Cleveland sheets in the form of column bases and capitals. ${ }^{41}$

Additional substantiation of Vasari's ownership of these drawing comes from his biography of Parri Spinelli where he states: "E nel nostro libro sono alcune carte da lui [Parri] disegnate di penna molto bene." ${ }^{42}$ The possibility remains that Vasari himself was the collector, possessing both the Metropolitan and Musée Condé sheets, who added the bold, calligraphic inscription to the Musée Condé drawing. Figure 9 is a detail of an autograph page in Vasari's hand and there is a definite resemblance to the handwriting of the Musée Condé inscription. In particular, compare the upper case P's and D's, and upper and lower case G's from both sheets. ${ }^{43}$

Now, on the basis of their respective inscriptions, one of these two drawings cannot be exactly what it might be assumed to be. For each seems to assert by its inscription that the drawing is a copy of Giotto's Navicella mosaic, however only one could be truly derived directly from the mosaic; while the other would have to be a copy from a drawing of the mosaic. But which is the original drawing of the mosaic and which is the drawing that followed the original drawing of the mosaic?

The differences in the two drawings are foremost stylistic ones, with the Metropolitan drawing showing more evidence of Parri’s free, open, calligraphic styleespecially noticeable in the figures' hair and drapery and in the architecture on the left, while the Musée Condé drawing is far more precise. If the attribution of the Musée Condé drawing to Parri Spinelli is accurate, then clearly Parri suppressed his personal

\footnotetext{
${ }^{41}$ See Claus Virch, “A Page from Vasari's Book of Drawings," The Metropolitan Museum of Art Bulletin, New Series, vol. 19, no. 7 (Mar., 1961): 185-193.

${ }^{42}$ Giorgio Vasari, Le Vite de' più eccelenti pittori, scultori, e architettori, eds. Paola Della Pergola, Luigi Grassi e Giovanni Previtali (Novara: Istituta Geographico de Agostini, 1967), vol. 2, 220.

${ }^{43}$ Additional support for Vasari's authorship of the Musée Condé drawing's inscription can be derived from his life of Giotto. He describes the location of Giotto's Navicella as "nel cortile di San Pietro", using the exact same term for Old St. Peter's atrium as in the Musée Condé drawing's inscription. Vasari, Le Vite de' più eccelenti pittori, eds. Della Pergola et al., vol. 2, 122.
} 
style to give a faithful rendering of the mosaic, or his mature style had not yet developed when the drawing was made. Either alternative would be a point in favor of the precedence of the Musée Condé drawing.

A second major difference between the two drawings is that in the Metropolitan drawing Christ's head is turned slightly to his right, toward St. Peter, while in the Musée Condé drawing Christ's head is shown entirely frontally. In Parri's drawings in the Cleveland Museum and the Musée Bonnat, the body and head of Christ have been turned even more toward St. Peter. That repositioning of Christ's head is one bit of evidence that, starting with the Metropolitan drawing, Parri was adapting Giotto's composition for his own purposes. If the Musée Condé drawing did copy the Metropolitan drawing, then why does it not show Christ's head turned towards St. Peter, too, when in all but one other iconographic respects (discussed below) it is exactly the same? If, on the other hand, the Metropolitan drawing copied from the Musée Condé drawing, this change can be understood as a step in Parri's creative process.

A third difference to be found between the Metropolitan and Musée Condé drawings is perhaps the most telling. In the Metropolitan drawing, directly above the figure of St. Peter, Parri has depicted three openings in the boat's hull, which appear to be oar ports. This detail, not found in the Musée Condé sheet, occurs in the Cleveland drawing, where in fact Parri has depicted ten such oar ports (one for each apostle in the boat, with St. Paul at the rudder). It contributes significantly to the conclusion that the Metropolitan drawing was copied from the Musée Condé drawing.

Contrary to the idea that the Metropolitan drawing was fully intended to be a faithful reproduction of Giotto's Navicella mosaic, it is just not believable that Giotto's 
Navicella mosaic would feature a boat with only three oar ports in the front. Such openings are a realistic detail, but, to imitate an actual sailing vessel, they would have to line the entire side of the hull, not merely the bow. And the absence of the oar ports along the stern of the boat cannot be explained simply by the presence of the inscription in the middle because there is plenty of room to the left of the inscription for the series of oar ports to continue if the drawing truly were a faithful rendering of the boat in Giotto's mosaic.

In this detail, at least, it seems that the Metropolitan drawing departed from Giotto's tableau, where the boat probably lacked oar ports. The Cleveland drawing, in contrast, shows a more accurately realistic depiction of oar ports lining the hull of the boat from bow to stern. That Parri did not derive the oar ports from the Navicella mosaic or the Musée Condé drawing strongly suggests that in the Metropolitan drawing he was beginning the creative process of altering his model— the Musée Condé drawing derived from mosaic - toward the Cleveland adaptation of the Navicella by experimenting with the addition of oar ports. ${ }^{44}$

This evidence, along with the turned head of Christ and the stronger presence of Parri's personal style, point to the conclusion that Parri began to incorporate his own ideas into the Metropolitan adaptation of the Navicella, itself based upon the Musée Condé drawing. The latter's more precise Giottesque style, the fully frontal Christ and the complete absence of oar ports indicate that the Musée Condé drawing was a more faithful copy of Giotto's Navicella.

\footnotetext{
${ }^{44}$ That Parri likewise experimented with the appearance of the boat's stern in the Cleveland and Bayonne drawings supports that tinkering with the hull of the boat's features was on his mind from the beginning of his creative process.
} 
To help explain the motivation behind this series of drawings, one theory holds that the sheets were kept together by Parri as a ship-model drawing-book due to the coinciding dimensions of the sheets as well as the naval subject matter. ${ }^{45}$ All four drawings do share those qualities, but there are several reasons for considering the Musée Condé drawing the outlier of the group. As if at one time they had been kept one on top of the other, the Cleveland, Bonnat, and Metropolitan drawings all have the same damage to the upper right-hand corner of sheet, which the Musée Condé drawing lacks. ${ }^{46}$ The Cleveland and Metropolitan sheets bear traces of having once been creased down the middle, shown by the effacement of the ink. The Bonnat drawing has no such effacement because it is half the size of the Cleveland and Metropolitan drawings and so would not have been folded across the spine of the book. Most noteworthy, the Cleveland, Bonnat, and the Metropolitan sheets each have sketches of boats on the verso, differentiating all three from the Musée Condé drawing, which has no verso drawing. ${ }^{47}$ All this evidence buttresses the conclusion that the Musée Condé drawing was made to record the appearance of the Navicella mosaic, while the other three drawings were consecutive experimental compositions.

One of the sketches on the verso also yields a very specific clue as to the chronological and geographical origin of the drawing series. On the verso of the Cleveland drawing are sketches of several ships engaged in a naval battle (Figure 11). Parri and his father Spinello Aretino worked together in 1407 on a fresco cycle in Siena's

\footnotetext{
${ }^{45}$ Bernhard Degenhart and Annegrit Schmitt, Corpus der italienischen Zeichnungen: 1300-1450, vol. 1 (Berlin, Gebr. Mann Verlag: 1968), 277-280.

${ }^{46}$ Virch, “A Page from Vasari's Book of Drawings," 189-190. Virch, like Degenhart and Schmitt, proposes the existence of a sketchbook containing the Metropolitan, Cleveland, and Bonnat drawings, but he excludes the Musée Condé drawing from belonging to the book.

${ }^{47}$ Zucker, "Parri Spinelli Drawings Reconsidered," 437.
} 
Palazzo Pubblico in a room known as the Sala di Balia with decoration that celebrates the deeds of Pope Alexander III, a native of Siena. The subject of one large mural is a naval battle between the Venetian forces on the side of the papacy and those of the emperor Frederick Barbarossa (Figure 12). Apparent in the sketches on the verso of the Cleveland sheet, some ships were intended to be those of the emperor because the distinctive form of the imperial eagle is depicted on a flag flying atop a mast (top middle) and on a quarterdeck (far right). This implies that the sketches on the verso of the Cleveland sheet were made in preparation for the naval battle scene in the Sala di Balia, for there is no evidence that Parri, on another occasion, was inspired to create sketches representing a naval battle involving imperial forces.

Parri was about 20 years old when working in the Sala di Balia, so there is good reason to believe that his copy of the Navicella was in fact a youthful work, first because that drawing must have been made prior to the drawing it inspired on the recto of the Cleveland sheet, upon which verso appears the preparatory sketches for the naval battle fresco, and second because it would be natural for him in his training to copy and adapt the work of an established master-especially Giotto, by whose style Parri's father Spinello was so strongly influenced—as recommended by his contemporary Cennino Cennini in Chapter 27 of his Libro dell'Arte. ${ }^{48}$

Having presented the stylistic and physical evidence of the four drawings under consideration, the Musée Condé's copy of the Navicella is logically the first, made in or

\footnotetext{
${ }^{48}$ The famous passage: "Having practiced drawing a sufficient time on tablets as I have before directed, always take pains in drawing the best subjects which you can find, done by the hand of great masters. If you live in a place where there are many good masters, so much the better for you. But I counsel you always to choose the best and most famous; and by daily following him, it will be against nature if you do not come close to his manner and style." C. J. Herringham trans., The Book of Art of Cennino Cennini (London: G. Allen, 1899), 21-22.
} 
before 1407, when the work on the Sala di Balia commenced. If, as the inscription indicates, it was drawn from Giotto's Navicella in the cortile of Saint Peter's in Rome, then Parri must have been in Rome prior to his work in Siena. Parri was never documented as having worked in Rome, but the year 1400 was a jubilee year for the Church and, given the huge crowds of pilgrims that were reported to have visited Saint Peter's basilica to obtain remission from sin, it would have been a perfect time for Parri and his father to have visited the basilica as pilgrims and not as commissioned artists.

At this time Parri, the young artist in training, maybe upon his father's suggestion, could have studied and made a drawing after Giotto's Navicella. Years later, as a more mature artist, when he decided to adapt Giotto's composition for his own experimental series of drawings he used the Musée Condé drawing as the basis for the Metropolitan drawing, adding its inscription to document the artwork he knew to be his drawing's inspiration. In his first adaptation he copied the Musée Condé drawing almost line for line, introducing only subtle changes (his own line quality, the oar-ports and the slightly turned Christ, altering the composition very little). The Cleveland and Bonnat sheets, being too far removed from Giotto's composition, were not inscribed by Parri. In the sixteenth century Giorgio Vasari, having come into possession of all four drawings, recognized that the Metropolitan and Musée Condé drawings were almost identical. So, on the basis of the Metropolitan drawing's inscription, he added an inscription to the Musée Condé drawing with flourish.

Concerning an accurate reproduction of the original appearance of Giotto's Navicella, the possibilities are narrowed now to the two most reasonable candidates: the Musée Condé drawing and Nicholas Beatrizet's engraving. In order to ascertain which of 
these two more closely resembles Giotto's own original composition it is necessary to address the issue of the dating of Giotto's Navicella as well. 


\section{CHAPTER III}

\section{ON THE DATE OF GIOTTO’S NAVICELLA}

The evidence that Giotto's Navicella was created as a mosaic mural that was preceded by another mosaic mural in the same location is scant, but not purely conjectural: the earlier mosaic represented, at least, Christ with Saint Peter standing before him. But it is a matter of conjecture, drawn from the philological analysis of the mosaic's accompanying inscription, that this mosaic was a Navicella scene like Giotto's. These data raise two crucial questions. Why was it necessary for Giotto to create a replacement? What was the degree to which his work imitated its predecessor?

For the first question we return to the blaze set by the troops of Frederick Barbarossa, burning the gatehouse of St. Peter's and melting the glass tesserae from the mosaic on its façade in 1167. Paeseler believes the extent of the damage done to the mosaic by the arson was exaggerated by the pro-papal, anonymous, continuator of Otto Morena's history in order to cause the reader to view the emperor's actions more negatively due to his destruction of such a beautiful image. ${ }^{49}$ Ferdinand Güterbock, the editor of Otto Morena's history, also notes the shift in political standpoint of the continuator from pro-imperial to pro-papal. ${ }^{50}$

As mentioned in the first chapter, the account of the fire set by Frederick Barbarossa is corroborated by the Liber Pontificalis, which is, of course, also pro-papal.

\footnotetext{
${ }^{49}$ Paeseler, "Giotto's Navicella und ihr spatantike Vorbild," 162.

${ }^{50}$ Ottonis Morenae et continuatorum historia Frederici I, ed. Ferdinand Güterbock, XXVII.
} 
The author of the section of the book which deals with the events of 1167 was Cardinal Boson, Master of the Apostolic Chambers under Pope Alexander III, during whose papacy Barbarossa's siege took place. ${ }^{51}$ His description of the damage done by the profaning fire reads: "post combustam sancte Marie in Turri ecclesiam cum eneis portis et vicinis porticalibus" ${ }^{" 52}$ This wording states that the gatehouse (sancte Marie in Turri) and its bronze doors were consumed by fire, as were the nearby porticoes. The mention of the porticoes being burned as well is useful because it indicates that the fire had reached inside the atrium. ${ }^{53}$ This architectural space was lined on all four interior sides by porticoes, hence one of that space's common designations: the quadriporticus. ${ }^{54}$ Cardinal Boson's indication that the damage from the fire extended into the atrium lends support to the claim that the mosaic on the western façade of the gatehouse was burned, as reported in detail by the anonymous continuator of Otto Morena's history. It is also reasonable to assume that this fire was progressing towards the basilica proper because, as Cardinal Boson states in the same passage, the pope relinquished the basilica into imperial hands in order to prevent the entire church from being destroyed.

If we are to follow Paeseler's reasoning and subscribe to the notion that the predecessor of Giotto's Navicella mosaic was not as completely destroyed by Frederick Barabarossa's arson as the pro-papal historian would have us believe, then one must wonder what sort of mosaic remained and was it repaired prior to Giotto's work? If we

\footnotetext{
${ }^{51}$ Duchesne, Liber Pontificalis, vol. 2, 351.

52 Duchesne, Liber Pontificalis, vol. 2, 416. Duchesne also footnotes here that the bronze doors (eneis portis) that were burned by Barbarossa's troops were inscribed in silver letters that listed the cities donated to Pope Hadrian by Charlemagne. Due to the conflict between imperial and papal authorities raging in 1167 at St. Peter's, the destruction of this ancient reminder of the goodwill that existed between the anointed emperor and the pope would have resonated like the burning of an effigy.

${ }^{53}$ A view explicitly supported in Krautheimer, Corpus basilicarum Christianarum Romae, vol. 5, 270.

${ }^{54}$ The first instance of this appellation (quadriporticum) for the forecourt of St. Peter's is recorded in the history of the papacy of Pope Symmachus (498-514) in the context of this pope having enclosed (conpaginavit) the atrium: Duchesne, Liber Pontificalis, vol. 1, 262.
} 
are likewise to follow the conjecture that the inscription recorded below Giotto's mosaic was retained — proof that the preceding mosaic represented the same subject—how much of Giotto's iconography was new?

Yet one must conclude as well, if Morena's continuator was trying to mar the reputation of Frederick Barbarossa by characterizing his actions as atrocious, there is a kernel of truth to the story in that there existed a widely known and admired image on the gatehouse of St. Peter's, such that it would have been considered tragic and probably sacrilegious to destroy. If it were otherwise, the continuator could not have counted on his account to provoke any ire against the emperor. But by using this sacred, beautiful image as a touchstone for his reader, he could rest assured that his audience would consider Barbarossa's actions rash and impious.

On this basis it also stands to reason that the damage done to the gatehouse mosaic was evidently significant, otherwise the veracity of his whole account would be undermined. Given that both historical accounts of the fire testify that it was effective in securing the temporary victory of Frederick Barbarossa, the fire must have damaged the atrium and threatened the basilica. Therefore, it is safe to say that, whether the glass mosaic was melted entirely by the fire or not, it was left in deplorable enough condition to merit at least a restoration if not an entire rebuilding.

Now, if Giotto's work was the first replacement or restoration work done following the actions of Frederick Barbarossa, then more than a century passed between the two campaigns. Is it plausible that a partially burned remnant of reputably the oncemost-beautiful mosaic in Italy remained on the charred façade of the gatehouse of St. Peter's for that long? In favor of this possibility it can be imagined that just as pro-papal 
historians were interested in casting pro-imperialists as villains and vandals, so the visible remains of this attack on a sacred site would be strong reinforcement of that view for all the multitudes who visited the church. The evidence of the fire damage could even cast the lot of the pro-imperialists in with the invading Islamic armies of 846 , the only other instance when an army had the temerity to attack the Vatican basilica—an alignment that no professed Christian would desire. ${ }^{55}$

Such a stratagem could arouse some serious popular sympathy for the papacy as a beleaguered victim or a suffering confessor. Likewise, if the damaged mosaic remained until Giotto's time, that itself would constitute an obvious motivation for its restoration or replacement in light of the extinction of Barbarossa's Hohenstaufen dynasty in 1268; the goal would have been to remove the offensive sight and restore the atrium's former beauty. It is implausible to think that, after Barbarossa's time, later popes and the hierarchy of the church of St. Peter's would have left unrepaired such a displeasing sight as the burned façade of the gatehouse out of indifference or lack of means for its remedy.

A very important point in favor of the predecessor to Giotto's Navicella representing St. Peter saved from the Sea of Galilee by Christ is that maintaining continuity of subject matter in major mosaic murals is consistent with the history of the ornamentation of Old Saint Peter's. Both the restored apse mosaic of Pope Innocent III and the restored façade mosaic of Pope Gregory IX retained the basic subject matter of their predecessors. ${ }^{56}$ Note also that later, during the seventeenth century, the Navicella

\footnotetext{
${ }^{55}$ The Islamic incursion upon Old St. Peter's occurred during the pontificate of Pope Sergius II and is recorded in: Duchesne, Liber Pontificalis, vol. 2, 99-101.

${ }^{56}$ The apse mosaic's subject remained Christ flanked by Saints Peter and Paul above a register of lambs in procession, and the façade mosaic remained a representation of the Adoration of Christ at his Second Coming. Both of these twelfth century restorations also involved some pointed modifications of the mosaics' iconography, as would have, presumably, Giotto's work on the gatehouse mosaic.
} 
mosaic itself had to endure a great struggle to maintain continuity of architectural context and appearance during the construction and ornamentation of New St. Peter's. ${ }^{57}$

There is primary historical evidence for large-scale repairs to the gatehouse during Giotto's lifetime but prior to his having worked there. The first notice of repairs to the gatehouse following the fire of 1167 is in 1285 under Pope Honorius IV, recorded in an account book in the Vatican Archives. It was during this intervening period of 118 years that the restoration of the aforementioned apse and façade mosaics of Old St. Peter's was undertaken and recorded, while there is no such record for the mosaic on the atrium-side façade of the gatehouse, even though it may have needed the work much more than the other two. Yet combined with this lack of evidence for previous remediation, the apparent extent of the work undertaken in 1285, according to the record, makes it possible to associate some of it with such repairs as would have been necessitated by the fire of 1167. An English translation of the relevant entries follows:

This contains expenses for labor on the church of Blessed Peter, year 1285.

First, on an iron railing placed at the fountain of the Paradise.

Sunday 22, July: Five master masons stayed to labor and wall the façade of Santa Maria in the Towers [the gatehouse] for six days with twenty-two workers at a rate of three soldi for the work - totaling three libre and six soldi.

Nine manual laborers for the said days at the same work with forty-eight workers at a rate of two soldi and twenty denarii for the work - totaling four libre, five soldi and eight denarii.

Three other manual laborers for the said days with fifteen workers at a rate of fifteen denarii for the work - totaling eighteen soldi and nine denarii.

The same days nine master carpenters to carve panels and to make temporary molds (mutellos positos) on the same façade for the said days with forty-five

\footnotetext{
${ }^{57}$ This history is well-rehearsed and documented in G. Cascioli, "La Navicella di Giotto" in Bessarion 32 (1916): 132-138.
} 
workers at a rate of forty denariis and three soldi for the work - totaling seven libre, four soldi and eight denarii.

Sunday 5 August: Five master masons adjoined to work on Santa Maria for six days Monday, Tuesday, Wednesday, Thursday, Friday, Saturday with twenty-four workers at a rate of three soldi for the work - totaling three libre and twelve soldi.

Ten senior laborers for the aforesaid days with forty one workers at a rate of two soldi for the work - totaling three libre and two soldi.

Six junior laborers for the aforesaid days with thirty-two workers at a rate of sixteen denari and twelve denari for the work - totaling thirty-nine soldi.

Total-twenty-seven libre, two soldi and seven denarii.

On nineteen posts of wood for said work on Santa Maria in the Towers - thirty three soldi and three denarii.

On twelve panels of wood for the roof of Santa Maria in the Towers at a rate of three soldi and nine denarii for however much-forty-five soldi..

On one lime-kiln including travertine, wood and cooking - three libre and sixteen soldi.

On one thousand little panels for the roof of the same Santa Maria in the Towers - five libre and fifteen soldi.

On a half hundredweight (dimidio centenario) of pozzolana for said work-twenttwo soldi.

On two thousand little nails (acutis parvis) for the same work - forty soldi and ten denarii.

On twenty large spikes (acutis grossis) for the same work—eight soldi.

On twenty hundredweight (centonariis) of studs (scarponis) for the same work at a rate of four soldi per hundred-weight-four libre.

On eggs to blend colors to paint panels on the same façade — thirty denarii. ${ }^{58}$

\footnotetext{
${ }^{58}$ Maurice Prou, Compte de la Maison de l'Aumone de Sainte-Pierre de Rome (Paris: Libraire Ancienne Honoré Champion, 1918), 79-81. The original Latin entry:

Hic continentur expense laborariorum ecclesie beati Petri ejusdem anni M. CC. LXXXV. In primis, in una caula ferea posita ad fontem Paradisi-II s.

Die dominico XXII mensis julii, V magistris muratoribus qui steterunt ad laborandum et murandum frontispicium sancta Marie in turribus, pro VI diebus preteritis cum XXII operibus, ad rationem III s. pro opere-III lib. et VI s.
} 
This account, despite uncertainty regarding some of the required materials, tells us that during the month of July 1285 , for a period of six days, five master masons, nine master carpenters, and one hundred and forty-two other laborers worked on repairs to the gatehouse. During the following month, for a period of six days, presumably the same five master masons and one hundred and thirteen other laborers continued work on the gatehouse. They were engaged in work on the façade (which one of the two is not specified, perhaps both eastern and western) and on the roof. That the master carpenters were only engaged during the first month indicates that the primary work being done was on the masonry of the structure. The list of expenses for materials shows that the work, in addition to the masonry and carpentry, included painting on the façade. It could be that this painting was not of a highly skilled nature because no painters are listed among the workers. There is no mention of expenditures on bricks, but there is for concrete -

Item, VIIII manualibus pro predictis diebus ad idem opus sum XLVIII operibus, ad rationem II s. et XX d. pro opere-IIII lib. V s. et VIII d.

Item tribus aliis manualibus, pro predictis diebus cum XV operibus, ad rationem XV d. pro opere-XVIII s. et IX $d$.

Item, eodem die, VIIII magistris de lignamine, ad secandum tabulas et ad faciendum mutellos positos in ipso frontispicio pro predictis diebus, cum XLV operibus, ad rationem XL d. et III s. pro opere-VII lib. IIII s. et VIII d.

Item, VII manualibus pro predictis diebus cum XXXV operibus, ad rationem II s. XII d. et VI d. pro opere-XXXII s. et VId.

Die dominico, V mensis augusti, V magistris muratoribus ad dictum opus Sancte Marie pro VI diebus preteritis, scilicet die lune, die martis, die mercurii, die jovis, die veneris et die sabbati cum XXIIII operibus, ad rationem III s. pro opere-III lib. et XII s.

Item, X manualibus majoribus, pro predictis diebus, cum XXXIIII operibus, ad rationem XVI $d$. et XII d. pro opere-IIII lib. et II s.

Item, VI manualibus minoribus, pro predictis diebus, cum XXXIIII operibus, ad rationem XVI d. et XII d pro opere-XXXVIIII s.

Summa: XXVII lib. II s. et VII d.

Item, in XVIIII palumbellis de lingo pro dicto opere Sancte Marie in turribus-XXXIII s. et III d.

Item, in XII planis de lingo pro tecto Sancte Marie in turribus, ad rationem III s. et VIIII d. per quamlibet-XLVs.

Item, in una calcaria calcis, computatis tiburtina, lignis et coctura-III lib. et XVI s.

Item, in uno miliare de tabulellis pro tecto ipsius Sancte Marie in turribus-V lib. et XV s.

Item, in dimidia centonario puteolane pro dicto opere-XXIII s.

Item, in duobus miliariis de acutis parvis pro ipso opere-XL s. et Xd.

Item, in duobus decenis de acutis grossis pro ipso opere-VIII s.

Item, in XX centonariis de acuti scarponis pro ipso opere-IIII lib.

Item, in ovis ad distemperandum colores ad depignendum tabuillas in ipso frontispicio-XXX $d$. 
the slaked lime and pozzolana was mixed. This could mean either that bricks were available to be re-used, as spolia, or that the concrete was simply for the facing of the masonry and not for mortar.

Without further conjecture about the precise nature of the repairs, such a laborintensive endeavor concentrated on the masonry fabric of the building suggests a renovation that went beyond the regular upkeep required to maintain a comparatively small structure against the gradual degenerative processes of time and weather, exacerbated by the fact that there had been prior non-natural damage to the gatehouse. ${ }^{59}$ This was not a casual touch-up project; it was integral. ${ }^{60}$ Possibly, the removal of all evidence of the ruin that the gatehouse sustained due to the fire of 1167 would necessitate such a rebuilding effort. As alluded to above, elimination of this reminder of imperial aggression against the papacy in 1285 would make sense because with Conradin's death in 1268, Frederick Barbarossa's legitimate descendants and the Hohenstaufen dynasty, with whom the papacy had been in prolonged conflict, were no more.

This information furnishes one potential answer to the first question posed above in this chapter: Giotto's Navicella may have been commissioned as the culminating stage in the restoration of the gatehouse and as the replacement for the mosaic burned in 1167. With more certainty it can be said that his mosaic was not simply a repair to the

\footnotetext{
${ }^{59}$ Repairing the entire roof of Old St. Peter's basilica took a little more than two years (1339-1341, under Pope Benedict XII). This much larger and far more complex reconstruction project continued for just 50 times longer than the work on the gatehouse. See for the date of Pope Benedict XII's repairs to the roof of Old St. Peter's: Michele Cerrati, "Il tetto della Basilica Vaticana rifatto per opera di Benedetto XII" in Mélanges d'archéologie et d'histoire, 35 (1915): 83.

${ }^{60}$ Further attesting to the necessity for the immediate repair-work on the gatehouse is Julian Gardner's statement that "[Pope Honorius IV] Savelli (1285-87), a member of a second-rank family from the Campagna nobility, aimed at the consolidation and extension of his family's power by the acquisition of land: his Roman patronage is negligible." The work on the gatehouse being an exception to Gardner's assessment of Pope Honorius IV's lack of Roman patronage during his brief pontificate gives good reason to believe that the gatehouse work was at that time deemed absolutely necessary. Julian Gardner, "The Stephaneschi Altarpiece: A Reconsideration" in Journal of the Warburg and Courtald Institutes, 37 (1974): 65.
} 
preceding mural, but, thanks to the evidence for the reworking of the masonry of the structure in 1285 (which would have required the removal of any mosaic covering the façade), clearly it must have been an entirely new mural.

Another possibility to consider, however, is that, despite the lacuna in the historical record, the atrium-facing gatehouse mosaic was repaired soon after the siege of Frederick Barbarossa. Notwithstanding the anti-pope Paschal III's coronation of the Emperor Barbarossa and his wife in Saint Peter's shortly after its surrender by Alexander III, at which time the burned gatehouse could not have been repaired, four coronations took place at the basilica from 1167 to $1285 .{ }^{61}$ Even Barbarossa's own grandson, Frederick II, and his wife Constance were crowned in the basilica in 1220 by Pope Honorius III.

The importance of the gatehouse and the atrium in the ritual of imperial coronation was tremendous. After a procession westward from the Tiber River and across the piazza, the soon-to-be crowned emperor would meet the pope at the top of the stairs leading to the gatehouse. There the sovereign would ceremoniously kiss the feet of the pope, and they would proceed into the entrance of the church of Santa Maria in Turri where the soon-to-be emperor would swear fealty to the pope and the church. The pope and his retinue of cardinals would then depart into the basilica, while in the gatehouse the future emperor was inducted into the chapter of the canons of Saint Peter's and thereupon accompanied by his fellow canons across the atrium to a stone on the atrium's pavement known as the rota porfirea. While the sovereign stood there, a prayer was recited by the

\footnotetext{
${ }^{61}$ This is impossible because Barbarossa's siege of St. Peter's took place on July 29, 1167 and the coronation took place the very next day on July 30, 1167. Ottonis Morenae et continuatorum historia Frederici I, ed. Ferdinand Güterbock, 204-205.
} 
Cardinal Bishop of Alba, and they then proceeded into the basilica for the culmination of the coronation. ${ }^{62}$

During the coronations of Henry VI and Frederick II, the fire damage caused by their respective father and grandfather in 1167 could hardly go unnoticed. It is therefore possible that the evidence of the damage was removed prior to these events, respectively in 1191 and 1220. Or, it could be that the damaged gatehouse was left as a reminder of the oath that was so flagrantly broken by their Hohenstauffen predecessor, yet which they were both likewise to solemnly swear. For the former possibility we would have to suppose that there was another reason for the large-scale work on the gatehouse in 1285 , but that this work provided the impetus for Giotto's commission to make anew the gatehouse mosaic remains highly probable.

The earliest year that has been proposed for Giotto's creation of the Navicella mosaic is 1298. For example, Georg Max Zimmerman writing in 1899 stated: "Wie wir aus sicherer Quelle wissen, arbeitete Giotto das Mosaik im Jahre 1298." (As we know from a sure source, Giotto worked on the mosaic in the year 1298. ${ }^{63}$ In fact, this date was accepted as having been authoritatively determined until Lionello Venturi published the article "La Data dell'attività romana di Giotto" in $1918 .{ }^{64}$ For Zimmerman, like other scholars prior to Venturi's publication, had Filippo Baldinucci as his reliable source.

Baldinucci wrote his Notizie dei Professori del Disegno and dedicated it to Cosimo III, Grand Duke of Tuscany in 1681 . Clearly this book is not a primary source on the date of Giotto's work in St. Peter's, but it is the exact manner, as we shall see, in

\footnotetext{
${ }^{62}$ This description paraphrases De Blauww, Cultus et Décor, vol. 2, 733-5.

${ }^{63}$ Georg Max Zimmerman, Giotto und die Kunst Italiens im Mittelalter (Leipzig: Seemann, 1899) 389.

${ }^{64}$ Lionello Venturi, "La Data dell'attività romana di Giotto" in L'Arte, vol. 21 (1918): 229-235.
} 
which he gives his information that inspires confidence in the reliability of the date that he supplies for the mosaic.

Baldinucci's Notizie in its form and subject matter is comparable to Vasari's famous Lives of the Artists, except it is written in a more scholarly style with citations of sources, and he often attempts to correct or improve upon Vasari's Lives. That critical aspect of the work is actually the context for the passage in question. At the very beginning of his biography of Giotto, Baldinucci calls into question Vasari's statement about the date of birth of Giotto. Here he supplies some very specific details about his primary source for the Navicella's date:

Il Vasari, o pure lo stampatore della sua storia, pare che errasse nel dire l'anno 1276 esser seguito il natale di quest'artefice [Giotto], tanto più che è chiaro appresso di me non aver egli avuta notizia di quanto io trovo di lui, e d'alcune circostanze dell'opere sue fatte nella città di Roma, come ora son per dire; Nell'archivio di S. Pietro in Vaticano, in un libro intitolato Martirologio, foglio 83, si trova la seguente memoria, venuta a mia cognizione prima per nota ritrovata nella mai a bastanza celebrata libreria de'manoscritti originali, e spogli del già Carlo della nobilissima famiglia degli Strozzi senator fiorentino, poi per riscontro avutone della medesima città di Roma, e finalmente per aver trovato essere stata accennata dal Torrigio nel suo libro delle Sacre Grotte Vaticane, al capitolo 5, siccome da altri moderni autori

(Vasari, or also the printer of his history, appears to have erred in saying the year 1276 was the birth of this artist [Giotto], so much more that it is clear now to me I have not had news of how much I find of him, and of some circumstances of the works he made in the city of Rome. As now I will tell; in the archive of St. Peter's in the Vatican, in a book entitled Martyrology, page 83, is found the following notice, that came to my knowledge first through a note rediscovered in the nevercelebrated-enough library of original manuscripts, and pages of the late Carlo of the most noble family of the Strozzi, Florentine senator, then through having checked again in that same city of Rome, and finally to have found noted by Torrigio in his book of the Sacred Vatican Grottoes, at Chapter 5, as from other modern authors) ${ }^{65}$

\footnotetext{
${ }^{65}$ Filippo Baldinucci, Notizie dei Professori del Disegno (Firenze: V. Batelli e Compagni, 1845), vol. 1, 103-4.
} 
In this statement regarding his primary source of information and the circumstances in which he found it, Baldinucci informs us that he was led to a Martyrology in the archive of Saint Peter's through a note he discovered in the Strozzi library in Florence. He then confirmed the information from that note in Rome, presumably by going to the archives of Saint Peter's where the note in the Strozzi library led him. And then he found the same information from his primary source in the work of Francesco Maria Torrigio and some other modern authors.

What makes Baldinucci's account so credible is that, in the first place, he is not trying to establish the date of Giotto's Navicella, which he goes on to pinpoint as 1298; he is critiquing Vasari about the date he gives for Giotto's birth. The date that he discovered for Giotto's Navicella simply led him to question Vasari's information, and as he notes, Vasari did not know when Giotto created the Navicella. Baldinucci implies that if Vasari had the information that he now does, he may have reconsidered the year 1276 for Giotto's birth. In other words, Baldinucci is reporting the date of the Navicella disinterestedly; what he is concerned with is establishing the correct date for Giotto's birth and that is, for his purpose, the major significance of his information on the date for the Navicella.

The second aspect of the passage which rings true is the extreme amount of detail, both circumstantial and bibliographical, that he supplies for his findings. He gives a book title, a page number, and a place where the book is found, and he tells how he found that book. With all of these details it is easy to see why Baldinucci was considered for so long to be trustworthy. But if we check in Torrigio's work, Le Sacre Grotte Vaticane, where Baldinucci claims to have found this same record of Giotto's work in Rome, the 
date of 1298 is not given - much of the same wording and information, but no date. ${ }^{66}$ This is due to the fact that Torrigio's source must have been the Liber anniversorum (Libro antiquo benefactorum) from which the Martyrology consulted by Baldinucci quotes, but the Liber anniversorum does not give a date for the creation of the Navicella.

Venturi, however, theorized that Baldinucci actually relied on an earlier "modern" author for his information on the primary source. That author was Giulio Mancini, a Siena-born doctor and art lover writing in Rome, at the Hospital of the Holy Spirit, around 1620. His Considerazioni sulla pittura contains a section entitled "Considerazioni intorno ad alcune cose tralasciate o non ben dette dal Vasari." Here we find Mancini also disagreeing with Vasari about the date of Giotto's birth. Among the contradictions and impossibilities that he finds regarding this birthdate he states: " $e$ questo è quello che si vede nell'Archivio di S. Pietro di Roma, in un libro detto Il Martirologio, $f .89$, con queste parole" (and this is that which is seen in the Archive of St. Peter's in Rome, in a book called the Martyrology, page 89, with these words). ${ }^{67}$ What follows from Mancini is, with a few notable discrepancies discussed below, repeated verbatim in Baldinucci.

While the same context for introducing the primary source relating to the date of Giotto’s Navicella may make it very compelling to suggest Baldinucci’s reliance on

\footnotetext{
${ }^{66}$ Francesco Maria Torrigio, Le Sacre Grotte Vaticane (Roma: appresso Iacomo Facciotti, 1635), parts 1 and 2, 162-3. This reference comes from parte seconda: capitolo 2, not capitolo 5 as stated by Baldinucci. The crucial missing information of the date and the incorrect citation of the chapter number are suspicious. Is it possible that Baldinucci consulted a manuscript of Torrigio with different pagination/chapter divisions and that contained the date of 1298 for Stefaneschi's commission? Le Sacre Grotte Vaticane survives in several editions $(1618,1635$, and 1639). From available editions, Torrigio's source was the Liber anniversorum, discussed below, which was quoted in full in the Martyrology cited by Baldinucci. Unless, as Baldinucci claimed, Torrigio in some edition of his work had fully reported the same information as Baldinucci does in his Notizie, including the date of 1298 for the commission.

${ }^{67}$ Giulio Mancini, Considerazioni sulla pittura, ed. Lionello Venturi (Roma: Accademia Nazionale dei Lincei, 1956), vol. 1, 170.
} 
Mancini for the citation, it must be admitted that this need not necessarily be the case. If both authors independently came to discover a primary source providing the date for Giotto's work on the Navicella, and they both were writing biographical accounts of the artist, they both might be led to record that same evidence in the same context. There are very few primary sources with definite dates for the life of Giotto, so if an author found a definite date that logically countered a proposed date, that author might necessarily cite the same source in the same context as another author, but the one need not have copied from the other.

Although the context of the argument is the same in both authors for quoting the Martyrology, there are noteworthy differences. As mentioned above, Baldinucci gives a lengthy preface to the citation about where and how he found his primary source. Mancini simply gives the place, book title, and page number, but not exactly the same as Baldinucci. Baldinucci states, "Nell'archivio di S. Pietro in Vaticano, in un libro intitolato Martirologio, foglio 83." Mancini states, “nell'Archivio di S. Pietro di Roma, in un libro detto Il Martirologio, f. 89."

If Baldinucci were copying directly from a source (Mancini), he might be expected to copy it precisely, especially in providing an important historical reference like the number of the folio. And, why would he not state his reliance upon Mancini if it were the case; he does not claim to be the only writer to have discovered this information? He states, inaccurately, that it can also be found in Torrigio, who like Mancini wrote fifty and more years earlier. Considering all these factors, there is certainly room to doubt Venturi's theory that Baldinucci relied upon Mancini and not the primary source that he claims. Venturi himself seems to have rethought his earlier claim 
that the information was fabricated when, discussing the passage in the 1957 supplement to his edition of Mancini's Considerazione, he states, "onde è certo che Mancini [i.e., himself] dovette copiare un codice in cui il testo era più ampio. ${ }^{, 68}$ This concession permits skepticism about the authenticity of the Martyrology from which Mancini "must have copied," but disavows Venturi's previous theory, argued in his 1918 article, that Mancini invented the citation.

In fact, comparing the direct quotations drawn from the Martyrology by both Mancini and Badinucci word for word, there are some discrepancies. Here is Mancini's Latin quotation in full with the variances of Baldinucci's quotation in brackets, excepting some minor differences in spelling and abbreviation:

Jacobus Gaetani de Stephanescis Diac. Card. S. Georgij, Matthei Ursini Cardinalis Archi. S. Petri [Bonifacii Papae VIII Nepos] Nepos, Nicolai PP. 3ij Pronepos, ex [et] Rotae Auditore et Sacrae Basilicae Vaticane Canonico a Bonifatio VIII de Anno 1295 Cardinalis [Canonicus] declaratus, de Vaticana Basilica cuius canonicatum quandiu vixit retinuit optime meritus, Naviculam $S$. Petri de Anno 1298 eleganti musaico faciendam curavit per manus Jotti celeberrimi pictoris. Pro quo opera florenos 2200 persolvit, ut ex libro antiquo Benefactorum fo. 87 sub his verbis

(Jacopo Gaetani Stefaneschi Deacon Cardinal of St. George, nephew of Matteo Orsini Cardinal archpriest of St. Peter's [Nephew of Pope Boniface VIII], grandnephew of Pope Nicholas III, and Auditor of the Wheel and Canon of the Sacred Vatican Basilica declared a Cardinal [Canon] by Boniface VIII in the Year 1295 , who as a canon while he lived retained the most merit for the Vatican Basilica, the Navicella of St. Peter of the Year 1298 an elegant mosaic made with care through the hand of Giotto the most celebrated painter. For which work he paid 2200 florens, so from the book of ancient Benefactors page 87 under these words) ${ }^{69}$

Both Mancini and Baldinucci continue their quotation from the Martyrology from there, but there are no more major differences between them.

\footnotetext{
${ }^{68}$ Mancini, Considerazione, vol. 2, 66-67, n. 570.

${ }^{69}$ Mancini, Considerazione, vol. 1, 170 and Baldinucci, Notizie, vol. 1, 103-4.
} 
The two notable discrepancies in this quotation from the Martyrology bear significantly upon Venturi's argument against the authenticity of either Baldinucci's or Mancini's reference, both of which Venturi regarded as apocryphal. Venturi: "Le tre notizie che il passo del Mancini trae da fonte ancora ignota sono: 1. lo Stephaneschi e nipote di Bonifacio VIII; 2. L'anno 1295 fu quello del suo canonicato; 3. L'anno 1298 fu quello della commissione della Navicella." (The three notices that the passage of Mancini derives from sources now unknown are: 1. Stefaneschi is the nephew of Boniface VIII; 2. He became a canon in the year $1295 ; 3$. The year 1298 was that of the commission of the Navicella. $)^{70}$

Of these three points, only the date of 1298 for the Navicella is actually given in both Baldinucci and Mancini. Contrary to Venturi's statement above, the information that Stefaneschi is the nephew of Boniface VIII and that Stefaneschi became a canon in 1295 is found only in Baldinucci, whom Venturi regards to be dependent upon Mancini. It is through Venturi's tracing of Mancini's sources for these two points of information (found only in Baldinucci) that Venturi arrives at his conclusion that the date of 1298 was invented by Mancini and copied by Baldinucci. With this confusion of authors in mind, Venturi's argument regarding Mancini's supposed formulation of the date of 1298 for the Navicella must be considered invalid. His argument could apply only to the reference in Baldinucci, for it alone supplies the crucial information in question, and, on the basis of the two prominent differences in the information Baldinucci provides, apparently independently from Mancini. Mancini's quotation from the Martyrology then gives no questionable information other than the date of the Navicella. There is no likelihood that both writers independently invented the same year for Giotto's work.

\footnotetext{
${ }^{70}$ Venturi, “La Data dell'attività Romana di Giotto,” 233.
} 
The explanation for this discrepancy in the quotations cited by Mancini and Baldinucci in their respective texts could be that they were referring to two different recensions of the Martyrology manuscript. Already by the fifteenth century there existed two different recensions of the Liber anniversorum in the Vatican Archives from which the Martyrology quoted. ${ }^{71}$ First, the authors supply two different folio numbers for where the quotation can be found. Second, they give the part of the quote not drawn from the Liber anniversorum, differently, too. The differences in the quotations are rather significant as well, because they supply different biographical details about Cardinal Stefaneschi, so it cannot be that Mancini and Baldinucci merely read the handwriting of the manuscript differently. If it is accepted that Baldinucci did not copy Mancini, and he certainly did not copy him exactly, then it is only the reliability of the Martyrology that is in question.

But a strong confirmation of the Martyrology's reliability can be found earlier in Baldinucci's Notizie where he references the same source. "In un Ricordo nell'antichissimo Libro de'benefattori della Vaticana Basilica, fog. 87, del quale anche vien fatto menzione nel libro intitolato Martirologio, esistente nell'Archivio di s. Pietro in Vaticano, fog. 83, citato da più autori, quale noi pure porteremo intero nella vita di Giotto, si legge fra l'altre cose." (In a record in the most ancient Book of Benefactors of the Vatican Basilica, page 87, some of which also came to be mentioned in the book entitled Martyrology, existing in the Archive of St. Peter's in the Vatican, page 83, cited by many authors, which we also will bring entirely into the life of Giotto, to be read

\footnotetext{
${ }^{71}$ Pietro Egidi, Necrologi e Libri Affini della Provincia Romana (Roma: Nella Sede dell'istituto Palazzo dei Lincei, 1908), vol. 1, 167-173.
} 
among other things. $)^{72}$ Here Baldinucci acknowledges that his source for the date of the Navicella (the Martyrology) also quotes from another manuscript in the Vatican archives: the Liber anniversorum. Venturi, in his article, affirms - in agreement with the quotations of Baldinucci and Mancini-that it is actually on page 87 of what the quote refers to as the Libro de'benefattori della Vaticana Basilica that we find the entry for Jacopo Stefaneschi and for his patronage of St. Peter's basilica. ${ }^{73}$

If we are to assume that, although we do not have the Martyrology quoted by both Mancini and Baldinucci, it is an authentic source from the Vatican Archives of their time, then this Martyrology correctly referenced and cited the Liber anniversorum that is extant, giving the exact wording and page number which can be checked today. The Martyrology, however, additionally contained the crucial date of 1298 for Stefaneschi's commissioning of Giotto's Navicella, and, if one is to doubt the Martyrology's accuracy, it is the skeptic who would have to bear the burden of proof. It is evidently for establishing the commission's date, the date of his attaining the cardinalate or becoming a canon of St. Peter's (perhaps in the same year), and for establishing his illustrious family relations that Cardinal Stefaneschi's entry in the Martyrology was composed, because it is this information that is absent from his obituary in the Liber anniversorum.

Through an examination of internal evidence within the list of Cardinal Stefaneschi's bequeathed properties, Irene Hueck determined a date of 1361-62 for the composition of the Liber anniversorum in the Vatican Archives. ${ }^{74}$ Thus it was composed about twenty years after the death of Stefaneschi in 1342 and chronologically relatively

\footnotetext{
${ }^{72}$ Baldinucci, Notizie, vol. 1, 41.

${ }^{73}$ Venturi, "La data dell'attività Romana di Giotto," 232 and again 233, n. 4.

${ }^{74}$ Irene Hueck, "Das Datum des Nekrologs für Kardinal Jacopo Stefaneschi im Martyrologium der Vatikanischen Basilika" in Mitteilungen des Kunsthistorischen Institutes in Florenz, vol. 21, n. 2 (1977): 219-20.
} 
closely to the information which it reports. This also gives a date of 1362 or later for the composition of the Martyrology, which cites the Liber Anniversorum. The date of 1298 given by Mancini and Baldinucci for the commissioning of the Navicella is not ruled out by any evidence or argument that has heretofore been produced, and it must be further analyzed to find what support or contradiction there is for such an early date. 


\section{CHAPTER IV}

\section{TOWARDS THE HISTORY OF GIOTTO”S NAVICELLA}

The year 1298 as the date for Giotto's fulfillment of Cardinal Stefaneschi's commission to make the Navicella mosaic is circumstantially supported by the fact that the 1290s was a prolific decade of mosaic mural-making activity for the churches of Rome. Jacopo Torriti completed his work in the apse of St. John Lateran in 1292 and the apse of Santa Maria Maggiore in 1296. Pietro Cavallini worked on the cycle of the Life of the Virgin in Santa Maria in Trastevere from 1296-1300 under the patronage of Bertoldo Stefaneschi, brother of Cardinal Jacopo Stefaneschi. If Giotto had been working with both of these artists previously on the frescoes of San Francesco in Assisi, as has been proposed, it would not be surprising to find him next learning the art of mosaic from them and then accepting his own commission from Cardinal Stefaneschi. ${ }^{75}$

Considering the date of 1298 for the work, there are two very early frescoes potentially based upon Giotto's Navicella. The earlier of the two, a fresco of St. Peter

\footnotetext{
${ }^{75}$ The exact nature of Giotto's involvement with the physical creation of the Navicella mosaic is unknown, especially due to his not having worked in the medium of mosaic at any other time in his career. D'Arcais, Giotto, 244, states: "It is quite probable, and by now accepted almost unanimously by scholars, that Giotto traveled to Rome to create the cartoon for the great mosaic called the Navicella..." A more detailed consideration of the matter is to be found in M. Andaloro, "Giotto tradotto" in Frammenti di memoria, M. Andaloro, S. Maddalo, M. Miglio eds., 17-35, especially 30-31. In this chapter Andaloro, based upon her knowledge of Cimabue's role in the creation of the mosaics of the Duomo in Pisa, posits a role for Giotto in the creation of the Navicella mosaic as "pictor parietarius nei riguardi del mosaico, nelle vesti di una figura familiare alle esperienze contemporanee, com'è il regista, e perciò da immaginare costantemente presente in cantiere, sui ponteggi, a seguire e forse ad eseguire le stesure ad affresco sulla malta d'allettamento del disegno preparatorio e delle campiture colorate e comunque in stretto e contiguo rapporti con la comunità dei mosaicisti." This level of involvement would help to explain the reported cost for Cardinal Stefaneschi's commission to Giotto of 2200 florins much better than simply the artist's creation of a cartoon.
} 
being rescued from the Sea of Galilee by Christ in the basilica of San Piero a Grado in Pisa, has never been posited as being based upon Giotto's mosaic (Figure 13). ${ }^{76}$ The later one is also a fresco representing the same Biblical narrative in the church of St. Peter the Younger in Strasbourg, France (Figure 14), that is more certainly based upon Giotto's Navicella.

Regarding the fresco in San Piero a Grado, Jens Wollesen stated that the artwork provided a terminus post quem for Giotto's Navicella because the artist Deodato Orlandi had no knowledge of Giotto's composition, which surely would have served as his model had it existed at that time, and that the fresco was instead based upon the mosaic on the gatehouse of St. Peter's that preceded Giotto's. ${ }^{77}$ If Wollesen's statement were true, then it would confirm that Giotto's mosaic repeated the narrative subject matter of its predecessor, which was also an illustration of the same event from the Gospel according to St. Matthew, but the situation is not so settled. His analysis presumed that Giotto's Navicella resembled the composition of the Beatrizet copper etching and without taking into account the evidence of the Musée Condé drawing. This alternative possibility is worthy of our consideration.

San Piero a Grado in Pisa is a basilica near the shore of the Tyrrhenian Sea that commemorates the site where St. Peter, after having disembarked on his mission to evangelize Italy, is said to have celebrated his first mass with the local converts to Christianity. The documentary and physical evidence shows that the fresco cycle of the life of St. Peter in San Piero a Grado was commissioned by Benedetto Gaetani following

\footnotetext{
${ }^{76}$ The reason for the reference to steps in the name of the basilica came to light in excavations begun in 1998 - there were stairs that led up to the basilica from the southern branch of the Arno delta. Stefano Sodi and Mariagiulia Burresi, La Basilica di San Piero a Grado (Pisa: Edizioni ETS, 2010), 6-7.

${ }^{77}$ Jens Wollesen, Die Fresken von San Piero a Grado bei Pisa (Bad Oeynhausen: A. Theine, 1977), 19.
} 
the declaration by his uncle, Pope Boniface VIII, of the first Jubilee Year for the Church in $1300 .{ }^{78}$ This date leaves open the possibility that Orlandi could have drawn upon Giotto's mosaic for his composition. At least part of the Pisan cycle is unquestionably based upon the cycle of the same subject in the atrium of Old St. Peter's. Giacomo Grimaldi made drawings of the frescos in the western portico of Old St. Peter's atrium which, when compared to those of the same subject by Orlandi in Pisa, show almost exactly the same compositions. (Compare as a representative example Figures 15 and 16.)

These frescoes once existing in Old St. Peter's atrium have been dated to circa 1262 or the late 1270 's from the analysis of a fragment preserved today in the grottoes beneath St. Peter's convincingly identified as having once belonged to the cycle. ${ }^{79}$ Their subject matter illustrates events that took place after the Acts of the Apostles as compiled and recounted by Jacobus de Voragine, the bishop of Genoa, in his Golden Legend (ca. 1275). In San Piero a Grado, the frescoes likewise drawn from the Golden Legend are found on the north wall of the nave. On the south wall are scenes from St. Peter's life as recorded in the Gospels and the Acts of the Apostles. Unlike the frescoes of St. Peter's later life on the north wall, those on the south wall do not have established precedents in the atrium of Old St. Peter's. However, it has been supposed that the entire fresco cycle was based upon precedents in Old St. Peter's.

\footnotetext{
${ }^{78}$ The presence of the Gaetani coat of arms on a lamp indicates the family's patronage, while Pope Boniface VIII appointed his nephew Benedetto Gaetani provost of San Piero a Grado in 1300. See Pietro D'Achiardi, "Gli Affreschi di San Piero a Grado presso Pisa e quelli già esistenti nel portico della Basilica Vaticana" in Atti del Congresso Internazionale di Scienze Storiche, vol. 7, n. 4 (1915): 269.

${ }^{79}$ Antonio Muñoz was the first to link the extant fragments in the grottoes with the lost frescoes from Old St. Peter's portico and supported the earlier date in Antonio Muñoz, "Le Pitture del portico della Vecchia Basilica Vaticana e la loro datazione" in Nuovo bollettino di archeologia cristiana, vol. 19 (1913): 175180. Wollesen, Die Fresken von San Piero a Grado, 107-108, argues for the later date. Regardless of which date is accepted, the frescoes existed in the atrium, to be copied later by Orlandi in the nave of San Piero a Grado, decades prior to the patronage of Benedetto Gaetani.
} 
Supplementing the graphic evidence of the frescoes in Old St. Peter's atrium recorded by Grimaldi, we also have his drawings recording the appearance of the nave walls of Old St. Peter's. Both the north and south walls of Old St. Peter's nave featured a frieze of papal busts in roundels recording the succession of popes. This same ornament was featured in the spandrels of the nave arcade in San Piero a Grado. With the overall structure of the fresco cycle in the nave of San Piero a Grado strongly paralleling elements of the ornamentation of Old St. Peter's, it is likely that the scenes on the south wall in Pisa were also drawn from Old St. Peter's. Such a relationship has been posited because the south nave wall of Old St. Peter's featured frescoes based upon the New Testament, of which Grimaldi made drawings but most of which he was unable to reproduce graphically due to their being too darkened in his time. The exception to the theory that the Gospel scenes featuring St. Peter on the south wall of the nave in Pisa were drawn from the frescoes on the south wall of Old St. Peter's nave would be made for the Navicella scene, which is thought to have been based on the mosaic of the gatehouse in the atrium.

But there is a better possibility that the precedents for all the scenes in San Piero a Grado were to be found in the atrium of Old St. Peter's. By the time that Giacomo Grimaldi made his drawings of the atrium fresco cycle, both the north and south porticoes of the atrium had been demolished and replaced with other buildings. ${ }^{80}$ This situation prompted Grimaldi to state as a matter of fact: "Atrium enim basilicae Vaticanae, ut planta in fine huius libri apparet, quadriporticu columnato cinctum erat; et consequenter aliis beati Petri historiis supradictis similibus porticus ipsa in fronte exornata." (The

\footnotetext{
${ }^{80}$ The removal of the lateral (southern and northern) porticoes is associated with the return of Pope Martin V to Rome in 1420: D'Achiardi, "Gli Affreschi di San Piero a Grado presso Pisa," 248.
} 
atrium of the Vatican basilica, the plan appears in the end of this book, was enclosed with a colonnaded quadriportico; and consequently other stories of St. Peter similarly adorned the front of the above-said portico. $)^{81}$ It would be much more consistent for the scheme of frescoes in San Piero a Grado if the entire narrative cycle of the Life of St. Peter had been drawn from the frescoes of the same subject in the atrium of Old St. Peter's rather than having been piecemeal drawn from various locations in the basilica. Also in favor of this possibility is the fact that all definitely established precedents for the narrative frescoes in San Piero a Grado, and the only other proposed precedent — the gatehouse mosaic - were in the atrium. The inclusion of scenes from the life of St. Paul in the frescoes of San Piero a Grado practically assures that they were modelled upon the atrium scenes, for the frescoes in Old St. Peter's atrium included scenes from the life of St. Paul due to the presence of his relics at the site, while the basilica of San Piero a Grado has no such connection with St. Paul. Therefore these scenes of St. Paul were included strictly because the fresco scheme of San Piero a Grado was modelled upon that of the forecourt of Old St. Peter's.

Since Orlandi produced such precise copies of the atrium frescoes illustrating scenes from the Golden Legend, as recorded by Grimaldi, it might be expected that Orlandi's copy of the Navicella scene would be precise as well. However, we have already established that there is uncertainty regarding the exact appearance of Giotto's Navicella, and we have even less evidence with which to reconstruct the gatehouse mosaic that existed prior to Giotto's work. Further complicating the attempt to compare the Pisan fresco with Giotto's Navicella or its predecessor on the gatehouse is the fresco's

\footnotetext{
${ }^{81}$ Reto Niggl ed., Giacomo Grimaldi: Descrizione della basilica antica di S. Pietro in Vaticano (Roma: Biblioteca Apostolica Vaticana, 1972), 179.
} 
poor state of preservation, with only about half of the image extant. Also, unlike Orlandi's work, our two candidates for the reconstruction of Giotto's composition, the Musée Condé drawing and the Beatrizet etching are without color. This problem is checked somewhat by comparison with Francesco Berretta's canvas painted copy of the mosaic which was ordered in the seventeenth-century to reproduce the color and scale of the remains of the gatehouse mosaic exactly (Figure 17). ${ }^{82}$

Additionally impacting a comparison between the gatehouse mosaic and the fresco in San Piero a Grado is the format of the composition. Comparing Grimaldi's drawing of the Dream of Constantine from the atrium of Old St. Peter's with the fresco of the same subject in San Piero a Grado, it is clear that the slight change in shape did affect the composition of the reproduction. Grimaldi shows the fresco in the atrium to have an almost square format, only a bit taller than wide. The format of the Dream of Constantine fresco in San Piero a Grado is proportionately taller and more rectangular, so that the fictive architecture in the background has been extended vertically to fill out the frame.

The disparity between the formats of the gatehouse mosaic and the Pisan fresco is far greater. Whether we look at the Musée Condé drawing, the Beatrizet etching, or Paeseler's reconstruction of the gatehouse mosaic, it is evident that the gatehouse mosaic was a horizontal rectangle with a ratio of height to width of about $2: 3$. The fresco of

\footnotetext{
${ }^{82}$ This painted copy of the Navicella was eventually installed in a lunette in the Capuchin church of Santa Maria della Concezione in Rome and left with an inscription dedicated to Pope Urban VIII who commissioned the copy. The inscription has been treated as evidence for the dating of Giotto's mosaic because it did apparently make an assertion in that regard. Yet even what assertion the inscription made is unclear, rendering its value as evidence null. "Während Torrigio behauptete, das Mosaik sei "ante annos 320 [before 1629 when the painting was installed in the church]" enstanden, sprach Bonanni von "ante annos 310". Zieht man ausserdem die Überlieferung Suaresius' (ante annos 300") in Betracht, so ist zu bezweifeln, ob man die Inschrift der Berretta-Kopie in ihrer dreifach unterschiedlichen Tradierung überhaupt als Argument in der Auseinandersetzung um die Datierung des Mosaiks zulassen sollte." Köhren-Jansen, Giottos Navicella, 254.
} 
Saint Peter saved from the Sea of Galilee in San Piero a Grado, like the other scenes on the south wall, is a vertical rectangle with a ratio of height to width of about 5:4. Therefore, if Orlandi were to translate the composition of the horizontally formatted mosaic image into his vertically oriented fresco, changes had to be made to the composition beyond the mere extension of the background architecture found in his Dream of Constantine copy.

To support the hypothesis that the fresco in San Piero a Grado was a copy of Giotto's Navicella mosaic, Figure 18 is a hypothetical reconstruction of some destroyed areas of the mosaic to illustrate the possibility that Orlandi's fresco is derived from Giotto's mosaic as reproduced in the Musée Condé drawing. Both reconstructed elements of the fresco, the sail and the wind demon, were reproduced from other scenes in the San Piero a Grado fresco cycle. The sail was excerpted from the scene of Saint Peter sailing to Italy, the wind demon from the Theft of the Apostles' bodies. That these visual elements were painted elsewhere in the same fresco cycle lends credibility to the reconstruction, especially for the sail, because every other boat represented by Orlandi in the fresco cycle has a sail of this design, very much like the sail seen in either the Musée Condé drawing or the Beatrizet etching of the Navicella.

With this hypothetical reconstruction the resemblance of the fresco to the Musée Condé drawing is striking. Accounting for the fact that Orlandi had to eliminate the fictive architecture and the fisherman from the left side of his composition in order to fit the altered proportions of his fresco, every other iconographic element has been reproduced. The boat inhabited by the apostles gesturing variously is shown to the left in the background. To the far right and in the foreground is the enlarged figure group of 
Christ and St. Peter. In the Pisan fresco, just as in Berretta's later color copy of the mosaic, St. Peter is depicted in both images robed in blue and gold. Also, if one attends to St. Peter's drapery, there is a close-to-exact resemblance among all three images (Orlandi's, Parri's, and Beatrizet's) in the way the figure's gold mantle covers his lower body and wraps over his left shoulder, while his extended right arm emerges from the mantle to reveal the underlying (blue) garment. Although it is not very visible in the reproduction, Köhren-Jansen notes that the Christ in Orlandi's Navicella is depicted standing frontally, as shown in the Musée Condé drawing. ${ }^{83}$

On the other hand, it is far less conceivable even in the hypothetical reconstruction that the Pisan fresco was based upon the composition displayed by the Beatrizet etching. Acknowledging that there is room in the fresco's composition for a second wind demon to the right of the sail, such a detail would not suffice to explain the enlargement of the figures of St. Peter and Christ or the clear distinction between the two figures in the foreground and the little vessel in the background. These alterations could again be attributed theoretically to the change in format, but the much stronger resemblance of the San Piero a Grado Navicella to the Musée Condé drawing than to the Beatrizet entching is apparent at a glance.

Therefore this analysis of the San Piero a Grado fresco of Saint Peter saved from the Sea of Galilee shows that it was most likely based upon either the gatehouse mosaic which preceded Giotto's Navicella, or upon Giotto's Navicella as it was pictured in the Musée Condé drawing. Given that the gatehouse mosaic was burned in 1167, and given the evidence that Giotto's mosaic had been completed prior to the execution of Orlandi's fresco cycle, the resemblance between the Pisan fresco-especially as hypothetically

\footnotetext{
${ }^{83}$ Köhren-Jansen, Giottos Navicella, 77-78.
} 
reconstructed—and the Musée Condé drawing is highly suggestive of a direct relationship between Orlandi's and Giotto's work.

Returning to the question of the date of the mosaic, the argument that Giotto painted a fresco depicting Pope Boniface VIII taking possession of the Lateran Basilica in 1297, if it is accepted, goes a considerable way toward supporting the date of 1298 for Cardinal Stefaneschi's commission of the Navicella ${ }^{84}$ First, it places Giotto in Rome at the right time, following his work in Assisi and prior to his work in Florence and Rimini. Second it dispels the doubts that might be raised about the idea of an artist of Giotto's age and experience being entrusted with such an important undertaking as the gatehouse mosaic of Saint Peter's, for if true, he had already executed and successfully completed a commission for the pope at his cathedral church. Based upon the particular shape of Boniface VIII's papal tiara in the Lateran fresco, the work was completed sometime between 1295 and 1300, after which year Boniface VIII's tiara continued to evolve from a double (recorded in an inventory of 1295) to a triple-crowned form, as shown in an intermediate state in Arnolfo di Cambio's recumbent funerary effigy of the pope (started in 1300$){ }^{85}$

Despite the lack of evidence to contradict the date of 1298 for the Navicella mosaic given by Mancini and Baldinucci, there has been a strong tendency among scholars to relate the commission with subsequent historical circumstances surrounding the papacy as both a motive for its manufacture and a major factor to consider in the interpretation of the mosaic. The three historical events with which the commission of

\footnotetext{
${ }^{84}$ Silvia Maddalo, "Bonifacio VIII e Jacopo Stefaneschi : ipotesi di lettura dell'affresco della loggia lateranense" in Studi romani: rivista bimestrale dell'Istituto di Studi Romani, vol. 31 (1983):129-150. ${ }^{85}$ Charles Mitchell, "The Lateran Fresco of Boniface VIII" in Journal of the Warburg and Courtald Institutes, vol. 14, nos. 1/2 (1951): 2.
} 
the mosaic has been linked are Pope Boniface VIII's declaration of the first Jubilee Year in February of 1300, the transfer of the papal court to Avignon in March of 1309, and the process of canonizing Pope St. Celestine V culminating in May of 1313. The great significance of the first two events for the church of Old St. Peter's and the great personal significance that all three held for Cardinal Stefaneschi make clear the temptation to view the commission and thus the interpretation of the mosaic through this historical framework. ${ }^{86}$ But there must be evidence to support any of these later dates.

In the absence of documentary evidence that provides the date for an artwork, it is common for art historians to rely on stylistic evidence, and this method of analysis has been applied to the study of Giotto's Navicella. Stylistic evidence is strongest when an artist has a well-established body of work and there is some chronological information regarding its production; then an undated work by that artist's hand can be logically fitted into the progression of the artist's evolving style and technique. The idea of dating a mosaic made by Giotto through stylistic evidence is far too problematic to be reliable. The medium is unique within Giotto's oeuvre, and the fact that only two small fragments, belonging to an unknown period, remain extant from the mosaic is an obstruction as well. Even if we are trying to use these fragments in order to make a stylistic and technical analysis of Roman mosaic-making of the period, how much can workshop practices have changed from 1298 to 1300 , if we are using this method to decide between these two dates $?^{87}$ The absurdity of establishing the date of a lost work by Giotto based upon a

\footnotetext{
${ }^{86}$ Cardinal Stefaneschi authored the Liber de centesimo sue iubileo commemorating Boniface VIII's declaration of the inaugural Jubilee Year. As a member of the Curia, Cardinal Stefaneschi left Rome and proceeded to Avignon with the papal court. He also authored the Opus metricum, which concerns, in part, his deep admiration for Pope St. Celestine V.

${ }^{87}$ Michael Viktor Schwarz, “Giotto's Navicella zwischen 'Renovatio' und 'Trecento': ein genealogischer Versuch" "in Wiener Jahrbuch fur Kunstgeschichte, 1995, 133-4. Schwarz applies a stylistic analysis of these fragments to other Roman mosaics of the period, finding stylistic parallels with Torriti's mosaics in S.
} 
stylistic analysis of the later copies made by other artists must be acknowledged as well. This standard tool of the art historian is of little use for the dating problem.

Several seventeenth-century authors attest that indeed Cardinal Stefaneschi did have in mind the many pilgrims of the Jubilee Year of 1300 when he commissioned Giotto's Navicella, but the evidence is neither primary nor unequivocal. First, Torrigio, in Le Sacre Grotte Vaticane, states of the great crowds of pilgrims to Saint Peter's that "perche quando i pellegrini arrivavano alle porte di san Pietro, per non so che di semplicità, per non dire superstitione, Avanti, che entrassero in Chiesa si voltavano verso l'Oriente, quasi adorassero il Sole" (because when the pilgrims arrive at the doors of St. Peter's, I don't know whether of simplicity or not to say superstition, advancing, upon entering in the church they turn to face the east, as if adoring the sun). ${ }^{88}$ Torrigio claims that Cardinal Stefaneschi commissioned Giotto to create the Navicella on the gatehouse to eliminate this abuse. The account runs suspiciously parallel to the abovediscussed passage by Serrano regarding Pope St. Leo the Great and his reason for the creation of the earlier gatehouse mosaic. Yet, it is entirely plausible that Cardinal Stefaneschi commissioned Giotto to create the gatehouse mosaic for the pilgrims and for the reason stated, because there may no longer have been a gatehouse mosaic in his day, following the reconstruction work of 1285 . The persistence of the pilgrims' tradition of praying towards the east despite the lack of a mosaic rings true, but the date of 1300 need not be accepted from this account.

Slightly prior to the above quotation Torrigio states as well: "Sempre la Basilica di san Pietro in Vaticano è stata da moltissimi Pellegrini visitata per le gran reliquie, et

Maria Maggiore, but Torriti's work was complete in 1296, so the parallel does not rule out the date of 1298 , but could support it if this stylistic argument is accepted.

${ }^{88}$ Francesco Maria Torrigio, Le Sacre Grotte Vaticane (Viterbo: Apresso i discepoli, 1618), 90. 
indulgenze, che vi sono state concesse da Sommi Pontefici." (Always the basilica of St. Peter in the Vatican has been visited by the very most pilgrims for the grand relics and indulgences that have been given by the high pontiff.) $)^{89}$ The implication is that the motivation of providing a sacred image for pilgrims on the gatehouse towards which they prayed upon entering the atrium would have existed for Cardinal Stefaneschi even prior to the Jubilee Year.

Another seventeenth-century account, The Life of Pietro Stefaneschi written by Sebastiano Vannini in 1642, states: "Havendosi in tal guise il futuro anno santo per occasione di muovere il Cardinale a far dipingere in San Pietro, la verità del suo albergare in Roma, il tempo é distintamente l'opere fattevi da Giotto." (Having in such a way the future holy year for the occasion to motivate the Cardinal [Jacopo Stefaneschi] to make the painting in San Pietro, the truth of his stay in Rome, the time is distinctly the works made by Giotto. $)^{90}$ This quotation provides a pre-1300 date for Giotto's Navicella, in anticipation of the Jubilee Year. However, modern scholars believe that Pope Boniface VIII's declaration of the Jubilee Year in February of 1300 was unpremeditated, and had been inspired by the crowds of pilgrims that had already begun flocking to Rome, reportedly the number having been already greatly increased from the usual crowds due to the passage of the century. ${ }^{91}$ So neither Torrigio's nor Vannini's account that associates Cardinal Stefaneschi's commission of Giotto's mosaic with the Jubilee

\footnotetext{
${ }^{89}$ Torrigio, Le Sacre Grotte Vaticane, 90.

${ }^{90}$ De Benedictis, "'La Vita di Pietro Stefaneschi' di Sebstiano Vannini," 982.

${ }^{91}$ Cardinal Stefaneschi's account of the events leading up to BonifaceVIII's promulgation of the Bull declaring the first official Jubilee Year for the church on February 22, 1300, claims that it was an existing popular belief among the faithful that pilgrims would obtain special indulgences for visiting the tomb of the Prince of the Apostles during the year marking the passage of the century, and Boniface VIII, "unwilling that his flock should be deprived of what they had put themselves to great inconvenience to obtain," opened the tradition officially. Herbert Thurston, The Holy Year of Jubilee: An account of the history and ceremonial of the Roman Jubilee (London: Sands Co., 1934), 13.
} 
Year provide firm support for that date. Both authors consistently and convincingly maintain the association of the gatehouse mosaic with pilgrims to Saint Peter's, but this does not contradict a date of 1298 for the commission.

Cardinal Stefaneschi had been composing his Opus metricum, in praise of Pope St. Celestine V throughout the 1290s, so accepting a date of 1298 for the Navicella does not rule out consideration of the papacy and the 1294 abdication of Pope St. Celestine V as a factor in its commission and interpretation. What further evidence there is to support or contradict such an association will therefore be analyzed in the following chapter.

Cardinal Stefaneschi left Rome for France with the curia for the coronation of Pope Clement V in Lyon, and "there is no evidence to suggest that [Cardinal Stefaneschi] ever returned to Italy after $1306 .{ }^{.92}$ This makes it extremely unlikely—rather a point that would have to overcome the weight of evidence of his absence from Rome - that Cardinal Stefaneschi commissioned the Navicella in absentia post-1306, which even then would have been prior to the decisive move of the curia to Avignon. The idea that the Avignon papacy should be considered a factor in the commission or interpretation of the Navicella is not supported by any documentary evidence.

A bit of evidence from January of 1302 can be utilized as a very tentative terminus ante quem for Giotto's Navicella. Pope Boniface VIII in this month commissioned leatherworkers to make a housing of leather for a little golden ship (domo de corio pro navicula aurea) ${ }^{93}$ This unusual commission paid for from the treasury of the church is difficult to understand unless the "navicula" to be so adorned was intended

\footnotetext{
${ }^{92}$ Gardner, "The Stefaneschi Altarpiecce", 71.

${ }^{93}$ Friedrich Baethgen, "Quellen und Untersuchungen zur Geschichte der Papstlichen Hof- und Finanzverwaltung unter Bonifaz VIII" in Quellen und Forschungen aus italienischen Archiven und Bibliotheken, vol. 20 (1928/29): 228.
} 
to be viewed as a symbol of the church. The commission makes even more sense if we accept that the gatehouse mosaic had been recently reconstructed, featuring the "navicula" symbol so prominently, but not so much sense if there was no such historical context for Boniface VIII's commission—or is it simply coincidental that "navicula" and "navicella" are exactly equivalent terms? $?^{94}$ Also noteworthy in this context is KohrenJansen's statement: “Interessant im Hinblick auf die Navicella ist, dass sich der Bedeutungswandel bzw. die Bedeutungserweiterung der Perikope mit wenigen Ausnahmen erst kurz vor 1300 vollzog." (Intereseting in regards to the Navicella is, that the changing meaning or growing meaning of the pericope, with few exceptions, first occurred a little before 1300. $)^{95}$

Primary evidence places Giotto in Rome definitely prior to 1313. In 1923 Luigi Chiapelli first published a document from 1313 he had discovered in the Archivio di Stato in Florence. 96 This legal notice names one Benedetto fu Pace as Giotto's "legitimum procuratorem" to travel to Rome and retrieve his household goods (a substantial amount) from his landlady Filippa da Rieti. ${ }^{97}$ There is no further documentary evidence which places Giotto in Rome after this, so the record provides a reasonable terminus ante quem for Giotto's Roman oeuvre, and definitely provides support for any of Giotto's Roman works to be dated prior to this written record. The very subject of the document, that Giotto is recalling his possessions from Rome back to Florence, supports

\footnotetext{
${ }^{94}$ Navicula is the term used to describe the boat of the apostles in the account of St. Peter walking on the water in the Vulgate, Secundum Mattheum 14.

${ }^{95}$ Kohren-Jansen, Giottos Navicella, 77. The exception to which Kohren-Jansen alludes is the mosaic St. Peter cycle of the $7^{\text {th }} \mathrm{c}$. from the transept wall of Old St. Peter's. Thus the origins of the broad, symbolic, allegorical interpretation of St. Peter being rescued from the sea of Galilee can be located in Old St. Peter's prior to Giotto's commission, but the growing popularity of such an understanding of the image can be dated to a little before 1300, again in perfect agreement with a date of 1298 for Giotto's mosaic.

${ }^{96}$ Luigi Chiapelli, "Nuovi Documenti su Giotto" in L'Arte, vol. 26 (1923): 132-136.

${ }^{97}$ Chiapelli, "Nuovi Documenti su Giotto", 132 and 135-6.
} 
the idea that Giotto did not anticipate any more work in Rome. The recent transport of the papal court to Avignon may have inspired Giotto's conviction that no more Roman commissions would be forthcoming. However, it would be mere conjecture in this context to use this primary evidence to establish anything more definite than the historical reality of Giotto's extended residence in Rome before December 8, 1313.

Finally in this regard, Peter Murray's analysis of the early textual tradition for Giotto's artistic activity can be used to sum up this issue as it relates to the date of the Navicella mosaic in St. Peter's. Murray does not use the silence of Riccobaldo Ferrarese's Compilatio cronologica on Giotto's Roman work, as some have, to date this activity to a period after the history was written (1312-1319). ${ }^{98}$ This approach is certainly logical because Riccobaldo's statement giving the location of Giotto's paintings (in Assisi, Rimini, and Padua) should not be assumed to have mentioned every work by Giotto: Florence is not given as a location either.

Murray's sound argument leads him to accept for Giotto's early work, as he puts it, "the traditional chronology Assisi - Rome, [ in Assisi] we find Giotto and his Franciscan advisers inventing a new iconographical form, based on Bonaventura and the acts of Pope Nicholas IV, which is datable about 1291; after this Giotto returns to Rome and renews his studies of Roman mosaics in preparation for the 'Navicella', which cannot have been begun before the Jubilee of 1300 , since we now know how unpremeditated the idea of a Jubilee was." ${ }^{99}$ The assumption that the Navicella must have been commissioned for the Jubilee year underlies Murray's argument, which causes him to date the mosaic post 1300. Barring that assumption, which is without factual basis,

\footnotetext{
${ }^{98}$ Peter Murray, "Notes on some Early Giotto Sources" in Journal of the Warburg and Courtauld Institutes, vol. 16 , nos. $1 / 2,1953$, pp. 59-61.

${ }^{99}$ Murray, "Notes on some Early Giotto Sources," 74.
} 
Murray's analysis of textual sources provides support for the date of 1298 for Cardinal Stefaneschi's commission of the mosaic.

Again addressing its dating by way of comparison with early dependent works of art, for the analysis of the Navicella fresco in the church of St. Peter-the-Younger in Strasbourg (Figure 14), Werner Körte's extreme conclusions regarding the image and its relationship to Giotto's Navicella are useful to bear in mind:

"Im stilistischen Sinne sagt uns daher seine "Kopie" so gut wie nichts über den Bestand des Urbildes; sie ist, obwohl die früheste aller erhaltenen Wiederholungen, doch nicht entfernt so zuverlässig wie die um drei Jahrhunderte jüngere, barocke Wiedergabe in Rom; ja selbst im rein archäologischen Sinne einer Navicella-Rekonstruktion erfahren wir aus dem grossen Wandbild wenig Neues."

(In the stylistic sense, therefore, this "copy" tells us virtually nothing about the existence of the archetype; it is, though the earliest of all preserved reiterations, three centuries younger than, yet not as reliable as the Baroque rendering in Rome; yes, even in the purely archaeological sense of a Navicella reconstruction we learn little new from the large mural [in St Peter-the-Younger]. $)^{100}$

This view, which would practically negate any conclusion that might be reached regarding the appearance Giotto's mosaic by comparing the fresco with either the Musée Condé drawing or the Beatrizet etching, should at least be tested.

Köhren-Jansen gives the following reasons for establishing the date of the fresco's completion to be close to 1320: "Sowohl die Baugeschichte der ehemaligen Stiftskirche als auch die stilkritische Analyse der Malerei weisen das Wandbild in das Ende der ersten Jahrhundertviertels. Historische Kritieren legen einen terminus ante quem von 1323 nahe." (Both the architectural history of the former cathedral church and the stylistic analysis of the painting point the mural into the end of the first quarter of the

\footnotetext{
${ }^{100}$ Werner Körte, "Die früheste Wiederholung nach Giottos Navicella" in Oberrheinische Kunst: Jahrbuch der oberrheinischen Museen, vol. 10 (1942): 104.
} 
century. Historical criteria suggest a terminus ante quem of 1323. $)^{101}$ It is set within a large (circa 36' x 23') slightly pointed arch above the entrance to the church: a location probably meant to be reminiscent of the placement of Giotto's Navicella, seen when looking back towards the entrance to the atrium of Old St. Peter's.

Unlike the previously discussed fresco in San Piero a Grado, this image has an unquestionable relationship to Giotto's Navicella. The reason for this certainty is that the resemblance of poses of the Apostles in the little ship of the Strasbourg fresco is so close to the poses of the apostles in either the Musée Condé drawing or the Beatrizet etching that it cannot be coincidental. Despite this resemblance, it is the numerous iconographic and stylistic discrepancies that cause Körte to classify the fresco as a "copy" and not a copy, and also to undermine its value for reconstructing the appearance of Giotto's Navicella.

However, let us choose not to heed fully Körte's caveat and use the evidence of the fresco as a lens through which to attempt to view Giotto's mosaic. The Beatrizet etching has something more in common with the Strasbourg fresco than does the Musée Condé drawing. The figure group of Christ and St. Peter is of the same size and on the same picture plane as the boat with the Apostles, and there are two wind-demons, one on each side of the sail. Yet the complete flatness of the style of the fresco accounts for the figures all appearing on the same picture plane, and the limitations of the arch-shaped frame do not allow for the figures of Christ and St. Peter to be enlarged. The sole detail, then, that favors a greater likeness of this fresco to the Beatrizet etching is the pair of wind-demons as opposed to the single one in the Musée Condé sheet.

${ }^{101}$ Köhren-Jansen, H., Giottos Navicella, 164. 
Just suppose that the composition of Giotto's Navicella did look more like the Musée Condé drawing rather than the Beatrizet engraving. Isn't it possible that the Strasbourg painter, producing his "copy" of Giotto's mosaic, might have decided to add a wind demon to the right of the sail for the purpose of symmetry? The symmetry of the arch-shaped frame is completely echoed by the symmetrical arrangement of visual elements in the fresco. The mast, plumb vertical, divides the arched composition exactly in half. The ropes which extend from the cross arm to either end of the boat create two equal sides of a triangle which occupies the center of the image and contains the Apostles. The large rudder supplies the counter-weight to the figures of Christ and St. Peter. Even the waves undulate in an absolutely regular pattern so as not to disturb the harmony of the composition's balance. The exact bilateral symmetry of the row of angels depicted at the bottom of the Navicella fresco in Strasbourg further attests to this artist's strong predilection for symmetrical composition.

There are at least three other iconographic elements that the Strasbourg painter unquestionably added to Giotto's composition because they are absent from the Musée Condé drawing and the Beatrizet etching: the flag at the top of the mast, the stars in the sky, and the armed, mythological sea-creatures in the waves. The fact that these elements were interpolated into the fresco "copy" allows for the possibility that other elements were also added according to the artist's fancy, which clearly tended towards symmetry.

With all these considerations, the chance that Giotto's Navicella was more or less faithfully copied in the Musée Condé drawing is not ruled out. Yet it is still the case that the Strasbourg fresco bears a closer likeness to the Beatrizet etching than the Musée 
Condé drawing does. So the matter must be pursued further before reaching a conclusion.

The last early fresco that must be briefly considered before drawing any conclusions regarding the appearance of Giotto's Navicella is in the Spanish Chapel of Santa Maria Novella, Florence (Figure 19). There is documentary evidence thatAndrea di Bonaiuto was commissioned to undertake this work in $1365 .{ }^{102}$ It is in a triangularshaped, quadripartite, ceiling vault.

The arrangement of elements in this fresco bears a close resemblance to the composition of the Musée Condé drawing. While here there are two wind-demons blowing into the sail, they do so only from the left, which billows over the cross-arm of the mast as in the Musée Condé sheet. ${ }^{103}$ The figures of Christ and St. Peter are depicted on a separate picture plane from that of the boat with the Apostles, and closer to the viewer.

For a moment, suppose that the composition of Giotto's Navicella did more closely resemble that of the Beatrizet etching rather than that of the Musée Condé drawing. It is conceivable that Andrea di Bonaiuto altered his composition from that of Giotto in order to fit his triangular frame. At the apex of the frame there is only room for any wind-demons to the left of the sail and perhaps this artist decided that, since in his composition of the scene both wind- demons are blowing directly in the sail from the left, the sail should billow out further to the right. As the boat with the Apostles occupies the entire upper portion of the frame, the figure group of Christ and St. Peter had to be

\footnotetext{
${ }^{102}$ Köhren-Jansen, Giottos Navicella, 174 n. 67.

${ }^{103}$ There is a third wind-personification - a misty, disembodied, bearded head that blows leftward, just to the left of the top of the ship's mast. This type of figure is not represented in either the Musée Condé drawing or the Beatrizet etching — which verifies, as Körte forewarned, the tenuous value of these early adaptations of Giotto's Navicella for the reconstruction of the original mosaic.
} 
shifted down into the lower right angle of the composition, where on the opposite side the fisherman has been likewise fitted.

To summarize, in the Spanish Chapel, as in Strasbourg and Pisa, the evidence for reconstructing the original appearance of Giotto's Navicella is inconclusive. We are in a position to conclude here that the year 1298 for Giotto's Navicella is sufficiently supported to be accepted unless further evidence comes to light that proves otherwise. Based upon the foregoing analysis of the evidence for dating and reconstruction, there are two possible scenarios:

1. Giotto's Navicella was made in 1298 and continued to exist on the façade of the gatehouse of Old St. Peter's unaltered in its essential composition as shown in the Beatrizet etching until it was removed during the destruction of the atrium in 1610.

2. Giotto's Navicella was made in 1298, appearing as shown in the Musée Condé drawing, and underwent at least one significant alteration from its original composition so that it eventually came to look as shown in the Beatrizet etching. Documentary evidence exists for repairs having first been made on the Navicella in $1514 .{ }^{104}$ More extensive work was done to the mosaic in $1530-33 .{ }^{105}$ One or both of these documented campaigns could have changed the composition of the Navicella mosaic prior to the appearance of the Beatrizet etching in 1559 .

\footnotetext{
${ }^{104}$ Eugenio Müntz, "Les Architectes de Saint-Pierre de Rome: d'apres des documents nouveaux (14471549)" in Gazette des beaux-arts, vol. 20 (1879): 508, n.2.

${ }^{105}$ Ennio Francia, 1506-1606: Storia della costruzione del Nuovo San Pietro (Roma: De Luca, 1977), 43 and 46.
} 
Between these two possibilities, the latter is more likely to be true. Because the Beatrizet etching certainly shows the gatehouse mosaic's composition as it appeared in the second-half of the sixteenth century, the evidence of the inscription on the Musée Condé drawing lends great support to the idea that changes were made over time to Giotto's original composition. But it would be pretentious to dismiss the tradition existing in the sixteenth and seventeenth centuries that the gatehouse mosaic was Giotto's commission from Cardinal Stefaneschi. The way to reconcile this conflicting evidence is to accept that the original composition of Giotto's Navicella did look as it was drawn on the Musée Condé sheet, but that later, through the alteration of the composition to include the four prophets in the clouds, a second wind-demon, and the donor figure in the foreground, it came to appear as recorded in the Beatrizet print. Yet, even with these later iconographical changes it continued to be known as Giotto's Navicella because in all the primary elements (the central little boat with the apostles in the storm, the fictive architecture and fisherman to the left, and the figure group of Christ and St. Peter on the far right) it remained essentially the master's work. ${ }^{106}$

Such an elision is comparable to the way that the Last Judgment fresco in the Sistine Chapel is still referred to as Michelangelo's Last Judgment, despite the fact that Daniele Volterra made changes and additions to the painting that have been retained. Another comparable example from the same context (St. Peter's in the late Renaissance) is present in Matthaus Greuter's engraving (Figure 20) published in Giacamo Grimaldi's Descrizione della basilica antica di S. Pietro in Vaticano. ${ }^{107}$ The image shows a frontal

\footnotetext{
${ }^{106}$ These primary elements are both the iconographic and compositional core of the image. The addition of figures in the clouds, a wind-demon, and a donor figure does very little to alter the signification of Giotto's conception, which will be the main topic of Chapter 5.

${ }^{107}$ Grimaldi, Descrizione, 503-4.
} 
elevation of New St. Peter's after the completion of the dome and Carlo Maderno's façade in 1612. The inscription at the top of the image attributes to Michelangelo all of the architectural design except for the "sacrestia coro per il clero portico loggia per la benedittione campanili e facciata diseganata e fatta da Carlo Maderni" (sacristy, choir for the clergy, benediction loggia, belltowers, and façade designed and made by Carlo Maderno). This ignores the contributions of the litany of architects who were placed in charge of designing the fabric of the basilica both before and after Michelangelo. ${ }^{108}$ That both of these examples of simplified attribution, deferring to the most famous master associated with the work, are derived from the ambit of the Counter-Reformation papacy makes them even more pertinent to the situation in regard to Giotto's mosaic.

The key to proving the validity of the hypothesis that the composition of Giotto's Navicella underwent change, from its original appearance into the composition as seen in the copies of the sixteenth century, is pinpointing when that change occurred and showing what the change was. Heretofore, the diary entry of Antonio di Pietro Schiavo for the first of December in 1404 has not been set forth as the lynchpin for the argument that it is, because there was a lack of certainty about the location of the mosaic which it describes as having been damaged. The diary entry reads: "Item die lune primo mensis decembris de nocte, fuit maxima tempestas venti et aque, et cecidit in ista nocte de labore musaicho ante frontem spicium basilice Sancti Petri, etcetera, videlicet in Paradiso supra ubi venduntur sudarii, etcetera." (The day of Monday, the first of December, at night was a great tempest of wind and water, and in this night some work of mosaic fell from the

\footnotetext{
${ }^{108}$ Those architects working before Michelangelo who are obfuscated by this inscription are: Donato Bramante, Raphael, Fra Giovanni Giocondo, Giuliano da Sangallo, Antonio da Sangallo the Elder, Baldassare Peruzzi, Andrea Sansovino and Antonio da Sangallo the Younger. Those working after Michelangelo are: Pirro Ligorio, Giacomo da Vignola, and Giacomo della Porta.
} 
façade facing the basilica of St. Peter's, etcetera, namely in the Paradiso above where the sudarii are sold, etcetera. $)^{109}$ It has been previously theorized that the mosaic damaged by this storm was Giotto's Navicella, but the possibility that the record instead concerned damage to Pope Greory IX's mosaic on the façade of the basilica had not yet been ruled out. ${ }^{110}$

Another entry in the same diary for October of 1407 contributes further evidence for ascertaining the location of the mosaic: "the first gate of entrance on top of the stairs, namely where the pater nostralia are sold, that is, near C. Caroti's table, etcetera." ${ }^{\prime 11}$ These two terms, sudarii and pater nostralia refer to the same type of pious image sold to pilgrims at St. Peter's. The sudarii (cloths) and the pater nostralia (our Father) were sold as relics at St. Peter's because in the far eastern part of the south-most nave of the basilica was an altar that kept the holy relic of the Veronica, the Sudarius, as shown in Alfarano's plan (Figure 21). This relic was a miraculous image — an acheiropoieta —of the features of Christ made on a cloth which He pressed to his face. Hence, vendors in the atrium sold painted copies of this famous relic to pilgrims, referred to as either cloths, because of the material on which the holy image was impressed, or our Fathers because it was an image of the face of Christ. This is corroborated by the evidence that the vendors in the atrium who sold "sudarii o veroniche" were referred to as "mercerii o paternostrarii."112

\footnotetext{
${ }^{109}$ Ludovico Antonio Muratori ed., Il Diario Romano di Antonio di Pietro dello Schiavo, Raccolta degli Storici Italiani dal cinquecento al millecinquecento, tome 24, part 5 (Città di Castello: coi Tipi della Casa Editrice S. Lapi, 1917) 6. Adding to the evidence for this damage having occurred to the gatehouse mosaic in the atrium, the work done to the gatehouse in 1285 referred to the building as "frontispicium sancte Marie in turribus" (above p. 42, 43 n. 62), very close to the Latin used in the diary entry to refer to the location of the damaged mosaic: "frontem spicium"

${ }^{110}$ See Köhren-Jansen, Giottos Navicella, chapter Geschichte des Mosaiks bis zum Seicento.

${ }^{111}$ Muratori ed., Il Diario Romano, 22. "intrantem primam portam in capite scalarum, videlicet ubi venduntur pater nostralia, videlicet prope banchum C. Caroti, etcetera".

${ }^{112}$ Michele Cerrati, Tiberii Alpharani de basilicae Vaticanae antiquissima et nova structura (Roma:

Tipografia Poliglotta Vaticana, 1914), 15 n.1. "e poi quando numerosi I Pellegrini venivano divotamente a
} 
Here, besides the testimony of the diary as to the location of the damaged mosaic, we can also apply the evidence of the Censuali of 1384, which mentions the sale of holy memorabilia beneath the image of the Savior at the foot of the stairs. These stairs were not the larger series of steps leading up to the atrium from the piazza of St. Peter's, but the small series of steps descending from the level of the gatehouse to the lower pavement level of the courtyard. As visual confirmation of the practice, a vendor at his bench, like the one mentioned in the Censuali and diary entries above, stands between the bronze pinecone in the atrium's center and beneath the Navicella mosaic in Figure 3.

Collating the data from the two diary entries, we can say precisely that the mosaic was "in the Paradiso", or atrium, and that it was over "the first gate of entrance on top of the stairs" and the Censuali of 1384 corroborates the presence of vendors beneath the image. Thus the storm damage in 1404 certainly occurred to the Navicella, but it remains to be shown what changes this produced in the composition of the mosaic when it was repaired. To establish this we must return to the adaptations of the Navicella which were produced prior to the event and compare those with adaptations which were created following the event.

The earliest adaptation of the Navicella mosaic that we have following the tempest of 1404 was made in the second half of the 1400s by Niccolò Alunno in the chapel of the crucifix in Santa Maria in Campis in Foligno (Figure 22). For the first time in a Navicella adaptation now appears the facing pair of half-length figures in the clouds. These did not appear in any of the adaptations prior to the damage incurred by the storm.

prosternarsi presso la tomba gloriosa dell'Apostolo ed insieme col ricordo spirituale di tanta grazia desideravano portare con sè qualche materiale ricordo della grande Basilica, si stabilirono i rivenditori di imagini sacre, di sudarii o veroniche. Se ne ha già notizia nel Liber Ann. (27 luglio) e più ancora nei censuali dei primi anni del secolo XV ove si trova un discrete numero di tali mercerii o paternostrarii come furono detti più tardi". 
Also, a change can be seen in the appearance of the wind-demons. In the adaptations produced prior to 1404 the wind-demons are all posed with their arms below their shoulders and in front of their chests. In the Foligno fresco, again for the first time, we see the wind-demons with one hand supporting the horn and the other arm raised up and touching the back of its head, as they appear in all later copies and adaptations.

This should all be taken as conclusive evidence that a compositional and iconographic shift in the gatehouse mosaic towards resembling the Navicella as it was copied in the Beatrizet engraving took place following the storm damage of 1404. It should not be improbably presumed that the figures in the clouds had been omitted for some reason from all of the previous adaptations of Giotto's Navicella, but after 1404 the adaptations began to include them; nor can it be taken as mere coincidence that prior to 1404 all Navicella adaptations show the wind demons in the one position while after 1404 all Navicella adaptations and copies show the wind demons in a different position, when there is a historical record of the mosaic being damaged in that year.

Now there is even more convincing evidence, adding to that of the inscription and the preceding analysis, to support the hypothesis that the Musée Condé drawing illustrates Giotto's own original composition for the Navicella. The only objection to be overcome before the hypothesis should be accepted as likely is that the kneeling donor figure does not appear in the Musée Condé drawing, while the kneeling donor does appear in the Beatrizet engraving. If the donor figure did not appear in Giotto's mosaic of 1298 , when and why was this figure added?

Certainly the above-noted work done on the Navicella mosaic in 1514 and 15301533 may have further altered the iconography of the composition prior to the record of 
the mosaic produced by Beatrizet in 1559 , featuring the first appearance of the kneeling cardinal in any copy or adaptation of the work. The extent of the work carried out on Giotto's Navicella over the centuries may be hinted at by the wording of the legend provided for Tiberio Alfarano's plan, engraved by Natale Bonifacio from 1589-1590 (Figure 22). The Navicella mosaic is labelled no. 118 on the plan, and the identification on the legend reads: "Tres Portae Sup[ra] quas est restitutta de novo Navicula [...] opera Iotti [spelling?] impensis Iacobi Caietani Cardinalis de Stephanescis." (Three doors above which is re-made anew the Navicella, Giotto's work commissioned by Cardinal Jacopo Gaetani Stefaneschi.) The specific meaning of the term "restitutta" that Alfarano applies to the Navicella of his day can be gleaned from a medal struck by Filippo Bonanni during the pontificate of Pope Paul V (Figure 23). The inscription on the medal states: "Palatii Vaticani Porta Restituta." The raison d'etre for the depiction is the newly built tower designed by Martino Ferrabosco. That this tower was an entirely new construction shows that the term "restituta" meant a drastic re-making of a feature which served the same function as the preceding work.

Another statement from Alfarano yields further evidence: "Iacobus Cardinalis de novo fecit fieri ex opera Iotti naviculam Beati Petri fluctuantem in medijs fluctibus" (Cardinal Stefaeschi caused to be newly made the work of Giotto the Navicella of St. Peter wavering in the midst of the waves). The latter statement refers to Giotto's work in 1298, when the Navicella was newly made (de novo fecit). ${ }^{113}$ Alfarano's former statement refers to the Navicella as having been newly restored (restitutta de novo), yet still maintains the authorship of Giotto for the re-made mosaic and even still refers to

\footnotetext{
${ }^{113}$ Paeseler argues that this statement is proof of the pre-Giotto Navicella being renewed by Giotto, but it is made by quite a late witness, and, like Serrano's hypothesis about Leo the Great having commissioned a Navicella mosaic, is conjectural. See Paeseler, Giottos Navicella und ihr spätantikes Vorbild, 160.
} 
Cardinal Stefaneschi as the patron. Here we have a possible explanation for the insertion of the donor figure into the restored work: the motivation to preserve and display historical continuity with the commission of 1298 . When extensive restorations of the mosaic were undertaken in 1530-1533, much of Old St. Peter's had been demolished and the fate of what remained must have been regarded as uncertain. At this time, the insertion of the kneeling figure of the cardinal into the composition reasserted the connection of the Navicella with its illustrious roots, exactly as Alfarano does in the legend for Bonifacio's papally licensed engraving by attributing the newly restored work (post-1533) to Giotto as commissioned by Cardinal Stefaneschi. 


\section{CHAPTER V}

\section{THE SIGNIFICATION OF THE NAVICELLA MOSAIC IN THE LATE RENAISSANCE ATRIUM OF OLD ST. PETER'S}

Conspicuously, Old St. Peter's was constructed with an apse (and the sanctuary where the priest performs the holy rite of Mass) at its western extreme. This is opposite of most European Christian churches, where the apse is situated at the eastern end of the building. As we have seen, to such a reversal of orientation can be attributed much of the importance of the gatehouse mosaic throughout its history, because Christian worshipers from early times held the tradition of praying towards the rising sun in the east—and this usually meant praying towards the sanctuary of the church, which seemed perfectly appropriate.

There must have been a strong reason for Old St. Peter's basilica to have been constructed in such a special way, on an exact east-west axis, but no compelling theory has been put forth. Turpin C. Bannister's erudite, and rather grueling, study of the proportions and layout of Old St. Peter's theorized that the unknown Roman architect who designed it, did so with the intention of creating a building with a great amount of theological significance embedded in its disposition of architectural features and proportions. ${ }^{114}$ Using the same standard module of measurement observed by Ezekiel in his vision of the temple — the Ptolemaic foot (Ezekiel 40-43) — and an arrangement of elements quite comparable to Solomon's Temple as well, the intention of the architect to

\footnotetext{
${ }^{114}$ Turpin C. Bannister, "The Constantinian Basilica of Saint Peter at Rome" in Journal of the Society of Architectural Historians, vol. 27, no. 1 (Mar., 1968): 3-32.
} 
create a Christian most holy building on these models seems quite possible. ${ }^{115}$ In Solomon's temple as in Old St. Peter's “the general sequence of elements - steps, gatehouse, court, porch, nave, and sanctuary —is at once apparent." ${ }^{\prime 16}$ Bannister also notes "the legend that some of its [Old St. Peter's] building materials, particularly the spiral columns in the apse, had been brought from the ruins of Solomon's Temple." "117

What Bannister does not state, however, is perhaps the most striking conclusion to be drawn from his theory, that the "occidentation" of Old St. Peter's is due to its being modelled upon the temple in Jerusalem, where the Holy of Holies was situated at the western end and the gate to the courtyard at the eastern end. From Ezekiel 43:1-5 (NRSV):

Then he brought me to the gate, the gate facing east. And there, the glory of the God of Israel was coming from the east; the sound was like the sound of mighty waters; and the earth shone with his glory. The vision I saw was like the vision that I had seen when he came to destroy the city, and like the vision that I had seen by the river Chebar; and I fell upon my face. As the glory of the Lord entered the temple by the gate facing east, the spirit lifted me up, and brought me into the inner court; and the glory of the Lord filled the temple.

In this excerpt from Ezekiel's vision of the future temple, the temple whose standard unit of measurement the architect of Old St. Peter's seems to have adopted, there are certain parallels with features of the Vatican basilica. The major entrance to the temple was through the gate facing east. Beyond this, could the sound of mighty waters coming from the east have been part of the inspiration for the maritime subject matter of the gatehouse mosaic? Is the reference to destroying the city a foreshadowing of the

\footnotetext{
${ }^{115}$ Bannister, "The Constantinian Basilica of Saint Peter", 13 and 16-17.

${ }^{116}$ Bannister, "The Constantinian Basilica of Saint Peter", 17. Also, in specific reference to the atrium of Old St. Peter's, Bannister notes: Two other examples of Temple influence deserve mention. First is the close correspondence of the Vatican entrance system with its stair, terrace, gatehouse, atrium, fountain kiosk, and narthex to the Temple sequence of steps, gate, courtyard, laver and porch." 20.

${ }^{117}$ Bannister, "The Constantinian Basilica of Saint Peter", 25.
} 
overthrow of paganism, as Constantine's grand Christian building projects announced? Ezekiel fell on his face as he saw the Lord coming from the east, as was the practice before the gatehouse mosaic. Could it be symbolic of the Lord entering the temple by the gate facing east that the gatehouse contained the sacred shrine dedicated to the Virgin Mary, Mother of God, through whom the Lord entered the world? Could it be that the architect saw himself as fulfilling Ezekiel's vision of a new temple and Christ's prophecy to St. Peter that He would build His church upon him?

Such speculation aside, it seems the best solution to the mystery of Old St. Peter's westward-facing sanctuary and eastward-facing gate rest with the theory that the architect intended to create a building overtop the Shrine of St. Peter that compares with the Biblical precedents of Solomon's Temple and the temple of Ezekiel's vision. In any case, even if there was no intended significance to the basilica's reversed orientation, that the gatehouse was on the eastern end of the basilica's plan and that praying towards the east meant praying towards the gatehouse mosaic is a factor to consider in understanding the signification of the Navicella.

The best approximation of the appearance of the Navicella in the Late Renaissance atrium of Old St. Peter's is Orazio Manenti's 1674 mosaic of the same subject (Figure 24). This mosaic was constructed on the model of the gatehouse mosaic, after it had suffered many ruinous events during the destruction of the atrium, and it is to be preferred as an approximation of the visual effect of the gatehouse Navicella mosaic to both the Beatrizet etching (Figure 4) and the Berretta painting (Figure 17) due to their being in entirely different media. ${ }^{118}$ However, in analyzing the signification of the

\footnotetext{
${ }^{118}$ A major deficiency in the visual effect of Manenti's mosaic in gauging the effect of the gatehouse mosaic is the fact that the extant work is in a rather poorly lit interior position, which contrasts with what
} 
gatehouse mosaic, it is absolutely essential to bear the Beatrizet etching in mind because it records the Navicella composition in situ during the period under consideration.

But to this visual aid must be added the configuration of the other important ornaments of Old St. Peter's atrium. The largest of these features was directly opposite the Navicella, the basilica's façade mosaic of the Revelation of Christ at his second coming, with Christ in a mandorla, the four, quadruple-winged heavenly creatures representing the four gospels of the New Testament, and the twenty-four elders in adoration. This appears in Grimaldi's early sixteenth-century drawn perspective of the forecourt along with the famous centerpiece of the pinea aenea (bronze pinecone) and the rectangles above the arcaded portico attached to the basilica's façade, the location of the aforementioned scenes of the life of St. Peter found in the Golden Legend (Figure 25).

The scenes from the later life of St. Peter are historical in nature and are depicted to inform worshipers about St. Peter's ministry in Rome as well as the reality of the basilica having been founded upon the spot where his relics were deposited following his martyrdom by upside-down crucifixion in the Circus of Nero by making scenes from this course of events visible for the worshiper. The pinea aenea was, as a seed, a symbol of renewal and, as a fountain, a symbol of welcome. The façade mosaic symbolized the transition from the earthly paradise, the forecourt, to the heavenly paradise, the interior of the basilica. ${ }^{119}$

must have been the Navicella's reflective tesserae's splendorous interaction with the open air, sunlight, and surroundings.

${ }^{119}$ Filippo Maria Mignanti, 'Istoria della sacrosanta patriarcale basilica Vaticana: Dalla sua fondazione fino al presente, vol. 1 (Roma: Ufficio della Civiltà Cattolica, 1867) 29. "Essa in origine fa piantata di alberi simbolici, come palme, olivi, cipressi, rose, cedri, viti, a figurare l'Eden ossia il paradiso terrestre, come la basilica che susseguiva era simbolo del celeste; ed è per questo che all'area medesima veniva dato il nome di paradiso, che ritenne anche quando recisi gli alberi fu lastricata, prima con mosaici e poi con marmi da Papa Dono." 
While bearing in mind the architectural and ornamental context when considering the signification of the Navicella, we have as a primary consideration the Gospel passage of the event itself, which supplies much—but not all—of the subject matter depicted in the mosaic. While scholars as a whole have viewed the Navicella as a representation of events found in Matthew 14:22-31 or 33, yet owing to the inscription's prominent mention of reaching the port, the Navicella should be regarded as referring more inclusively to Matthew 14: 22-36 (NRSV):

Immediately he made the disciples get into the boat and go on ahead to the other side, while he dismissed the crowds. And after he had dismissed the crowds, he went up the mountain by himself to pray. When evening came, he was there alone, but by this time the boat, battered by the waves, was far from the land, for the wind was against them. And early in the morning he came walking toward them on the sea. But when the disciples saw him walking on the sea, they were terrified, saying, "It is a ghost!" And they cried out in fear. But immediately Jesus spoke to them and said, "Take heart, it is I; do not be afraid." Peter answered him, "Lord, if it is you, command me to come to you on the water." He said, "Come." So Peter got out of the boat, started walking on the water, and came toward Jesus. But when he noticed the strong wind, he became frightened, and beginning to sink, he cried out, "Lord, save me!" Jesus immediately reached out his hand and caught him, saying to him, "You of little faith, why did you doubt?" When they got into the boat, the wind ceased. And those in the boat worshiped him, saying, "Truly you are the Son of God."

When they had crossed over, they came to land at Gennesaret. After the people of that place recognized him, they sent word throughout the region and brought all who were sick to him, and begged him that they might touch even the fringe of his cloak; and all who touched it were healed.

But this is not the only Biblical passage that bears upon the signification of the Navicella. We can see to the left of the boat in Mario Labacco's 1567 engraving of the Navicella (Figure 26), which followed Beatrizet's etching, that at least one other Biblical passage had been viewed as an aid to understanding the mosaic. Inscribed there is from Secundum Lucam 22, 32: "Ego autem rogavi pro te ut non deficiat fides tua." (I have prayed for you that your faith will not fail.) This passage is in reference to St. Peter's 
three-fold denial of Christ during His Passion, but the excerpt in the context of the Navicella is an assurance that, because of Christ's intervention, St. Peter's faith (the Catholic faith symbolized by the boat with the apostles) shall not falter.

Labacco's engraving also assures us that for a late-sixteenth-century viewer, the Navicella mosaic did more than simply illustrate the Gospel scene. Above the pair of figures in the clouds to the left is the phrase: "Fluctuat assidue quamvis Ecclesia, numquam mergitur; huic semper dat quia Christus opem." (However incessant the waves, the Church is never submerged; for always Christ gives help.) This alludes again to Christ's unfailing care for the Church and also confirms the definite idea that the boat in this particular image symbolizes the Church.

The Navicella takes Pope St. Gregory the Great's declaration to the iconoclast Bishop of Marseilles, that those who do not know letters can read the Bible through the images in a church, one step further than it is usually taken; it is an exegesis of Matthew 14:22-36, like a homily for the illiterate. ${ }^{120}$ Christ leaves the apostles to pray on the mount; this is His ascension to Heaven. The apostles are left in the boat on the waves; this is the Church persecuted. Jesus returns in the fourth watch of the night; this is the end of the age, His second coming. ${ }^{121}$ St. Peter is the first to be united with Christ, followed by the rest of the Church; this is St. Peter's foundational importance to

\footnotetext{
${ }^{120}$ Jacques-Paul Migne, Patrologia Cursus Completus, vol. 77, 1027-1028. ““'Idcirco enim picture in Ecclesiis adhibetur, ut hi qui litteras nesciunt, saltem in parietibus videndo legant quae legere in Codicibus non valent."

${ }^{121}$ St. Jerome, Commentariorum in evangelium Mathaei, in J. P. Migne ed. Patrologia Cursus Completus, vol 7., 102. "Stationes et vigliae militares in terna horarum spatial dividuntur. Quando ergo dicit, quarta vigilia noctis venisse ad eos Dominum, ostendit tota nocte periclitatos, et extrema parte noctis, atque in consummation mundi eis auxilium praebiturum."
} 
salvation. ${ }^{122}$ The Navicella disembarks in Genesaret, where all who come to Christ are healed; this is eternity in Heaven. ${ }^{123}$

The ecclesiastical historian Cardinal Cesare Baronio (1538-1607) is reported to have knelt in front of the Navicella and recited this brief prayer: "Domine ut erexisti PETRUM à fluctibus, ita eripe me à peccatorum undis." (Lord as you raised St. Peter from the waters, so raise me from the waves of $\sin .)^{124}$ Now, to the boat as a symbol for the Church in the mosaic, we can add the waves as a symbol for sin.

The inscription below the Navicella, reproduced and translated in full in chapter one, must also be thought of as a prayer to be recited by worshipers at Old St. Peter's. In addition to being worded as a prayer to God, it seems to have been flanked by two roundels containing busts of angels - the archetypal intermediaries between God and humans. This original placement of the two surviving mosaic angel busts now in the Sacre Grotte of St. Peter's (Figure 27) and Boville Ernica (Figure 28) was argued convincingly by Werner Körte on account of the fragmentary borders still visible outside the edges of the roundels. ${ }^{125}$ These angels, Baronio's prayer, the evidence for worshipers

\footnotetext{
${ }^{122}$ St. John Chrysostum as quoted in P. Angelici Guarienti ed., S. Thomae Aquinatis, Doctoris Angelici: Catena Aurea in Quator Evangelia, vol. 1 (Turin: Marietti, 1953) 232. "Petrus autem quod maius est superans, scilicet undam maris, a minori turbatur, scilicet a venti impulse: unde sequitur 'Videns autem ventum validum timuit'. Talis est enim natura humana ut multoties in magnis recte se habens, in minoribus reprehendatur. Hic autem quod Petrus timuit, differentiam monstrabat magistri et discipuli; sed et alios discipulos mitigabat. Si enim in duobus fratribus sessuris ad dexteram moestati sunt, multo magis hic molestati fuissent: nondum enim errant spiritu pleni; postea vero spirituals efffecti, ubique Petro primatum concedunt, et in concionibus eum praemittunt."

${ }^{123}$ St. Jerome, Commentariorum in evangelium Mathaei, in J. P. Migne ed. Patrologia Cursus Completus, vol 7., 104. "Si sciremus quid in nostra lingua resonaret Genesareth, intelligeremus quomodo Jesus per typum apostolorum et navis, Ecclesiam de persecutionis naufragio liberatam transducat ad littus, et in tranquillissimo portu faciat requiescere."

${ }^{124}$ Carlo Bartolomeo Piazza, Efemeride Vaticana per i ecclesiastici d'ogni giorno dell'augustissima basilica di S. Pietro in Vaticano (Roma: Per gl'Eredi del Corbelletti, 1687) 388.

${ }^{125}$ Werner Körte, "Die 'Navicella' des Giotto," in Festschrift Wilhelm Pinder zum sechzigsten Geburtstage (Leipzig: Seemann, 1938), 223-263, and especially 249-256.
} 
praying towards the gatehouse, and the inscription below the mosaic leave no room for doubt that part of the signification of the Navicella was salvific efficacy for the faithful.

The most expansive early-modern interpretation of Giotto's Navicella was written by Filippo Baldinucci in his Notizie, part of which was discussed in detail above. Further on in his biography of Giotto, Baldinucci returns to the subject of the Navicella, and after recounting the narrative content of the image by summarizing Matthew 14 up to the point when Christ asks of St. Peter: "You of little faith, why did you doubt?" he elaborates on what he terms the mystery of the mosaic. "Appresso a questa finse alcuni demoni in similitudine di venti, che con soffi gagliardi pare che procurino di somergere essa Nave, figurata per la Santa Chiesa, da Christo condotta al porto di salute. Veggonsi dall'una all'altra parte di essa fra le nubi i quattro vangelisti, ed ella illustrata da alti splendori mostra, che nel continuo urtar dell'onde, se bene alcuna volta sembra di titubare e vacillare, non mai però si sommerge." (Near to this appear some demons in the likeness of winds, that with great puffs appear to attempt to submerge the boat, figure for the Holy Church, conducted by Christ to the port of salvation. Going from one to another part of it, among the clouds are the four evangelists, and they show from ahigh the splendors, that in the continual knocking of the waves, it truly sometimes seems to totter and waver, but never does submerge.) ${ }^{126}$

Baldinucci interprets the wind-demons as symbols of demonic forces trying to submerge the Boat of the Holy Church, adding the detail, in accordance with the inscription and the final three verses of Matthew 14, that Christ conducts the Boat to the port of salvation. Baldinucci calls the four figures in the clouds the four evangelists, but this last major item of the interpretation is open to doubt on two counts. First, the event

${ }^{126}$ Baldinucci, Notizie, 111. 
of St. Peter walking on the water is only recounted by one evangelist, St. Matthew. Second, all four of the figures in the clouds are bearded, which would be atypical for the iconography of St. John the Evangelist. Yet, no other convincing identifications have been put forth for these figures. And Giotto did depict St. John the Evangelist as bearded in his Peruzzi Chapel fresco of St. John in exile on Patmos. Therefore, if the four figures are intended to be the authors of the four Gospel books, their presence would add to the evidence for exegetical interpretation of the Navicella by encouraging the viewer to look beyond the narrative of Matthew 14 for the deeper meaning of the mosaic. One further connection could be made with the significance of the architectural context if we are to cocnceive of these figures as the four evangelists; they would be the counterparts to the four quadruple winged angels symbolizing the evangelists in the façade mosaic. This would reinforce the eschatological interpretation of the Navicella by connecting it with the mosaic of Christ's second coming. Still, that the four figures are the four evangelists has not been determined.

For the influence of historical circumstances that sometimes factor into scholarly interpretations of the work, there is no evidence. All the historical events sometimes associated with Stefaneschi's commission were ruled out by the determination of the date as 1298 - except the abdication and process of canonization of Celestine V. Yet this factor can be ruled out of the interpretation as well because no indication of Celestine V's papacy, abdication, or saintliness appears in the mosaic. In notable contrast, in another of Cardinal Stefaneschi's commissions to Giotto, the Stefaneschi altarpiece (the interpretation of which does concern the hermit pope), Celestine $\mathrm{V}$ is depicted. It stands 
to reason then, that Cardinal Stefaneschi, had he wanted to include a specific reference to Celestine V in the Navicella, would have been direct about it.

On the other hand, it is part of the "mystery" of the Navicella that the mosaic was intended to refer to all the trials and triumphs of the Church, those that happened before 1298, and those that happened afterwards. In the early Christian era, Arianism was the demonic forces trying to submerge the Ship and the Council of Nicaea was Christ's safe guidance. Later, the Great Schism was the demons' work and the Council of Constance was Christ's work, and so on throughout the ages of the Church. It is rather a miraculous thing to consider how true that message of the Navicella has been, that the Church will encounter grave difficulties but will persevere.

But there is a more personal message embedded in the Navicella, too. Just as the Church is bound to suffer at the hands of demonic forces and ultimately triumph, so is the Christian individual. St. Thomas Aquinas's Golden Chain (circa 1264) is a commentary and florilegium of quotations from Church Fathers on the four Gospels, requested from him by Pope Urban IV. It supplies an abundance of exegetical material for the signification of Matthew 14:22-36. From among all the truly relevant quotations adduced in St. Thomas Aquinas's commentary (which to comment on them all in connection with the Navicella would be appropriate for a book, but too lengthy here) one from St.

Augustine can demonstrate eloquently the balance of sweeping historical significance and deep personal significance in the Navicella:

"In uno etiam Apostolo, idest Petro, in ordine Apostolorum primo et praecipuo, in quo figurabatur Ecclesia, utrumque genus significandum fuit; idest firmi in hoc quod super aquas ambulavit, et infirmi in hoc quod dubitavit: nam et unicuique sua cupiditas tempestas est. Amas Deum? Ambulas supra mare: sub pedibus tuis est saeculi timor. Amas saeculum? Absorbet te. Sed cum fluctuat cupiditate cor tuum, ut vincas cupiditatem, invoca Christi divinitatem." 
(In one Apostle, St. Peter, in the order of Apostles first and especially, in whom is figured the Church, both types were signified; that is sturdiness in those that walked upon the waters, and instability in those that doubted: for also anyone whose passion is a tempest. You love God? You walk on the sea: under your feet is fear of the ages. You love the world? You are swallowed up. But when passions flood your heart, to conquer passion, invoke Christ's divinity.) ${ }^{127}$

Having addressed the lack of evidence for limiting the signification of the Navicella by attaching its commission to a specific historical circumstance, there remain many other valid scholarly interpretations of the mosaic. The most in-depth treatment of the iconographic elements in the Navicella and their symbolic value can be found in Köhren-Jansen. While the preceding discussion has covered the significance of some elements discussed by Köhren Jansen, such as the ship in the storm and the figures in the clouds, her analysis of the Navicella's reference to the traditio legis type of image is essential to a full understanding of the mosaic's signification. ${ }^{128}$

The traditio legis iconography was quite popular for apse mosaics, for instance in the apse of San Giorgio in Velabro, Rome (Figure 28). Put simply, the image depicts Christ handing a scroll of the Law to St. Peter, symbolizing His charge to St. Peter to safeguard the articles of Christian dogma, which charge is passed on to his papal successors. It is an image connoting the doctrine of papal primacy, the absolute authority over the Church invested in the papal see. That the Navicella mosaic of the sixteenth century, as recorded in the Beatrizet etching, mirrors this type of image can be seen foremost in the fact that Christ is depicted holding a scroll in one hand and reaching St. Peter with the other. Also, the placement of the Navicella at the east end of the basilica parallels the usual eastern-apse placement of a traditio legis scene.

\footnotetext{
${ }^{127}$ P. Angelici Guarienti ed., S. Thomae Aquinatis, Doctoris Angelici: Catena Aurea in Quator Evangelia, vol. 1 (Taurini: marietti, 1953) 235.

${ }^{128}$ Köhren-Jansen, Giottos Navicella, 97-122.
} 
The other scholarly interpretation of the Navicella that must be noted here is from Michael Viktor Schwarz. "Die Inschrift, die materiell den ins Atrium fuhrenden Toren, ideell aber dem Bild zugeordnet war, verknupfte den Weg auf engste mit dem Bild." (The inscription, which materially related to the gates leading into the atrium, but was ideally associated with the picture, closely linked the path with the picture.) ${ }^{129}$ Building upon this observation, the fourth word of the inscription "gradientem" would call to the worshipers mind their recent experience of having ascended the monumental staircase leading to the platform of the atrium. The final word of the inscription "portum" would call to mind the experience of entering and exiting through gatehouse itself with its famous three doors "portae".

The signification of the Navicella mosaic for the worshiper at Old St. Peter's was closely bound to the signification of the site. Christ's consignment of the keys to heaven to St. Peter and his successors' consequent power to bind and loose sin was the primary motivation bringing the masses of pilgrims to the site, to obtain remission from sin and attain salvation. The inscription beneath the mosaic is evidence not only of the rather well-documented practice of praying in front of the mosaic, but more subtly of a tradition that still persists at New St. Peter's.

The last two words of the inscription "contingere portum" certainly attest to the belief in the salvific power of worshiping at Old St. Peter's, but they also recall the practice still observed of touching the Holy Door of the basilica during a Jubilee Year for forgiveness of punishment due to sin: "contingere portam". The Biblical and exegetical tradition of relating male and female forms of words is sufficient to support the possibility of this hypothesis: for instance "virgo" and "virgam", and with especial

${ }^{129}$ Viktor Schwarz, Giottus Pictor, 271 
relevance to this context "petram" and "Petrus". The conclusion of the inscription gave concise assurance to the faithful that their pilgrimage to worship at Old St. Peter's would obtain its object, salvation, and hinted at, the possibly vastly ancient tradition of obtaining absolution by physical contact with the Holy Door of the church.

The phrase "contingere portum" is also connected back with the eschatological interpretation of Matthew 14:22-36. The event of the Navicella (the Church) reaching its "portum" (Genesaret/Heaven) is followed directly by the healing of the faithful through touching ("tangerent" and "tetigerunt") Christ. ${ }^{130}$ It could now be stated that the inscription beneath the mosaic was a prayer for the Church to reach God, exactly as St. Peter did in the mosaic above.

Having explored the signification of the Navicella mosaic in the Late Renaissance atrium of Old St. Peter's, we have found that it was a beacon for the worshipers to pray, an assurance that their prayers would be granted, and it was an awesome illustration of a biblical scene, and a profound commentary on that scene's symbolism. The history of the gatehouse mosaic showed us that Giotto's mosaic was executed under certain preexisting conditions: foremost, the history and religious significance of the Vatican basilica, also, the tradition of worshipers praying towards his Navicella's predecessor on the gatehouse, and its placement amongst the ornaments of the Paradise. Finally, the analysis of the date and appearance of Giotto's Navicella reconciled the conficting evidence of the historical record and showed us why it would be appropriate to continue to call Orazio Manenti's mosaic in the narthex of New St. Peter's "Giotto's Navicella".

\footnotetext{
${ }^{130}$ Secundum Mattheum 14:36.
} 


\section{REFERENCES}

Andaloro, Maria, Silvia Maddalo, and Massimo Miglio, eds. Frammenti di memoria: Giotto, Roma e Bonifacio VIII. Roma: Istituto storico italiano per il medio evo, 2009.

Angelici Guarienti, P., ed. S. Thomae Aquinatis, Doctoris Angelici: Catena Aurea in Quator Evangelia, vol. 1. Turin: Marietti, 1953.

Baethgen, Friedrich. "Quellen und Untersuchungen zur Geschichte der Papstlichen Hofund Finanzverwaltung unter Bonifaz VIII." Quellen und Forschungen aus italienischen Archiven und Bibliotheken, vol. 20 (1928/29): 114-237.

Baldinucci, Filippo. Notizie dei professori del disegno. Vol. 1. Firenze: V. Batelli e Compagni, 1845, vol. 1.

Bannister, Turpin, C. "The Constantinian Basilica of Saint Peter at Rome." Journal of the Society of Architectural Historians, vol. 27, no. 1 (Mar., 1968): 3-32.

Cascioli, Giuseppe. "La Navicella di Giotto a S. Pietro in Vaticano." Bessarion, 32 (1916): 118-138.

Cerrati, Michele. "Il tetto della Basilica Vaticana rifatto per opera di Benedetto XII." Mélanges d'archéologie et d'histoire, 35 (1915): 81-117.

Cerrati, Michele. Tiberii Alpharani de basilicae Vaticanae antiquissima et nova structura. Roma: Tipografia Poliglotta Vaticana, 1914.

Chiapelli, Luigi. "Nuovi documenti su Giotto.” L'Arte, vol. 26 (1923): 132-136.

Ciardi Dupré dal Poggetto, Maria Grazie. Il Maestro del Codice di San Giorgio e il cardinale Jacopo Stefaneschi. Firenze: Editrice Edam, 1981.

D’Achiardi, Pietro. "Gli Affreschi di San Piero a Grado presso Pisa e quelli già esistenti nel Portico della Basilica Vaticana." Atti del Congresso Internazionale di Scienze Storiche, vol. 7, n. 4 (1915): 193-285.

Francesca Flores d'Arcais. Giotto, $2^{\text {nd }}$ edition. New York and London: Abbeville Press Publishers, 2012.

De Benedictis, Cristina. “'La Vita di Pietro Stefaneschi’ di Sebastiano Vannini.” Annali 
della Scuola Normale Superiore di Pisa. Classe di Lettere e Filosofia, Serie III, vol. 6, no. 3 (1976): 955-1016.

De Blaauw, Sible. Studi e Testi no. 356: Cultus et decor, vol. 2. Città del Vaticano: Biblioteca Apostolica Vaticana, 1994.

Degenhart, Bernhard and Annegrit Schmitt. Corpus der Italienischen Zeichnungen: 1300-1450, vol. 1. Berlin: Gebr. Mann Verlag, 1968.

De Rossi, Giovanni Battisti. Inscriptiones Christianae urbis Romae, vol. 2, part 1. Romae: Ex Officina Libraria Pontificia, 1888.

Duchesne, Louis. Le Liber pontificalis, vols.1 and 2. Paris: Éditions E. de Boccard, 1981.

Egidi, Pietro. Necrologi e libri affini della provincia romana vol. 1. Roma: Nella Sede dell'Istituto Palazzo dei Lincei, 1908.

Ephrussi, Charles and Gustave Dreyfus. Catalogue descriptif des dessins de maîtres anciens exposés à l'École des Beaux-Arts mai-juin 1879. Paris: Typ. G. Chamerot, 1879.

Francia, Ennio. 1506-1606: Storia della costruzione del Nuovo San Pietro. Roma: De Luca, 1977.

Freeland, Jane Patricia and Agnes Josephine Conway, (translated). The Fathers of the Church: A New Translation, vol. 93, St. Leo the Great: Sermons. Washington, D.C.: The Catholic University of America Press, 1996.

Gardner, Julian. "The Stefaneschi Altarpiece: A Reconsideration." Journal of the Warburg and Courtald Institutes, 37 (1974): 57-103.

Goñi, José. "Monseñor Hubert Jedin in memoriam." Scripta theologica, vol. 13, no. 1 (1981): 231-238.

Güterbock, Ferdinand, ed. Monumenta Germaniae historica, scriptores rerum germanicarum, nova series vol. 7: Ottonis Morenae et continuatorum historia Frederici I. Berlin: Weidmannsche Buchhandlung, 1930.

Herringham, C. J., trans. The Book of Art of Cennino Cennini. London: G. Allen, 1899.

Hueck, Irene. "Das Datum des Nekrologs für Kardinal Jacopo Stefaneschi im Martyrologium der Vatikanischen Basilika." Mitteilungen des Kunsthistorischen Institutes in Florenz, vol. 21, n. 2 (1977): 219-20. 
Köhren-Jansen, Helmtrud. Giottos Navicella: Bildtradition, Deutung, Rezeptionsgeschichte. Worms am Rhein: Wernersche Verlagsgesellschaft, 1993.

Körte, Werner. "Die früheste Wiederholung nach Giottos Navicella." Oberrheinische Kunst: Jahrbuch der Oberrheinischen Museen, vol. 10 (1942): 97-104.

Körte, Werner. "Die 'Navicella' des Giotto." In Festschrift Wilhelm Pinder zum sechzigsten Geburtstage (Leipzig: Seemann, 1938), 223-263.

Krautheimer, Richard. Corpus basilicarum Christianarum Romae, vol. 5. Città del Vaticano: Pontificio Istituto di Archeologia Christiana, 1980.

Maddalo, Silvia. "Bonifacio VIII e Jacopo Stefaneschi : ipotesi di lettura dell'affresco della loggia lateranense." Studi romani: rivista bimestrale dell'Istituto di Studi Romani, vol. 31 (1983): 129-150.

Mai, Angelo. Scriptorum veterum nova collection, vol. 5. Romae: Typis Vaticanis, 1831.

Mancini, Giulio. Considerazioni sulla pittura, vol. 1. Roma: Accademia Nazionale dei Lincei, 1956.

Mignanti, Filippo Maria. 'Istoria della sacrosanta patriarcale basilica Vaticana: Dalla sua fondazione fino al presente, vol. 1. Roma: Ufficio della Civiltà Cattolica, 1867.

Migne, Jacques-Paul, ed. Patrologia cursus completus, Series Latina. Paris: J.-P. Migne, 1862.

Mitchell, Charles. "The Lateran Fresco of Boniface VIII." Journal of the Warburg and Courtauld Institutes, vol. 14, nos. 1/2 (1951): 1-6.

Muñoz, Antonio. "Le Pitture del portico della vecchia Basilica Vaticana e la loro datazione." Nuovo bollettino di archeologia cristiana, vol. 19 (1913): 175-180.

Müntz, Eugenio. "Les Architectes de Saint-Pierre de Rome: d'apres des documents nouveaux (1447-1549)." Gazette des beaux-arts, vol. 20 (1879): 506-524.

Müntz, Eugène and Arthur L. Frothingham. Il Tesoro della Basilica di S. Pietro in Vaticano. Roma: Società Romana di Storia Patria, 1883.

Muratori, Ludovico Antonio, ed. Il Diario romano di Antonio di Pietro dello Schiavo. In Raccolta degli storici italiani dal cinquecento al millecinquecento, tome 24, part 5. Città di Castello: coi Tipi della Casa Editrice S. Lapi, 1917.

Murray, Peter. "Notes on some Early Giotto Sources." Journal of the Warburg and 
Courtauld Institutes, vol. 16, nos. 1/2 (1953): 58-80.

Niggl, Reto, ed. Giacomo Grimaldi: Descrizione della Basilica antica di s. Pietro in Vaticano. Roma: Biblioteca Apostolica Vaticana, 1972.

Paeseler, Wilhelm. Giottos Navicella und ihr spätantikes Vorbild. Wien: Verlag Anton Schroll \& Co., 1941.

Piazza, Carlo Bartolomeo. Efemeride Vaticana per i ecclesiastici d'ogni giorno dell'augustissima basilica di S. Pietro in Vaticano. Roma: Per gl'Eredi del Corbelletti, 1687.

Prou, Maurice. Compte de la Maison de l'Aumone de Sainte-Pierre de Rome. Paris: Libraire Ancienne Honoré Champion, 1918.

Schmale, Franz-Josef. "Überlieferung und Text des 'Libellus' des Otto Morena und seiner Fortsetzer." Deutsches Archiv für Erforschung des Mittelalters, vol. 41 (1985): 438-459.

Schwarz, Michael Viktor. "Giotto's Navicella zwischen 'Renovatio' und 'Trecento': ein genealogischer Versuch.” Wiener Jahrbuch fur Kunstgeschichte (1995): 129-163 and $277-288$.

Schwarz, Michael Viktor. Giottus Pictor, vol. 2. Wien: Böhlau, 2008.

Serrani, Marcus Attilii. De Septem urbis ecclesiis. Romae: Apud Haeredes Antonij Bladij Impressores Camerales, 1575.

Sodi, Stefano and Mariagiulia Burresi. La Basilica di San Piero a Grado. Pisa: Edizioni ETS, 2010.

Tertullian, De Baptismo: Adversus Quintilliam. In Jacques-Paul Migne ed., Patrologia Cursus Completus, vol. 1. Parisiis: Excudebat Migne, 1844.

Thurston, Herbert. The Holy Year of Jubilee: An account of the history and ceremonial of the Roman Jubilee. London: Sands Co., 1934.

Torrigio, Francesco Maria. Le Sacre Grotte Vaticane. Viterbo: Appresso i Discepoli, 1618.

Torrigio, Francessco Maria. Le Sacre Grotte Vaticane, parts 1 and 2. Roma: Appresso Iacomo Facciotti, 1635.

Van Marle, Raimond. The Development of the Italian Schools of Painting, vol. 3. The Hague: Martinus Nijhoff, 1924. 
Vasari, Giorgio. Le Vite de' più eccelenti pittori, scultori, e architettori, Paola Della Pergola, Luigi Grassi e Giovanni Previtali, eds., vol. 2. Novara: Istituto Geographico de'Agostini, 1967.

Venturi, Lionello. "La Data dell'attività romana di Giotto.” L'Arte, vol. 21 (1918): 229235.

Venturi, Lioinello. “La 'Navicella' di Giotto.” L'Arte, vol. 25 (1922): 49-69.

Verdon, Timothy. La Basilica di San Pietro: gli papi e gli artisti. Milano: Mondadori, 2005.

Virch, Claus. "A Page from Vasari's Book of Drawings." The Metropolitan Museum of Art Bulletin, New Series, vol. 19, no. 7 (Mar. 1961): 185-193.

Wollesen, Jens. Die Fresken von San Piero a Grado bei Pisa. Bad Oeynhausen: A. Theine, 1977.

Zimmerman, George Max. Giotto und die Kunst Italiens im Mittelalter. Leipzig: Seemann, 1899.

Zucker, Mark. "Parri Spinelli Drawings Reconsidered." Master Drawings, vol. 19, no.4 (1981): 426-441 and 471-484. 


\section{FIGURES}

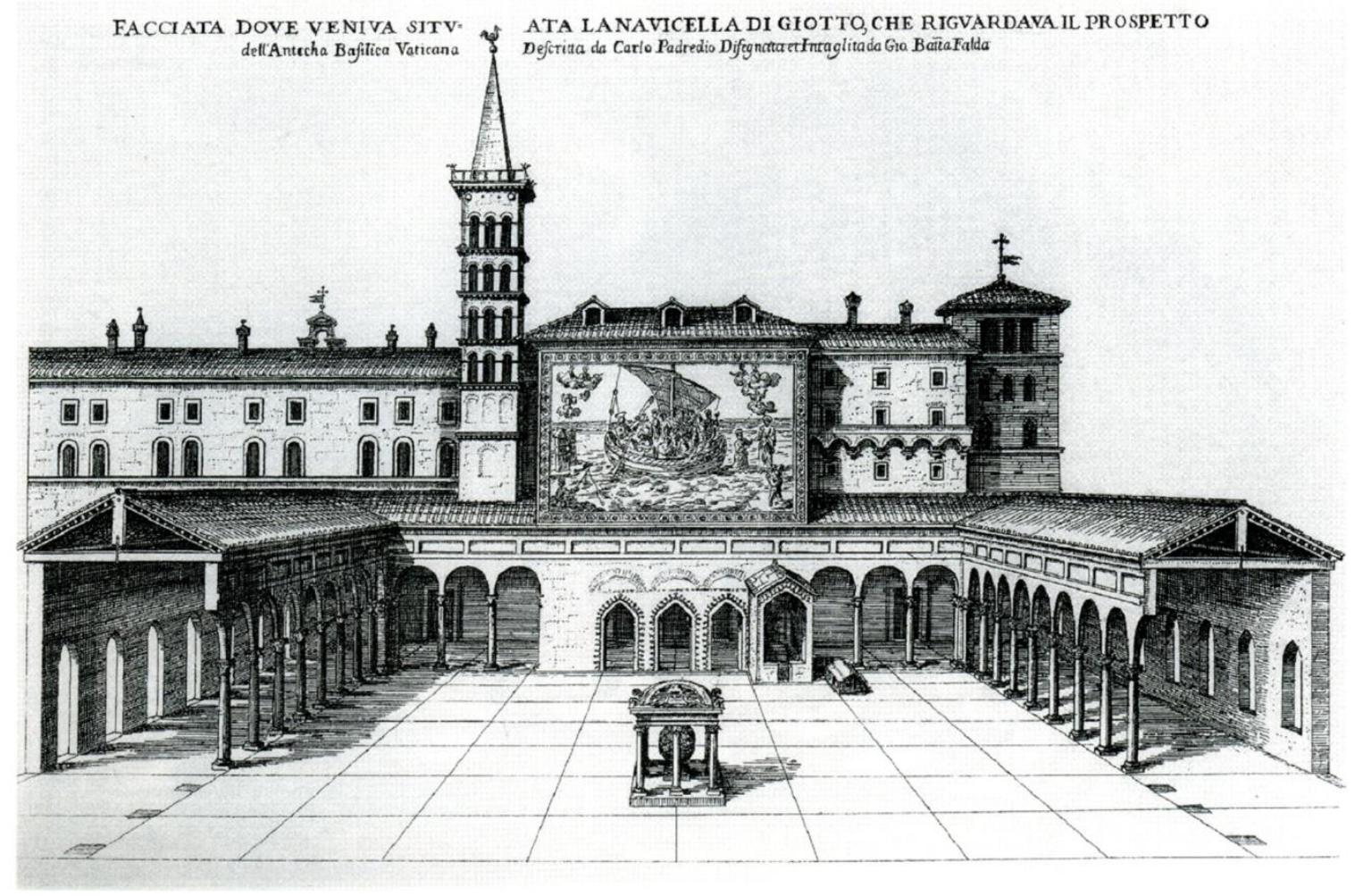

Figure 1: Giovanni Battista Falda, Reconstruction of Old St. Peter's atrium, Vatican, 1673 (engraving). 


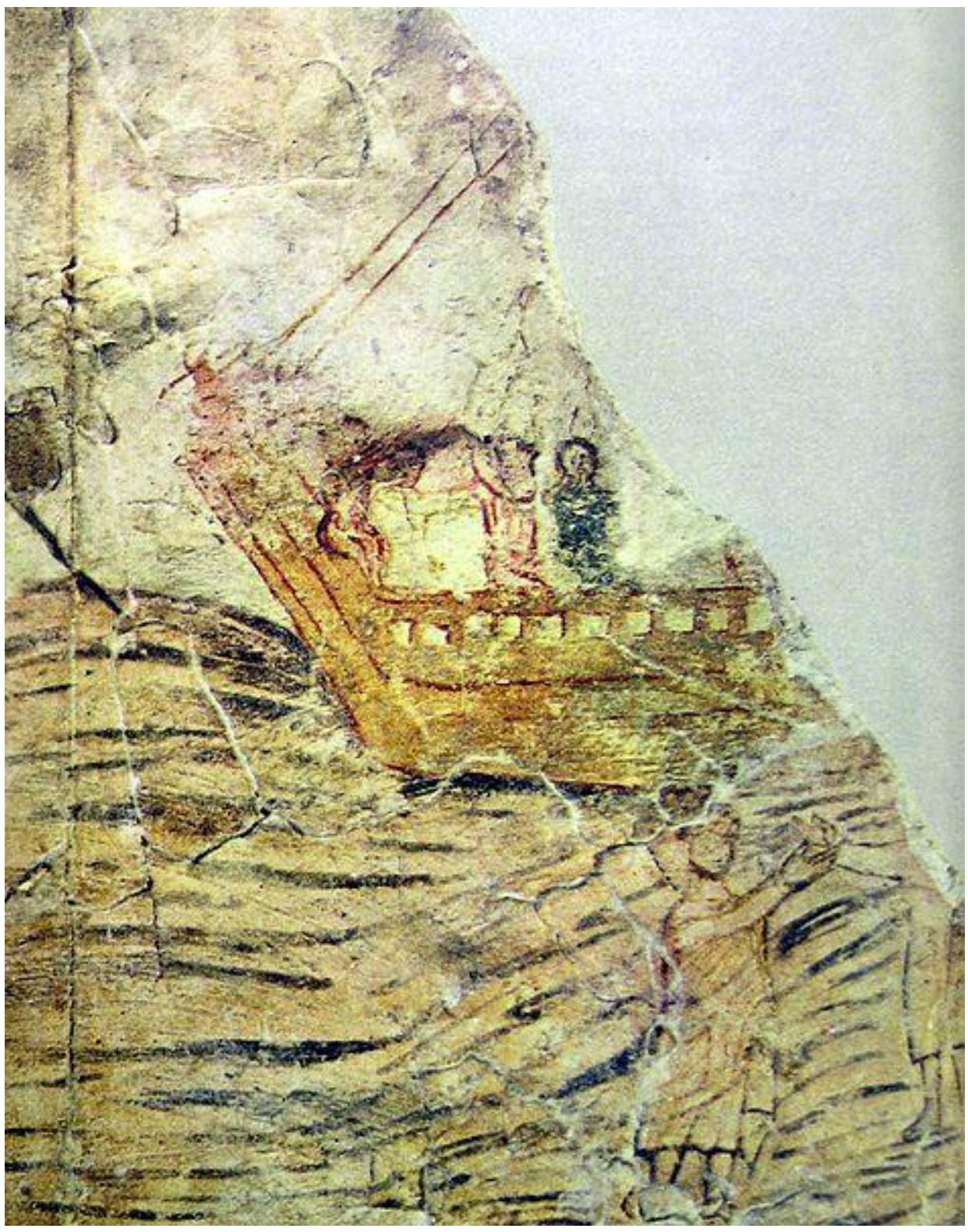

Figure 2: St. Peter rescued from the Sea of Galilee, mid-third-century, Dura Europos (fresco). 


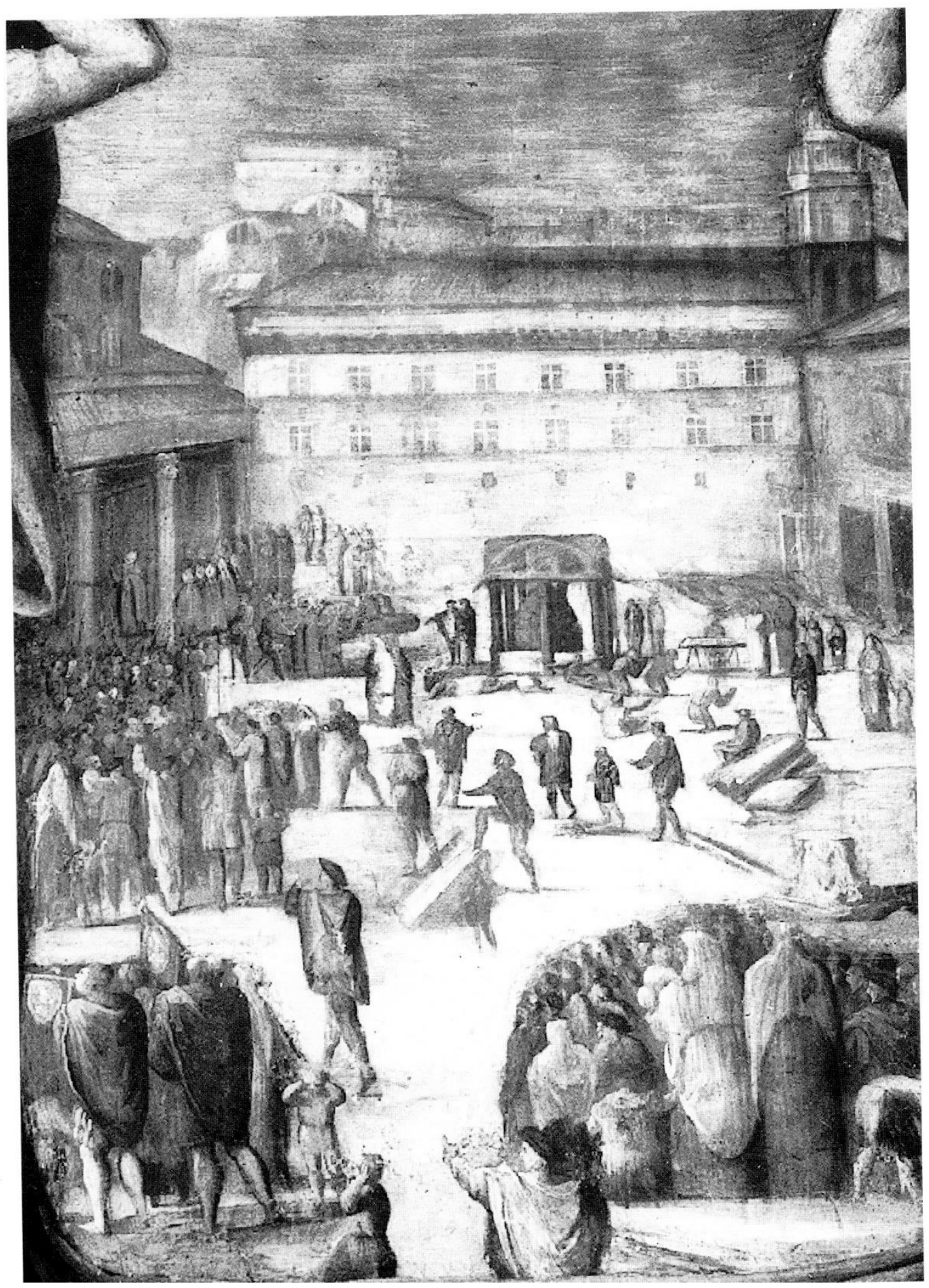

Figure 3: View of Atrium of Old St. Peter's, 1550-1555, Appartamento of Pope Julius III in the Vatican Palace (fresco). 


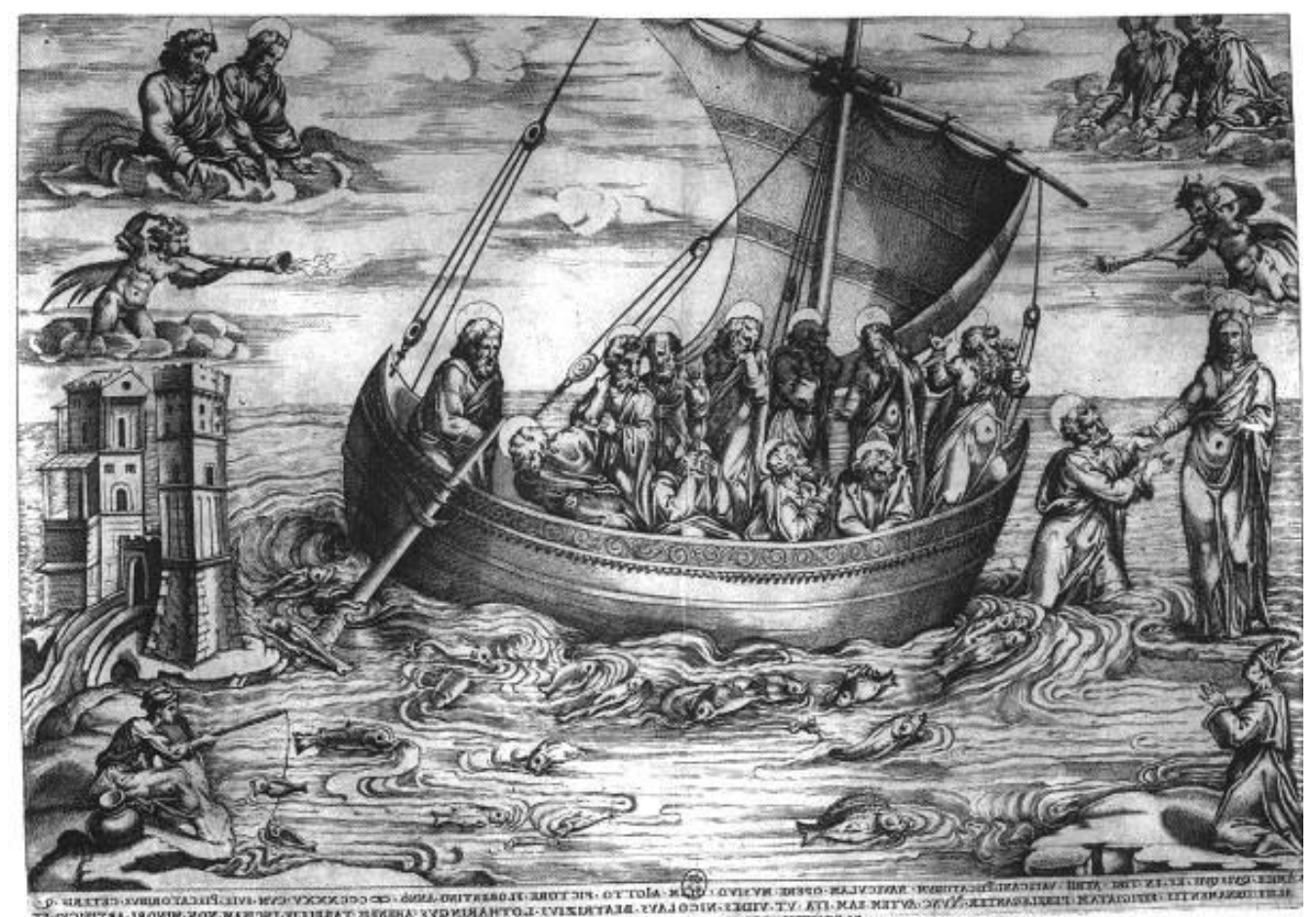

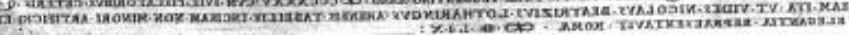

Figure 4: Nicolas Beatrizet, Copy of the Navicella (reversed), 1559, Bibliothèque Nationale in Paris (etching).

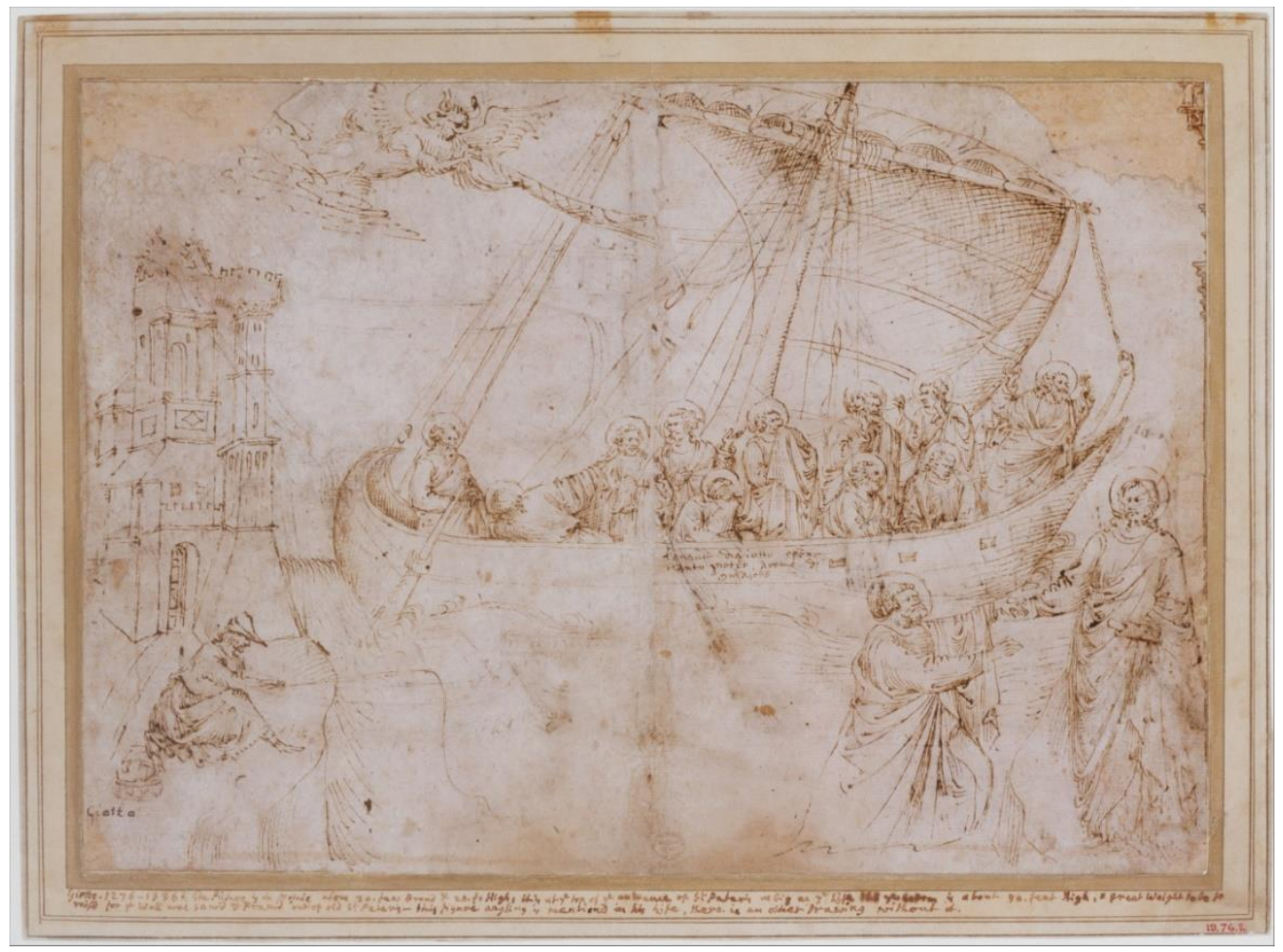

Figure 5: Parri Spinelli, Copy of the Navicella, circa 1408, Metropolitan Museum (ink). 


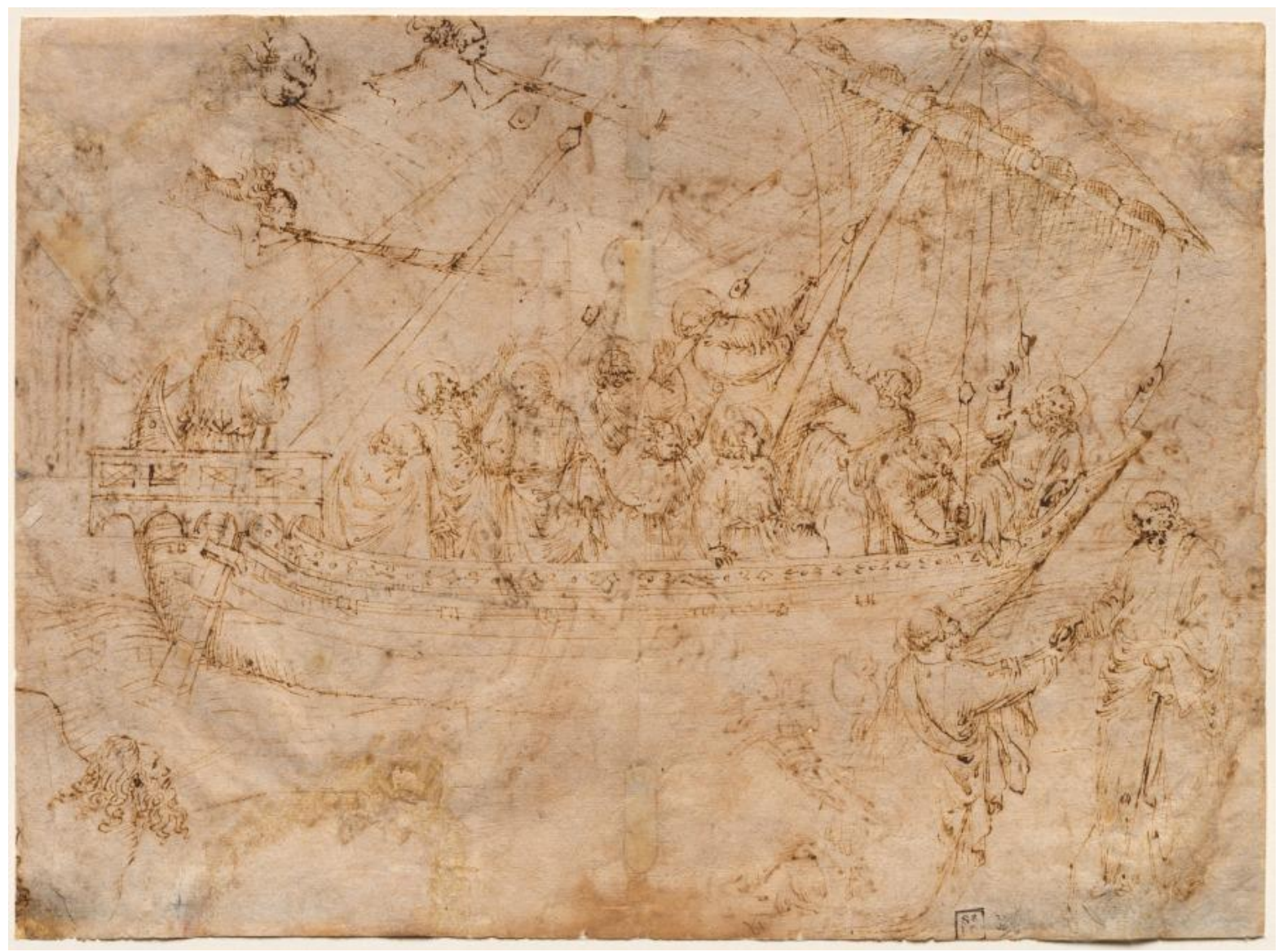

Figure 6: Parri Spinelli, Adaptation of the Navicella, circa 1408, Cleveland Museum (ink). 


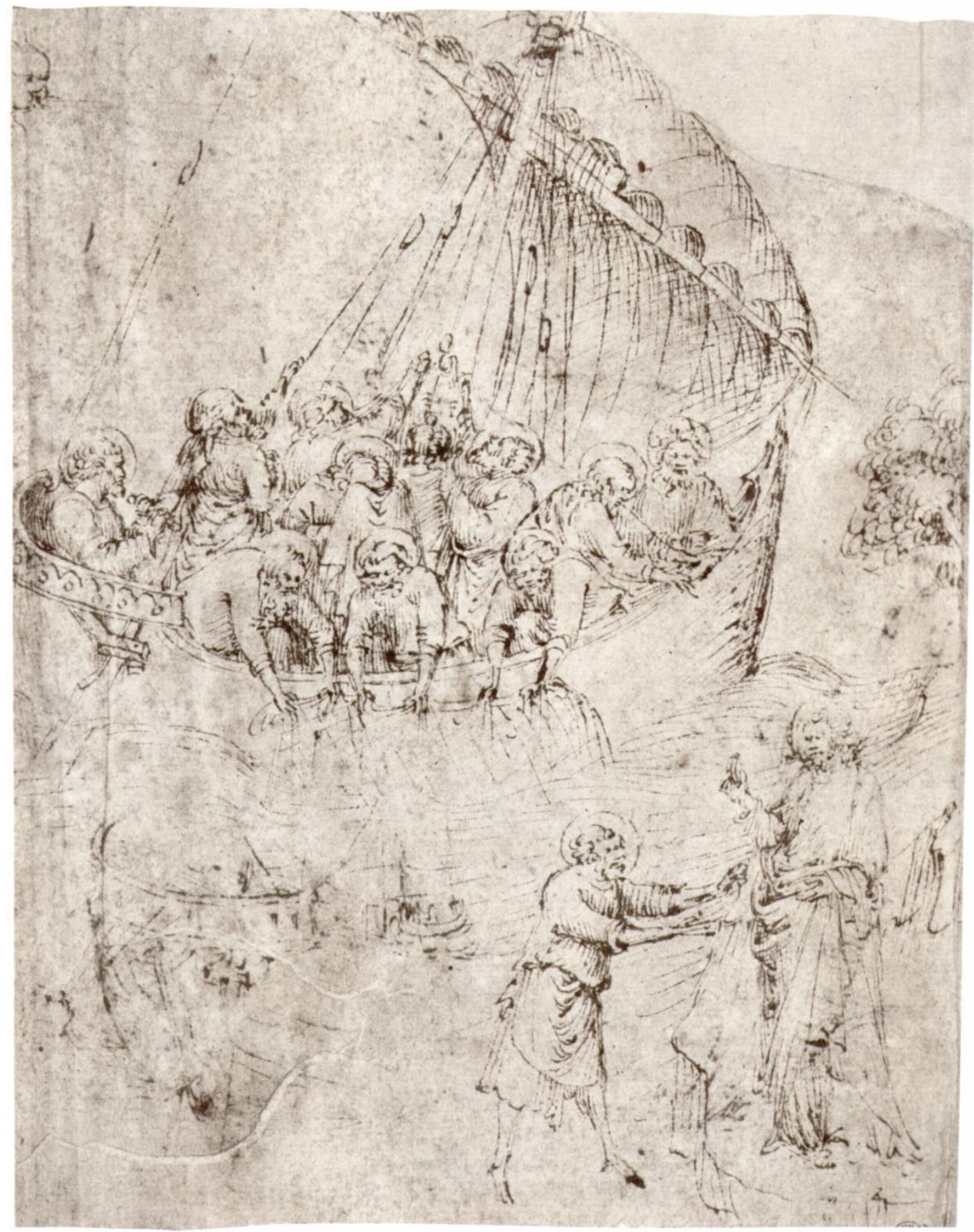

Figure 7: Parri Spinelli, Miraculous Draft of Fishes, circa 1408, Musèe Bonnat in Bayonne (ink). 


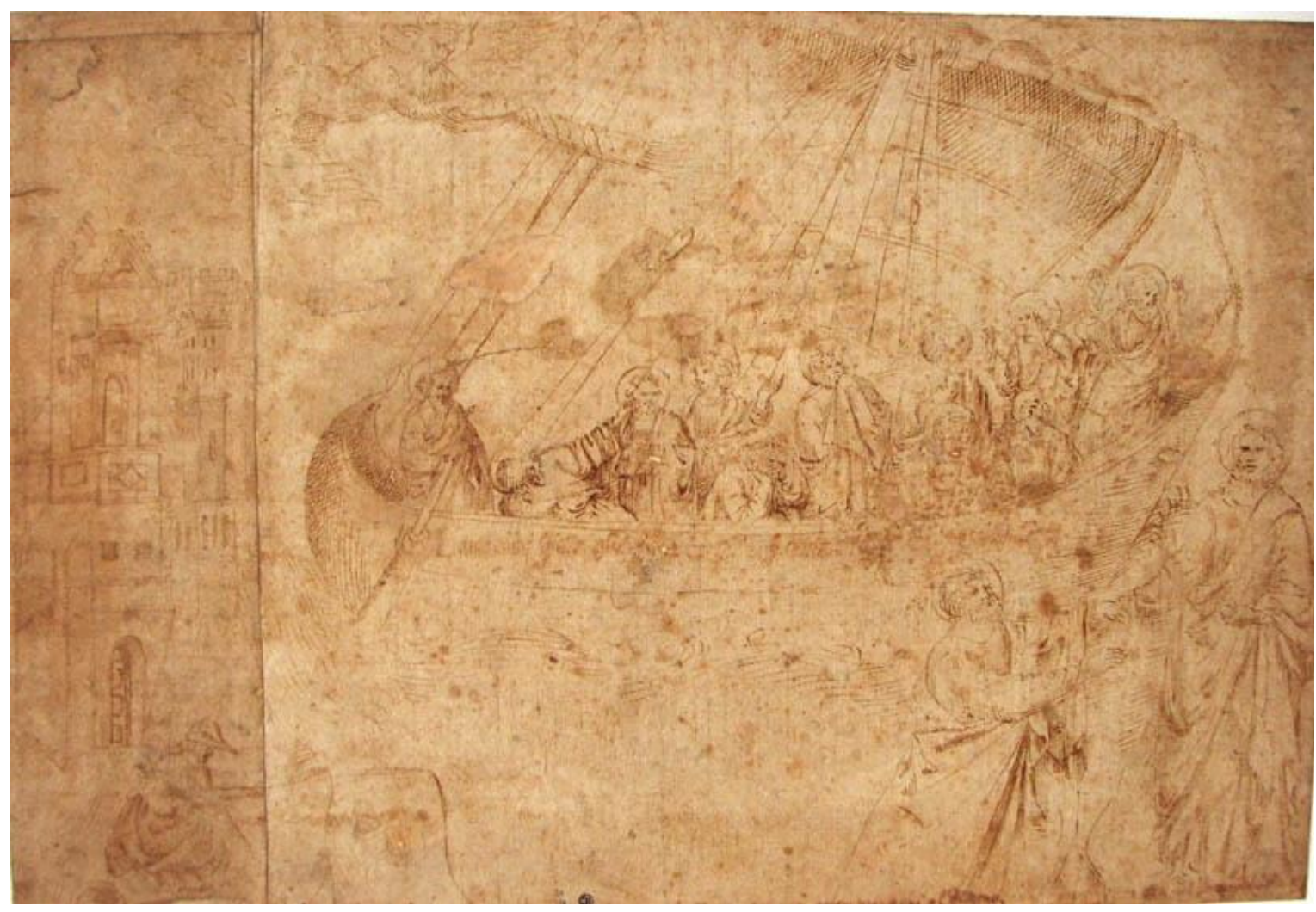

Figure 8: Parri Spinelli, Copy of the Navicella, 1400, Musèe Condè in Chantilly (ink). 


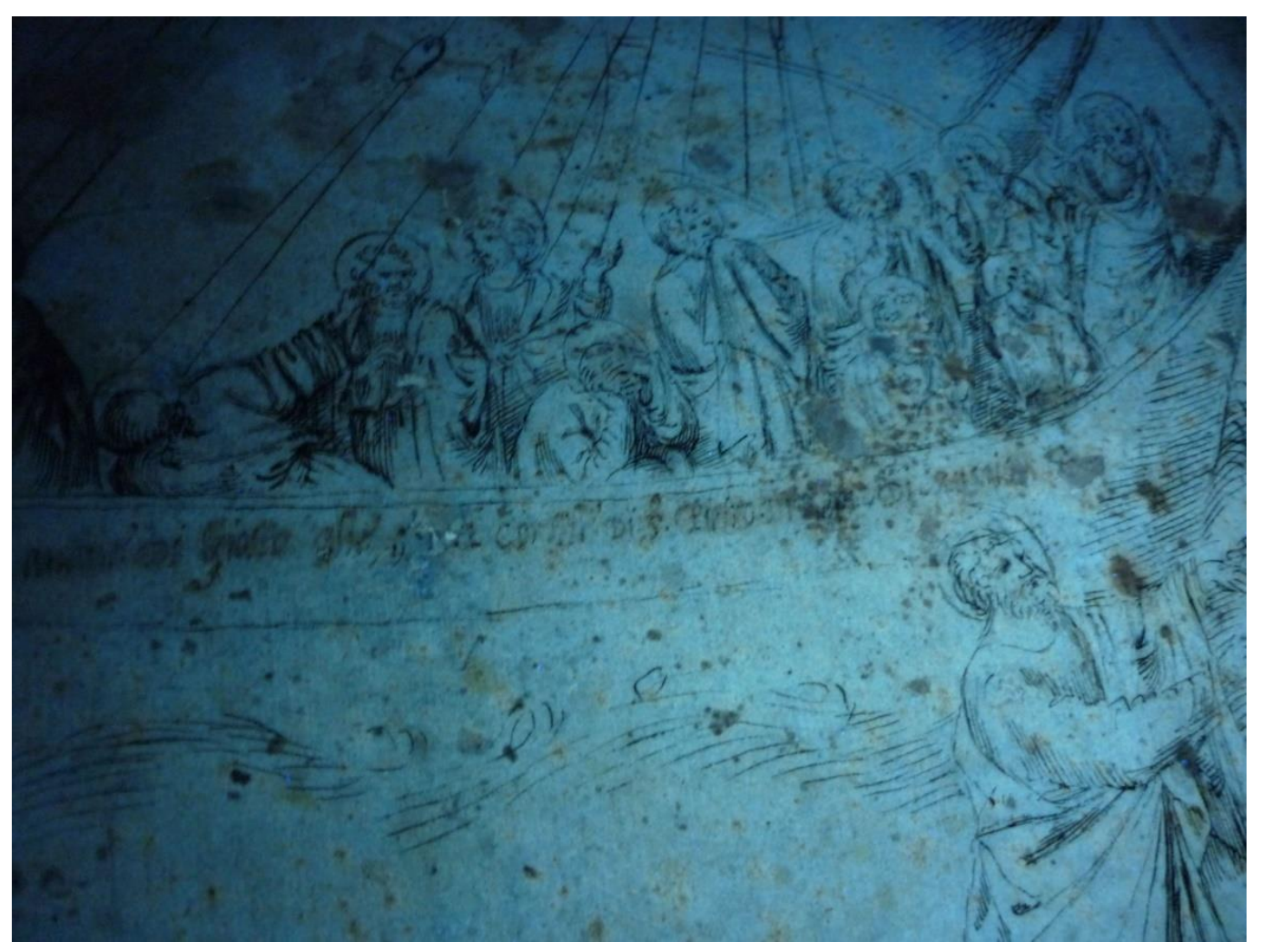

Figure 9: Detail of Figure 8 under UV lamp (courtesy of Mme. Nicole Garnier).

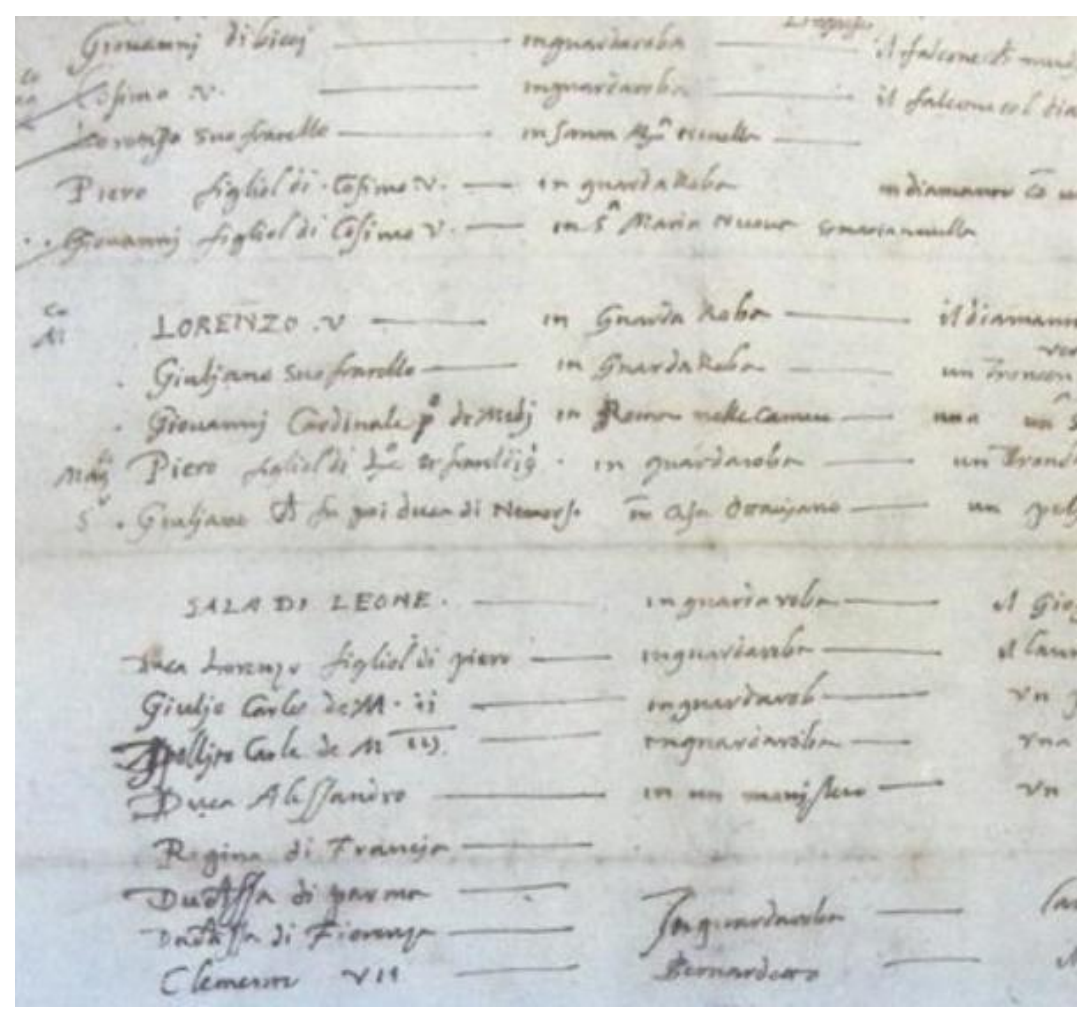

Figure 10: Giorgio Vasari, autograph notes, Archivio Vasariano di Arezzo (ink). 


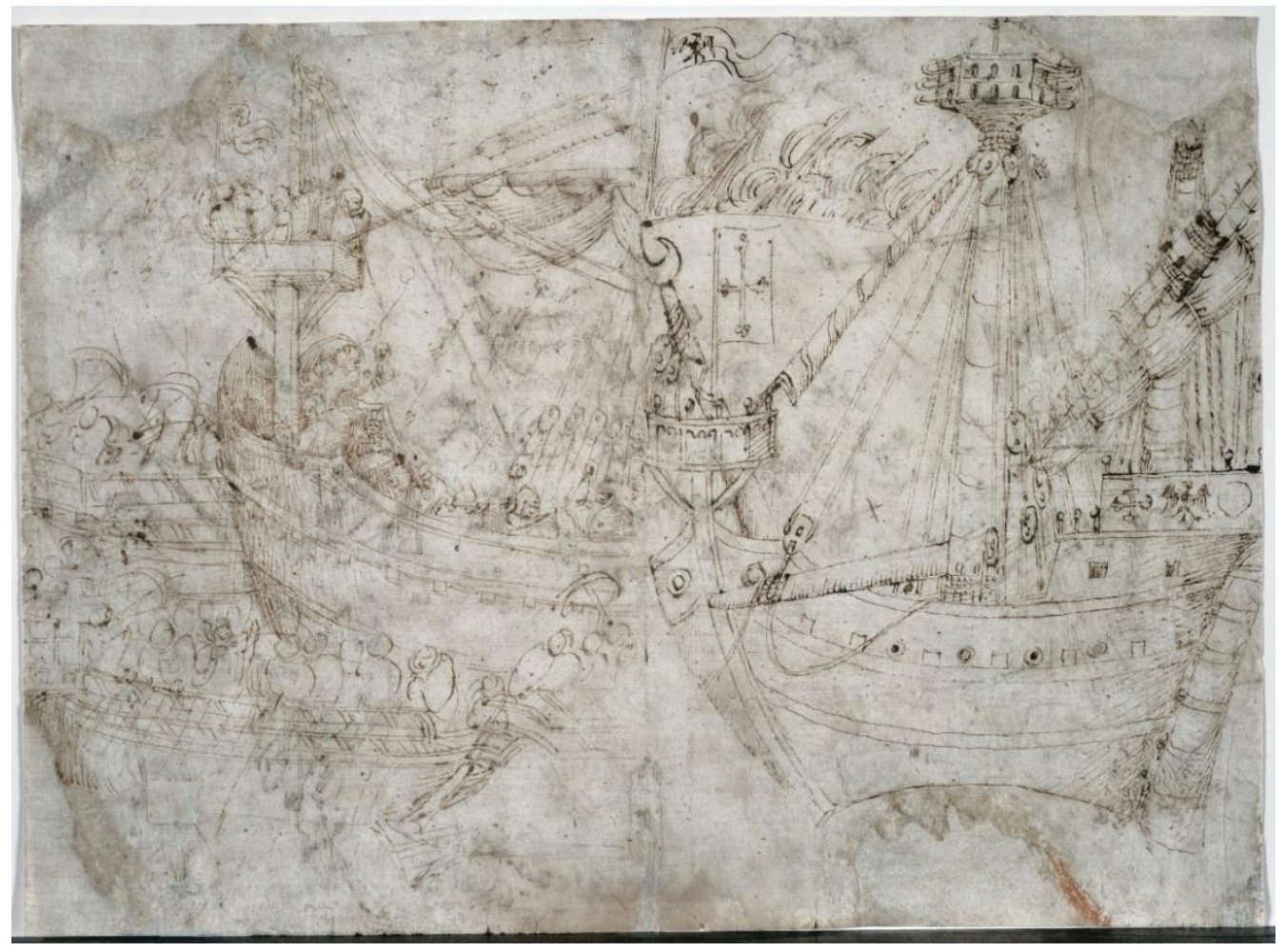

Figure 11: Parri Spinelli, sketch for Sala di Balia fresco (verso of Figure 6), circa 1408 (ink).

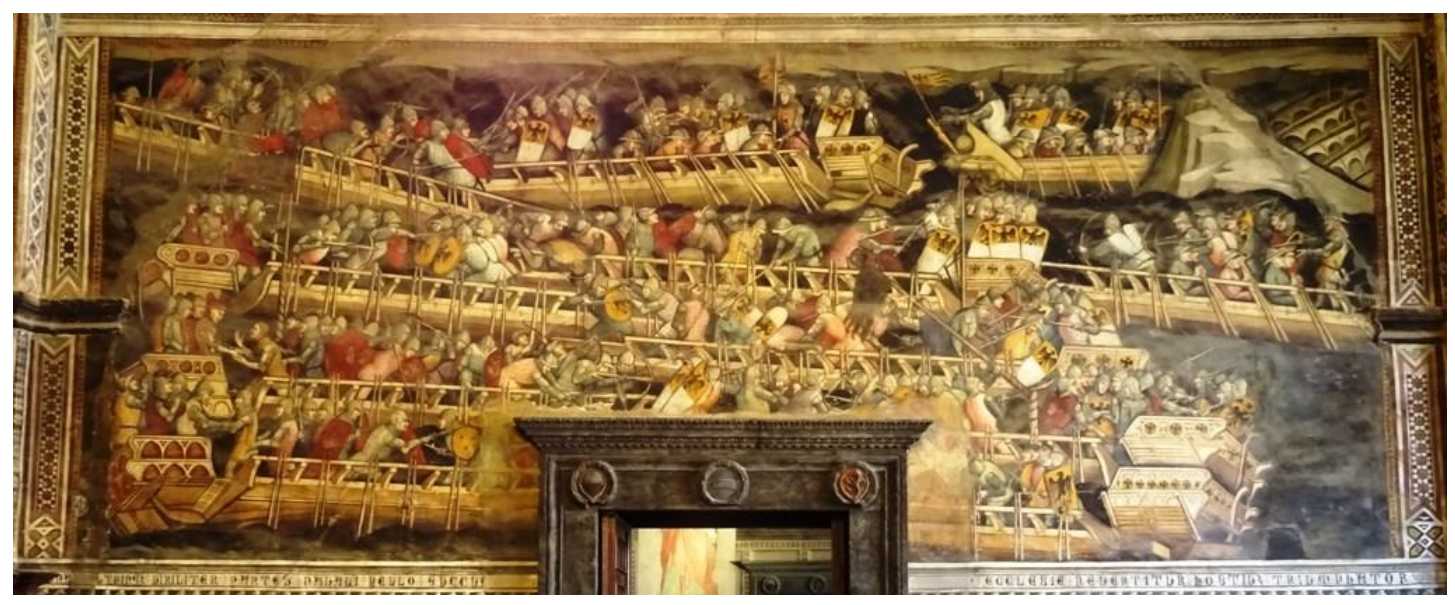

Figure 12: Spinello Aretino, Naval Battle, Sala di Balia in Siena, 1408 (fresco). 


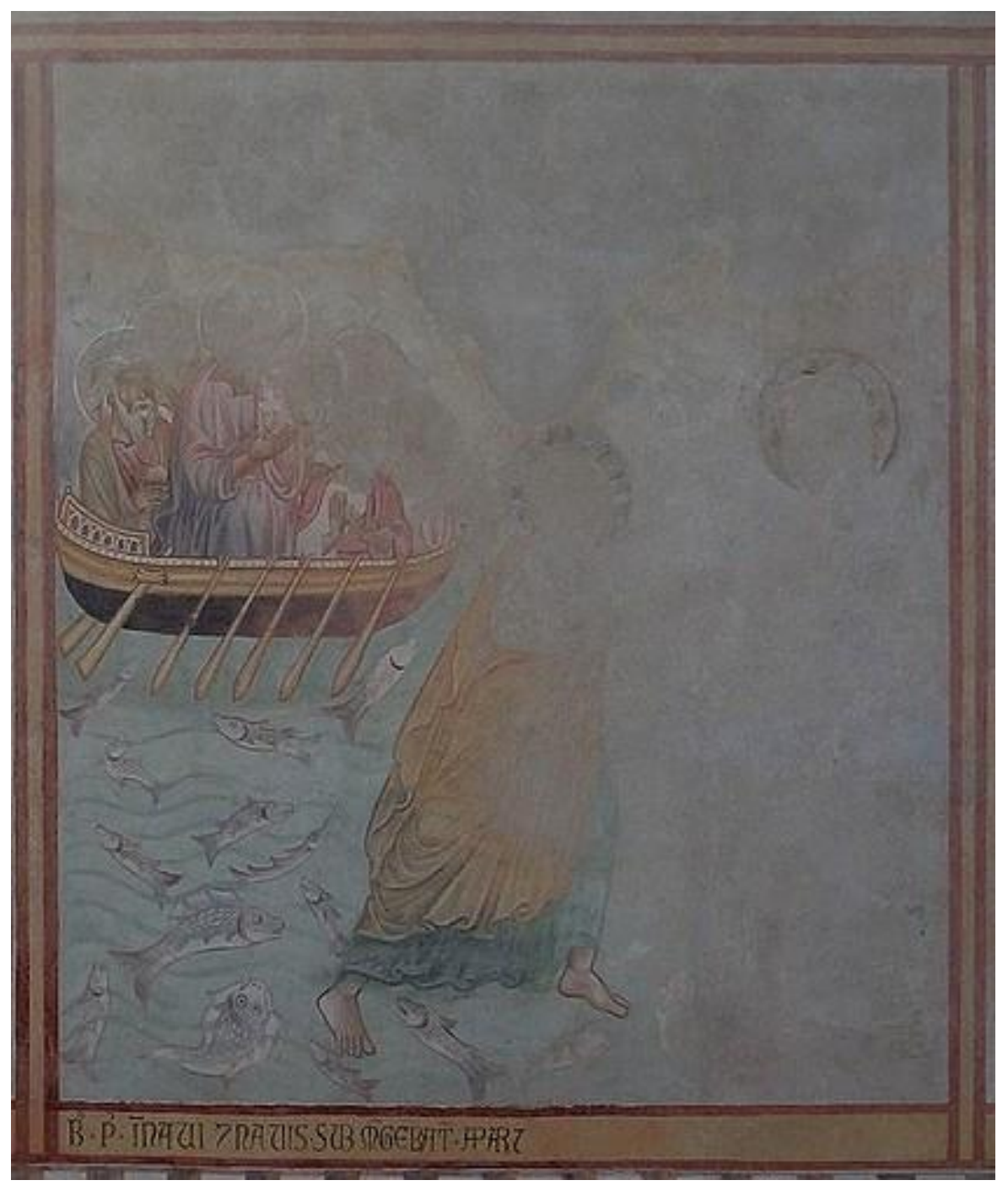

Figure 13: Deodato Orlandi, Adaptation of the Navicella, San Piero a Grado in Pisa, circa 1300 (fresco). 


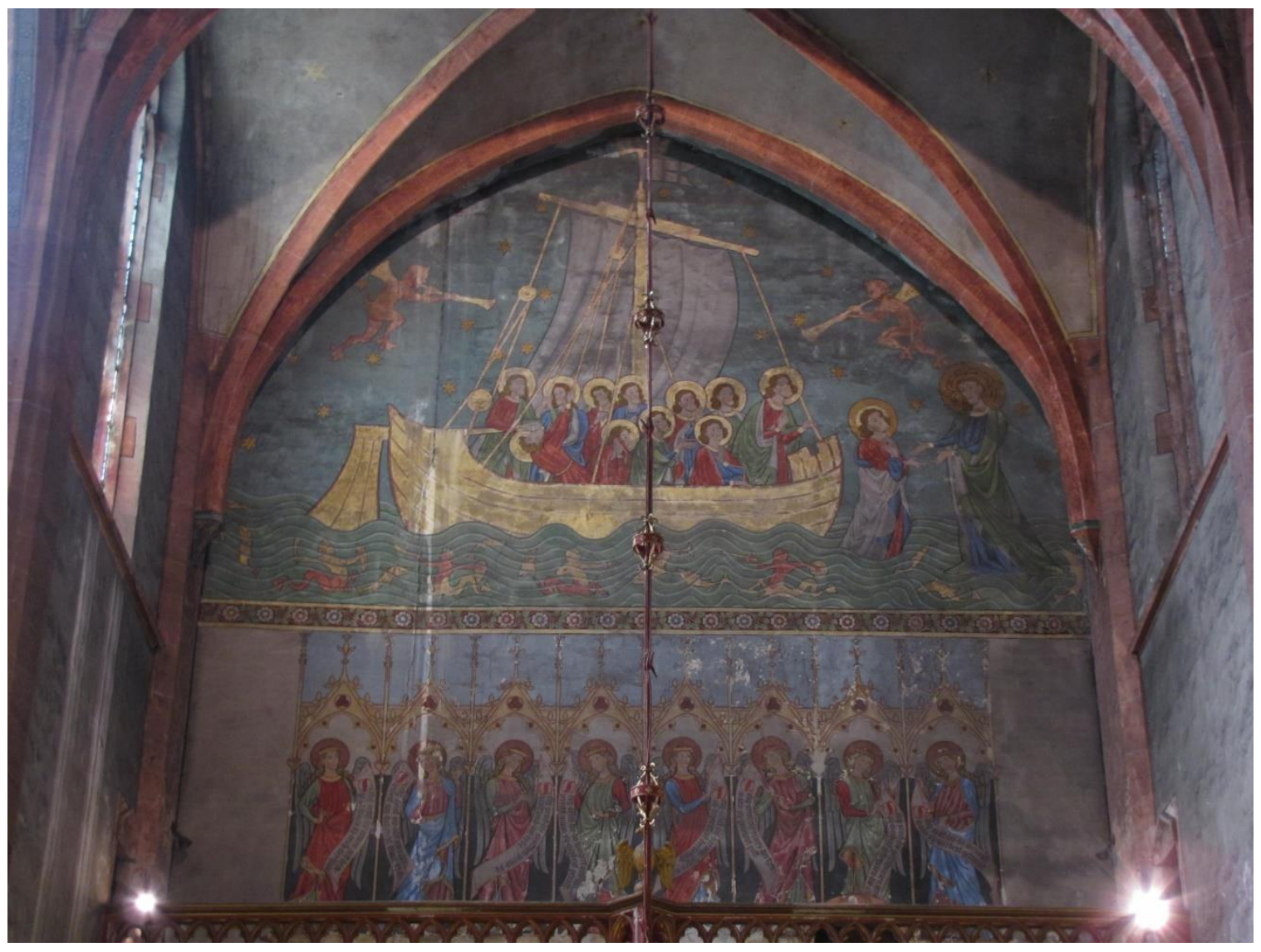

Figure 14: Adaptation of Navicella, Saint-Pierre-la-Jeune in Strasbourg, circa 1320 (fresco) 


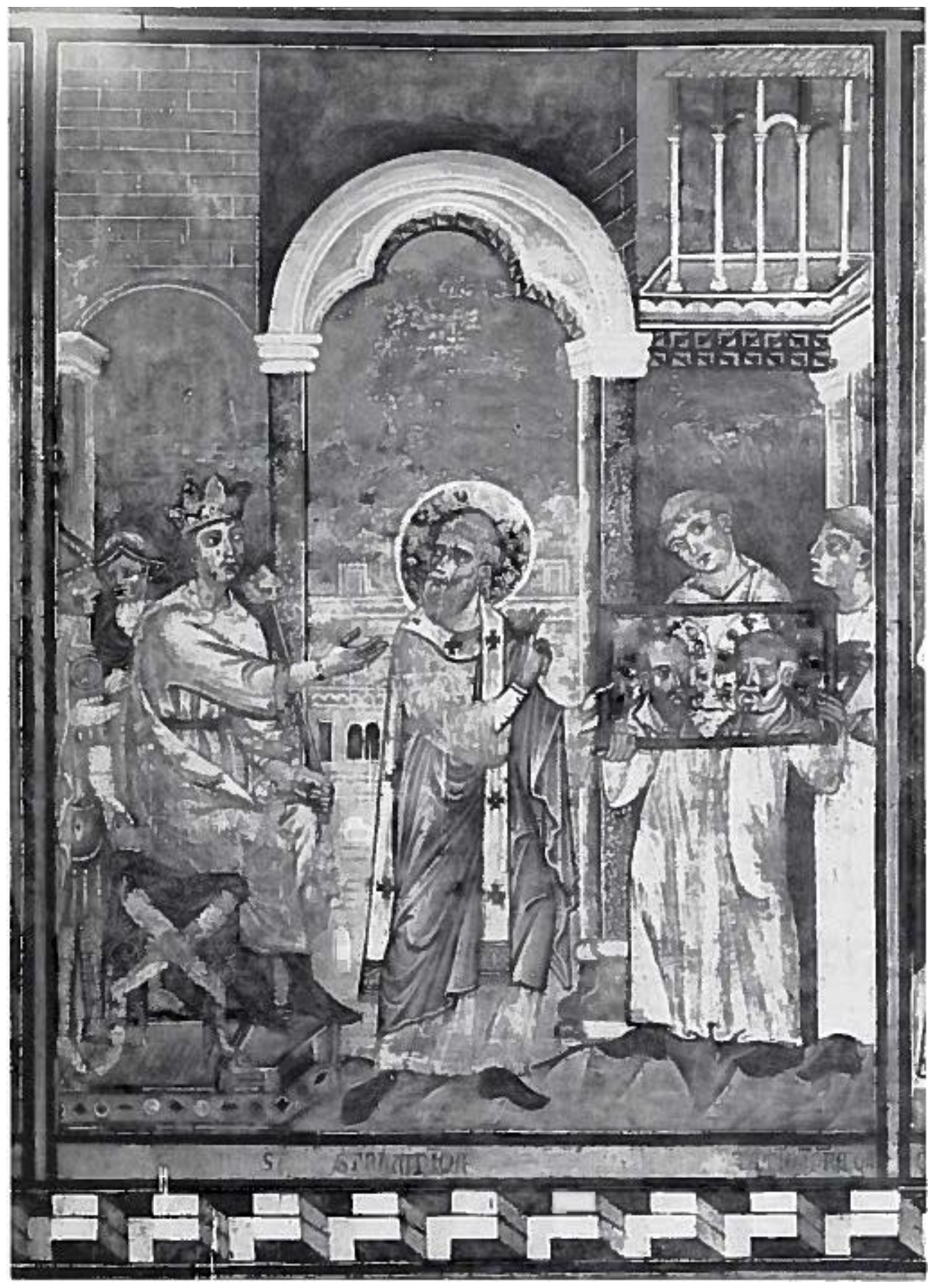

Figure 15: Deodato Orlandi, Constanine, Pope Sylvester, and icon of Ss. Peter and Paul, San Piero a Grado in Pisa, circa 1300 (fresco). 


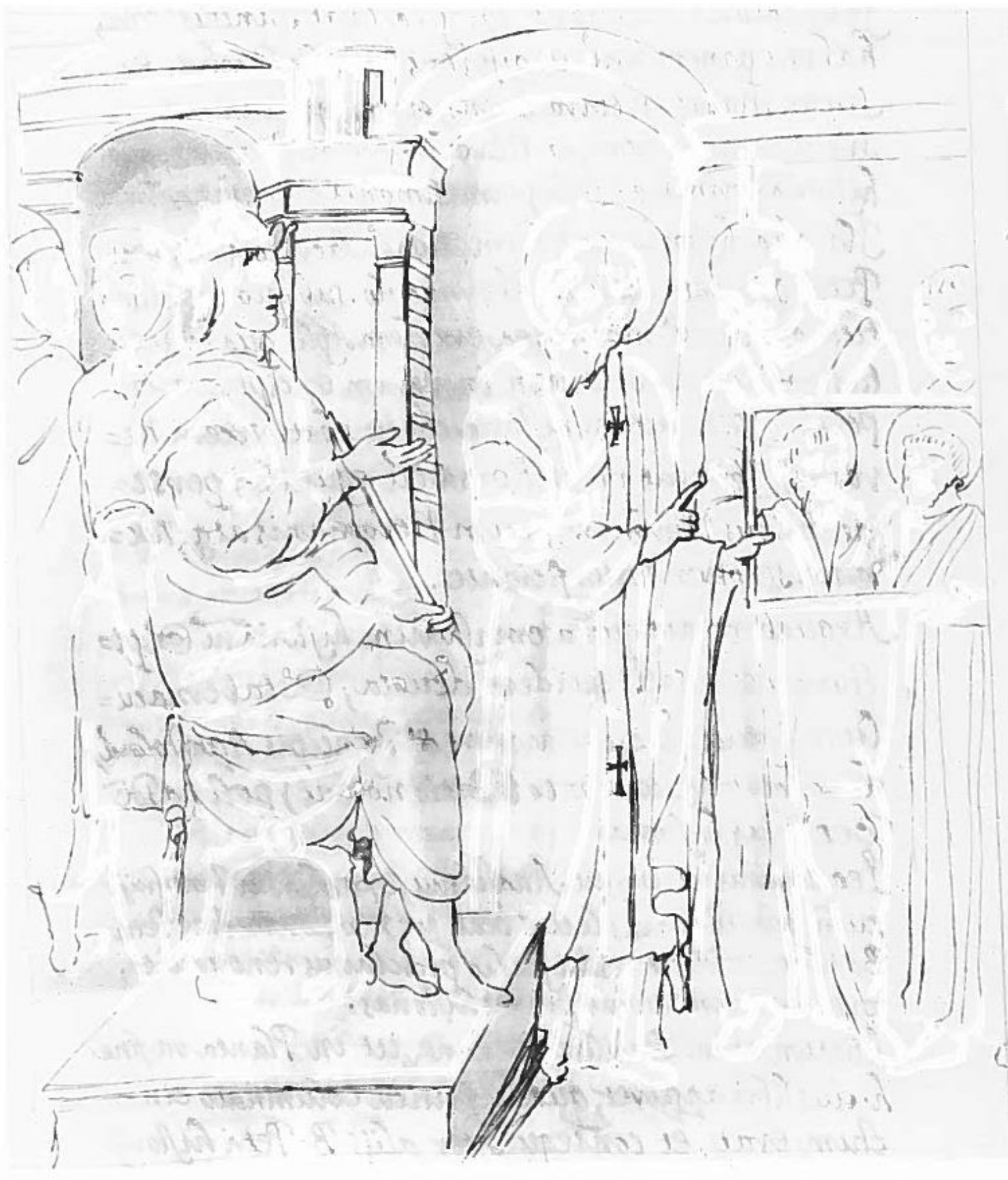

Figure 16: Giacomo Grimaldi, Copy of fresco from atrium of Old St. Peter's representing Constanine and Pope Sylvester with icon of Ss. Peter and Paul, circa 1600 (ink). 


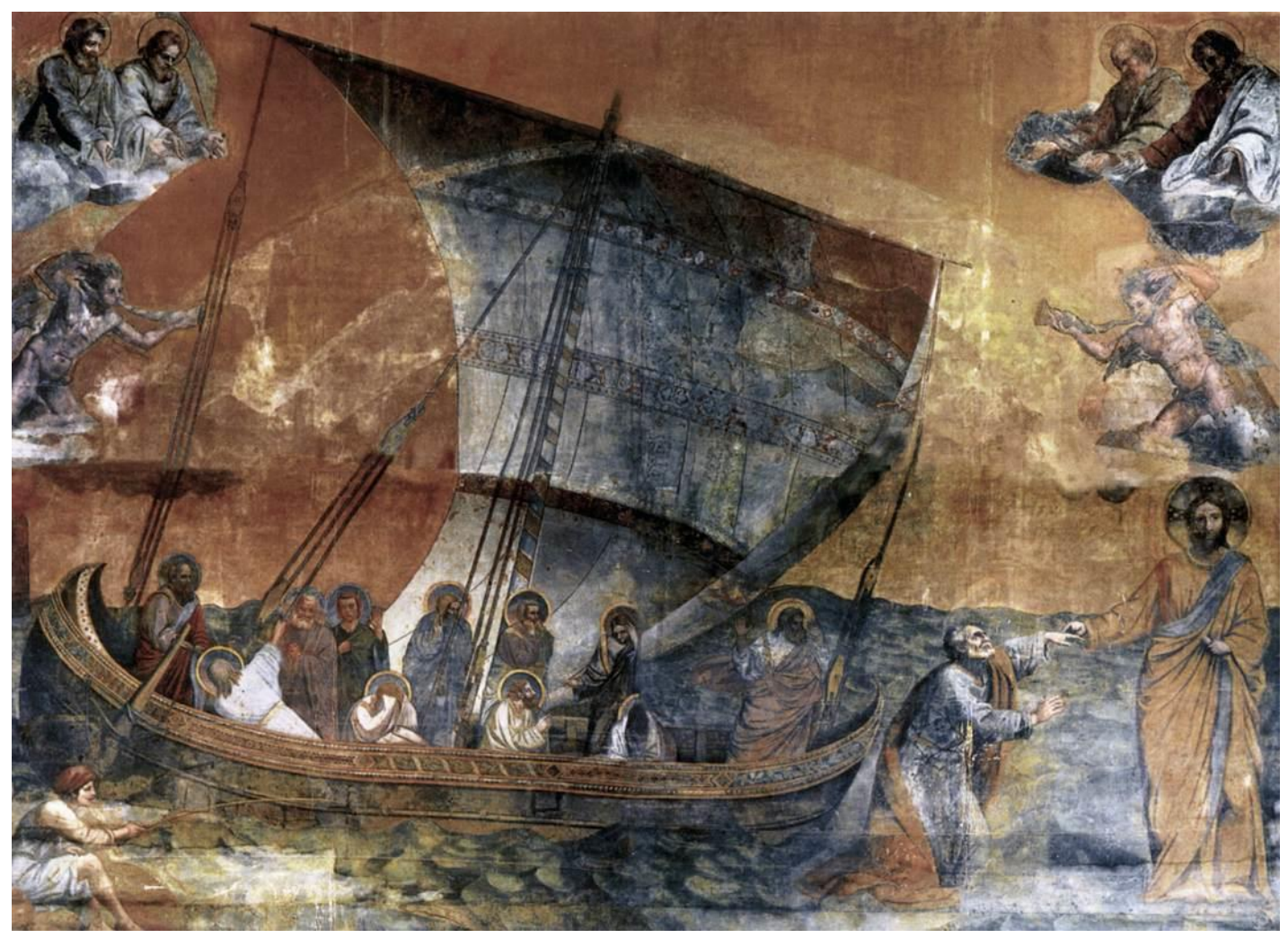

Figure 17: Francesco Berretta, Copy of Navicella, Reverenda Fabbrica di S. Pietro in Vaticano, 1629 (oil on canvas). 


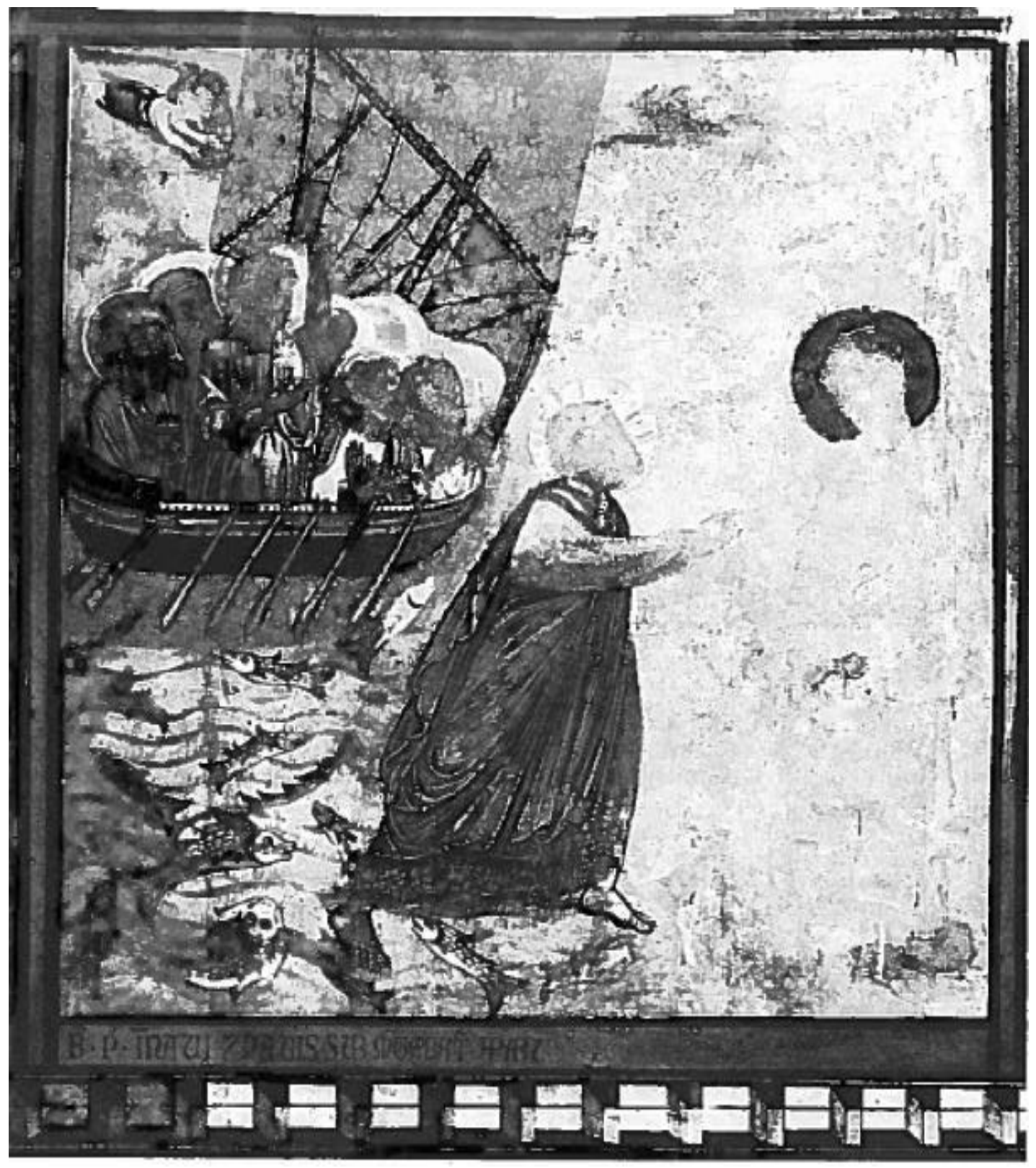

Figure 18: Hypothetical reconstruction of Figure 13. 


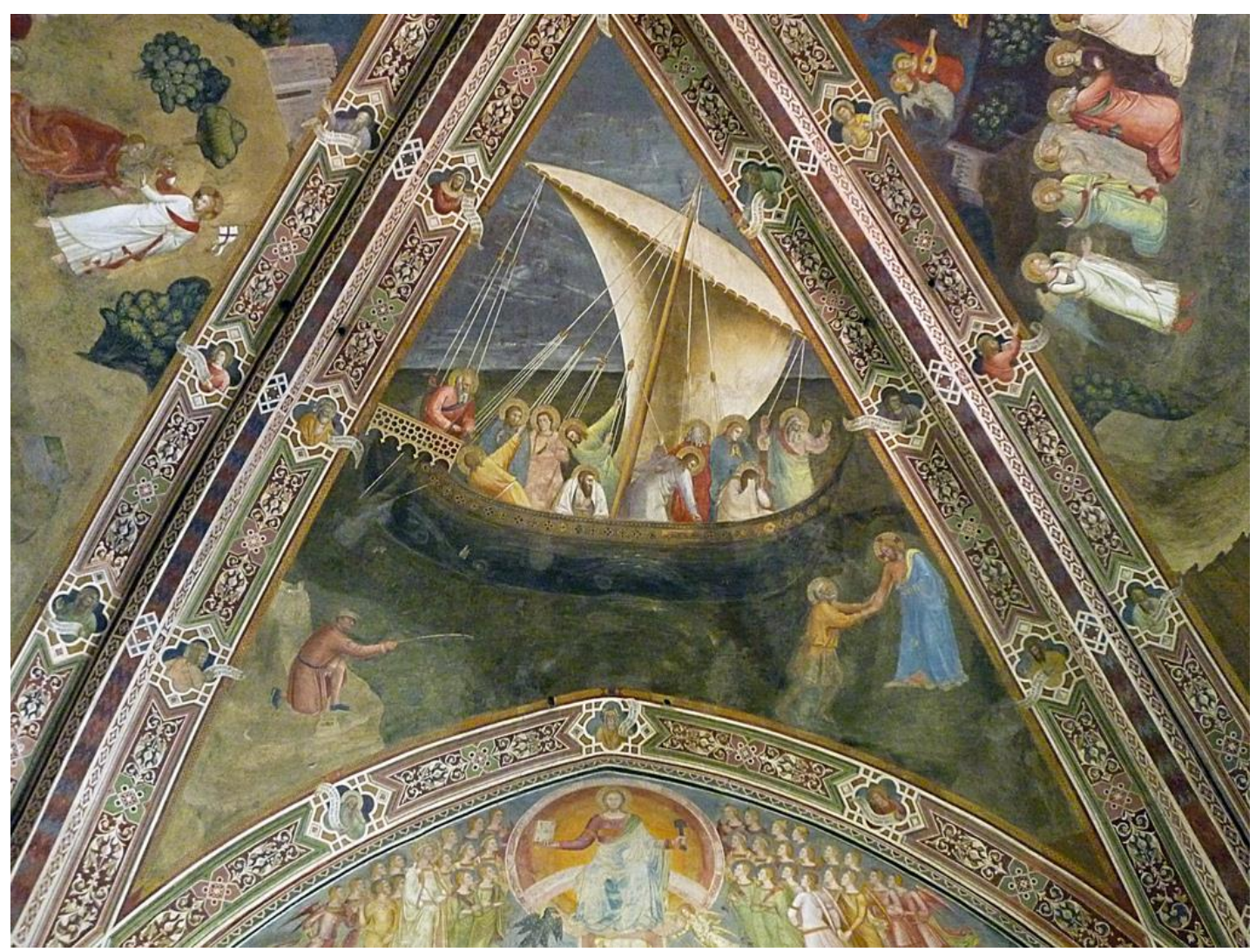

Figure 19: Andrea di Bonaiuto, Adaptation of Navicella, S. Maria Novella in Florence, circa 1365 (fresco). 


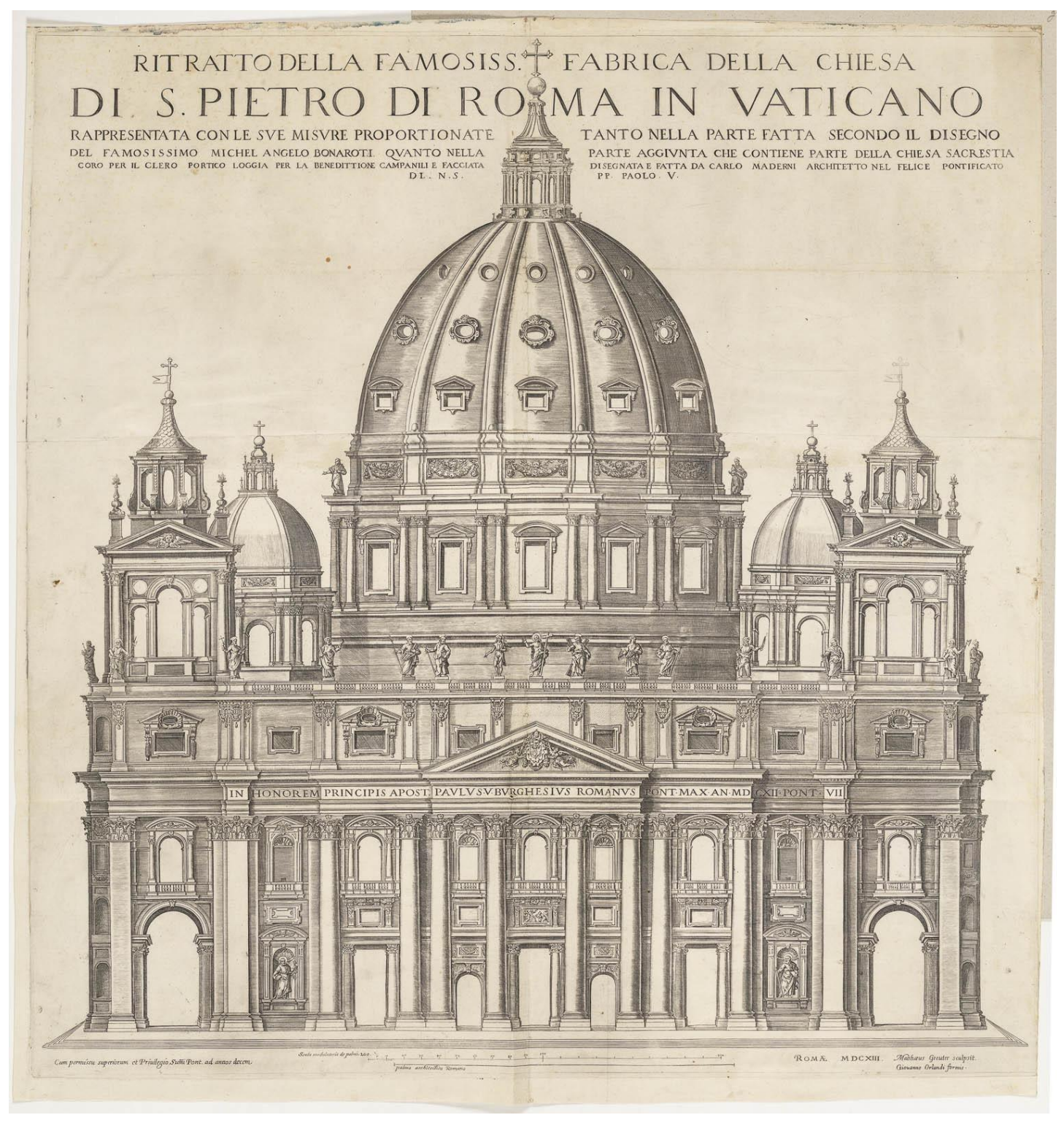

Figure 20: Matthäus Greuter, Façade of New St. Peter's, Statens Museum for Kunst in Denmark, 1613 (engraving). 


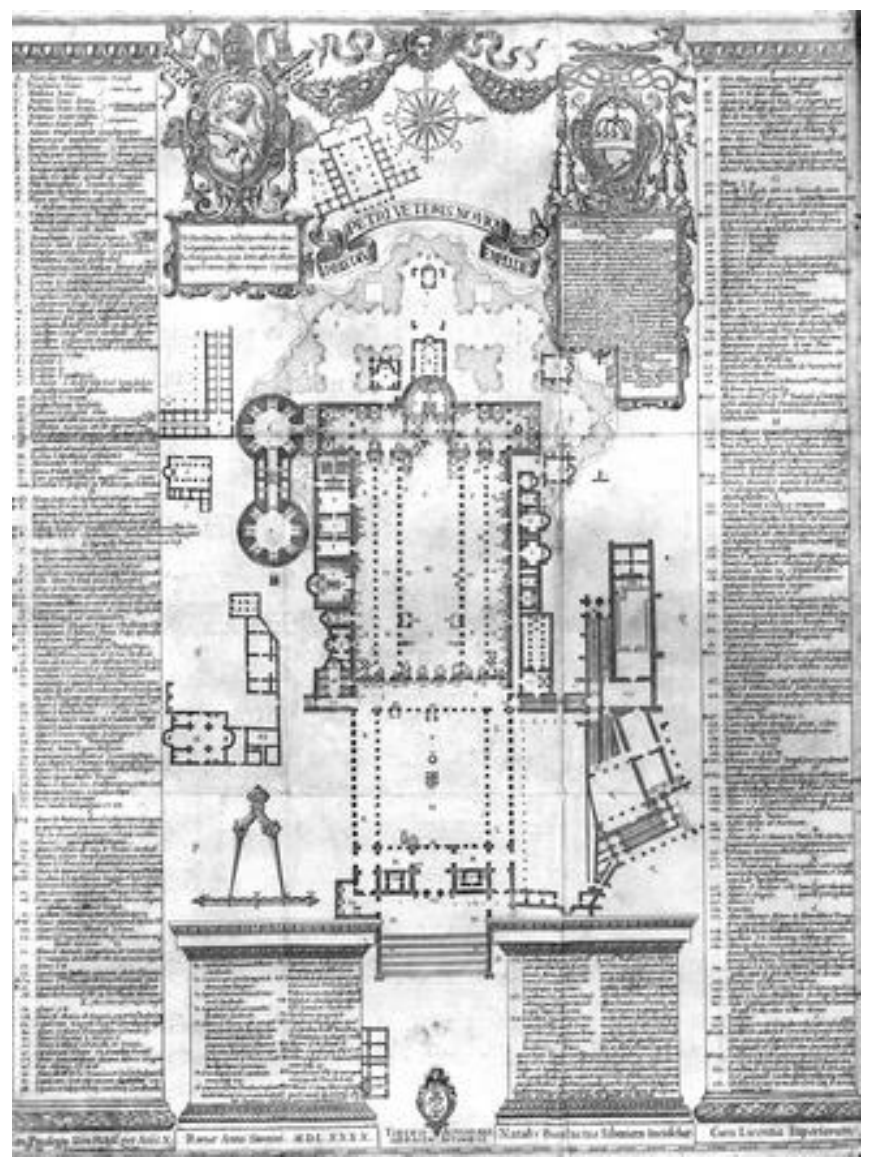

Figure 21: Natale Bonifacio, Plan of Old St. Peter's (after design by Tiberio Alfarano), 1589 (engraving).

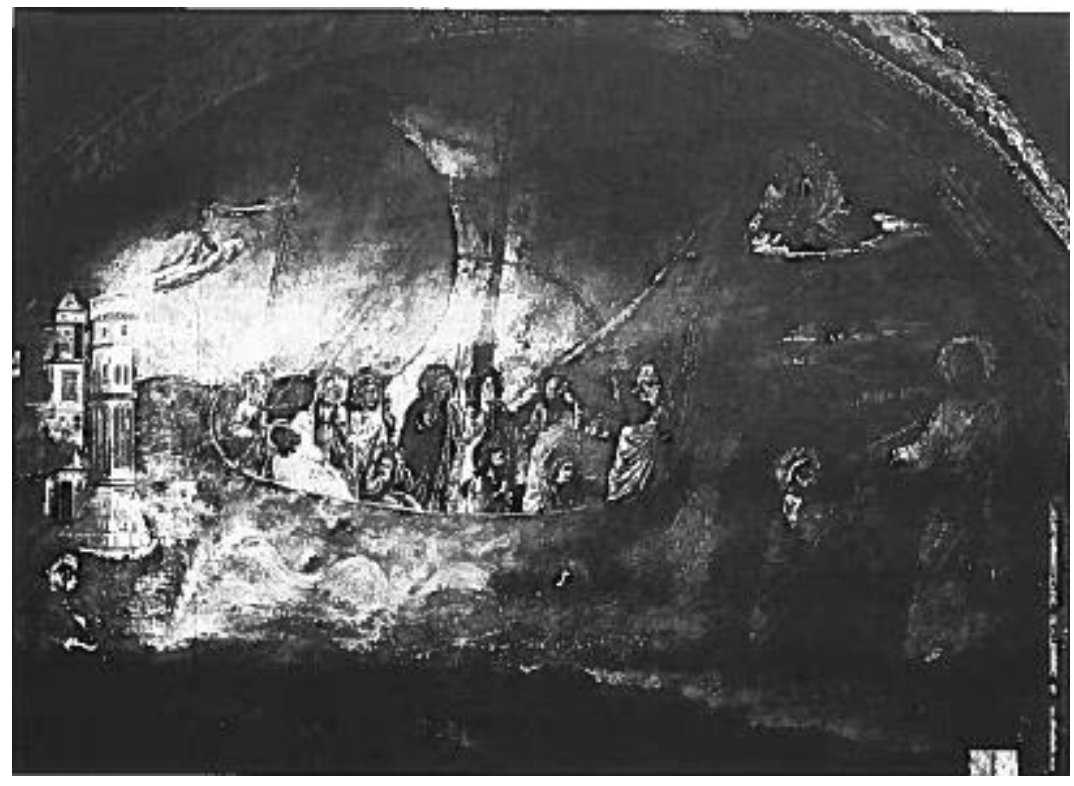

Figure 22: Nicoló Alunno, Adaptation of Navicella, S. Maria in Campis in Foligno, second half of fifteenth-century (fresco). 


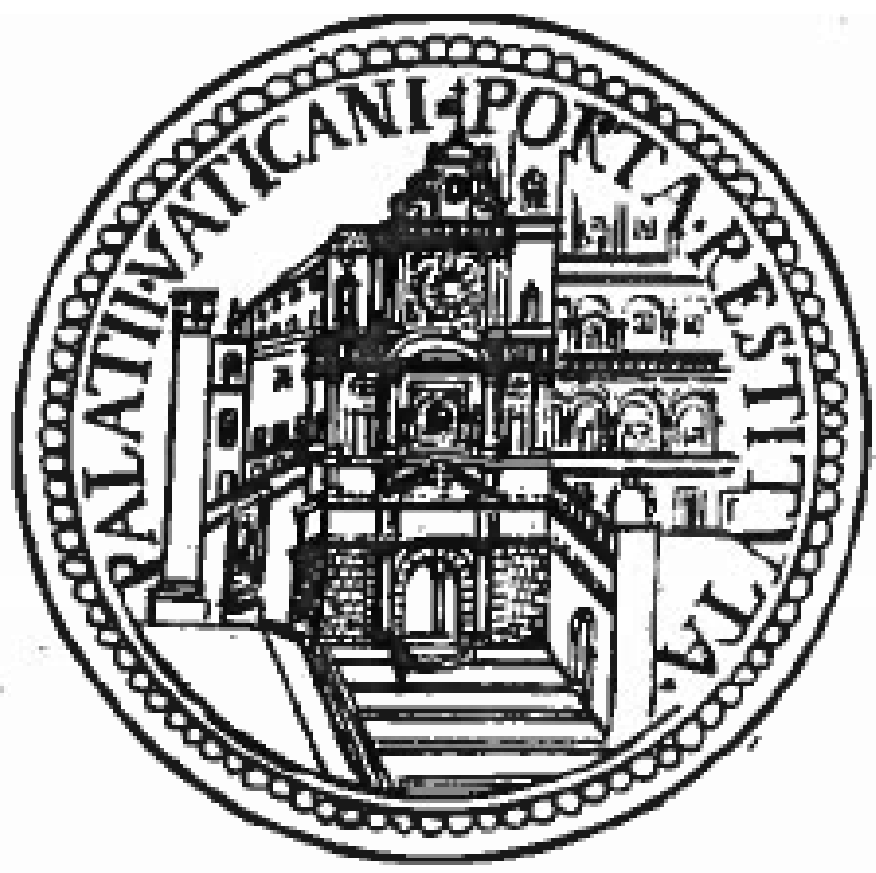

Figure 23: Filippo Bonanni, copy of Medal of Pope Paul V from Numismata Pontificum Romanorum qua a tempore Martini V. usque ad annum MDCXCIX, 1706. 


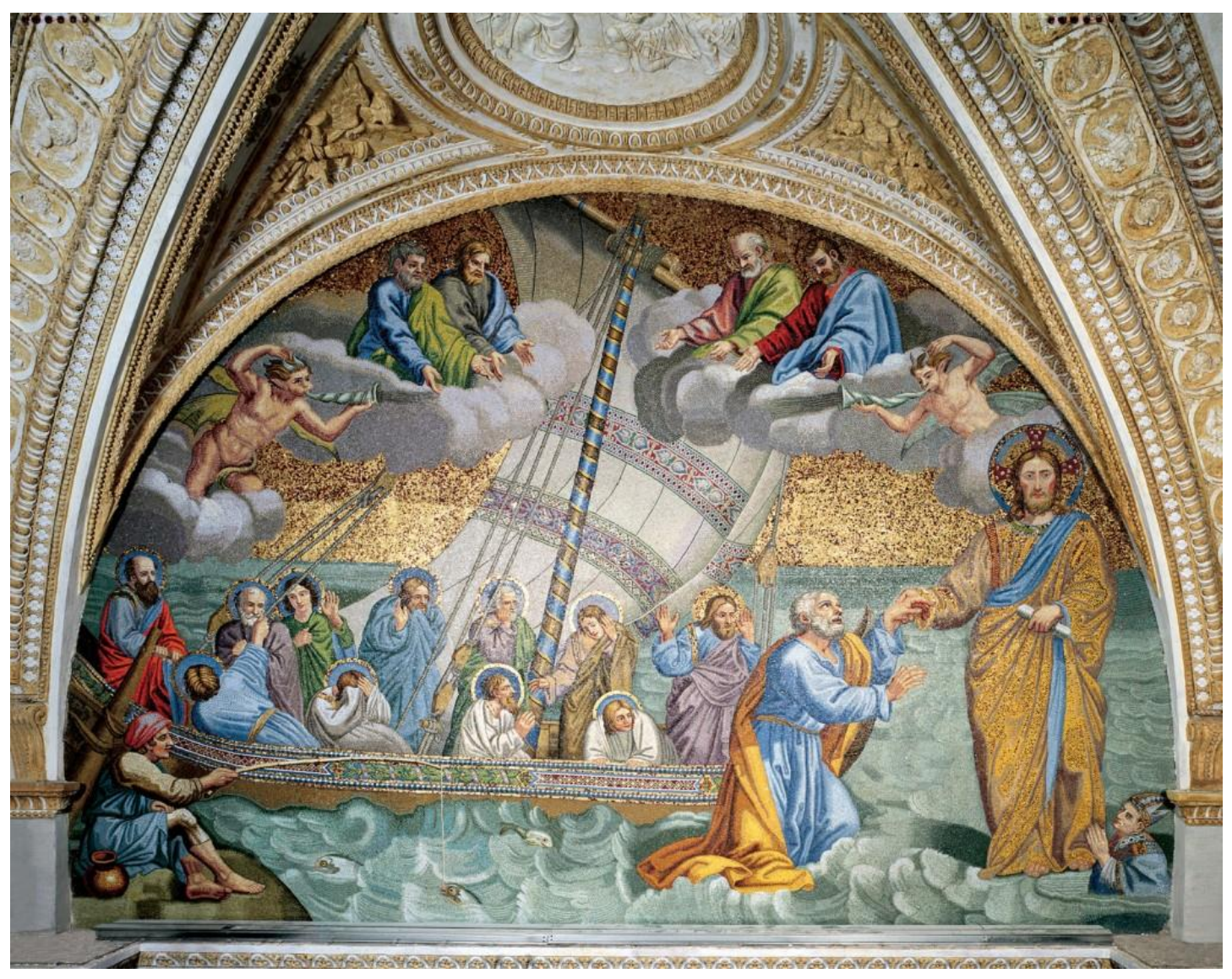

Figure 24: Orazio Manenti, Navicella, Narthex of New St. Peter's in the Vatican, 1674-5 (mosaic). 


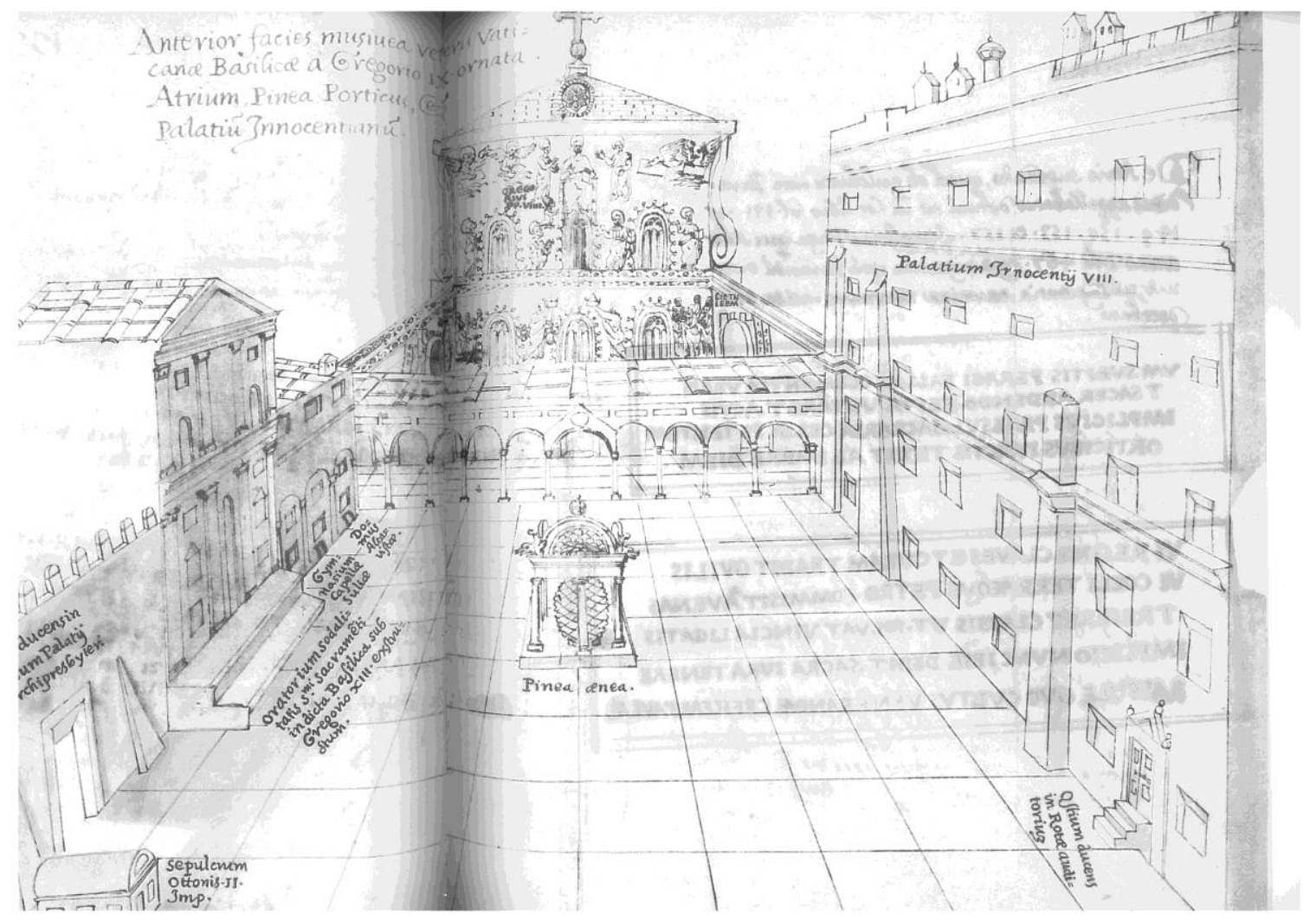

Figure 25: Giacomo Grimaldi, View of atrium of Old St. Peter's, circa 1600 (ink).

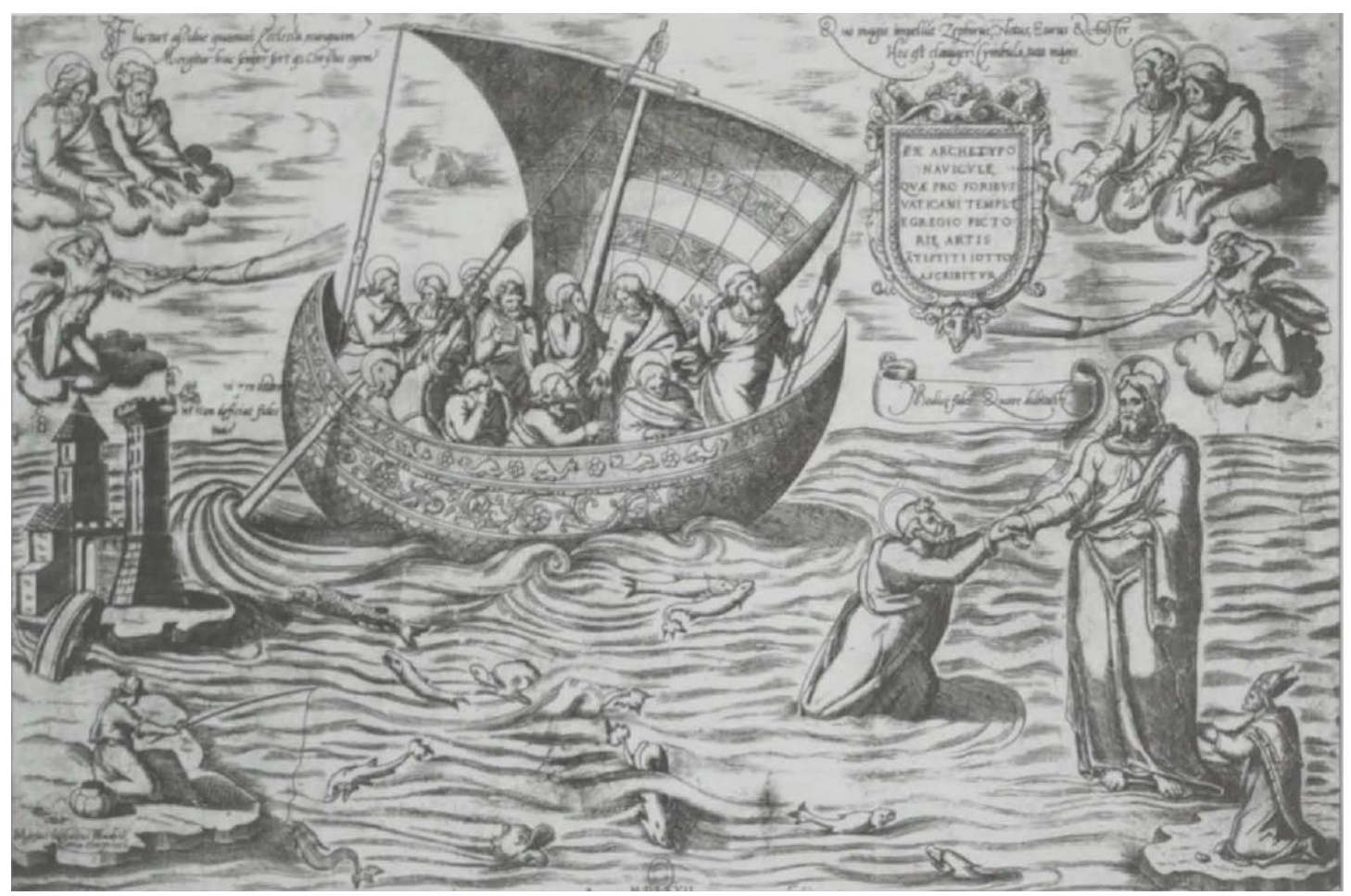

Figure 26: Mario Labacco, Copy of Navicella, Budapest, 1567 (engraving). 


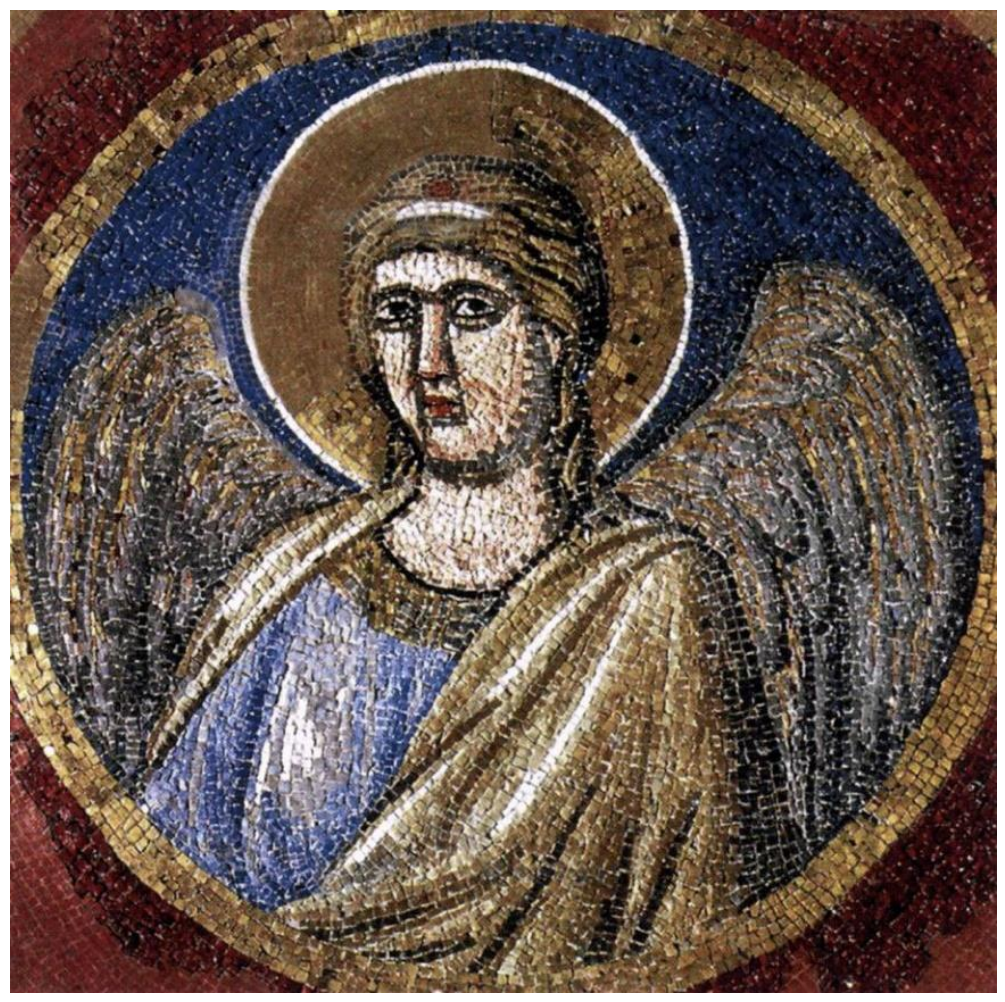

Figure 27: Bust of Angel from decorative frame of the Navicella, Vatican Grottoes (mosaic).

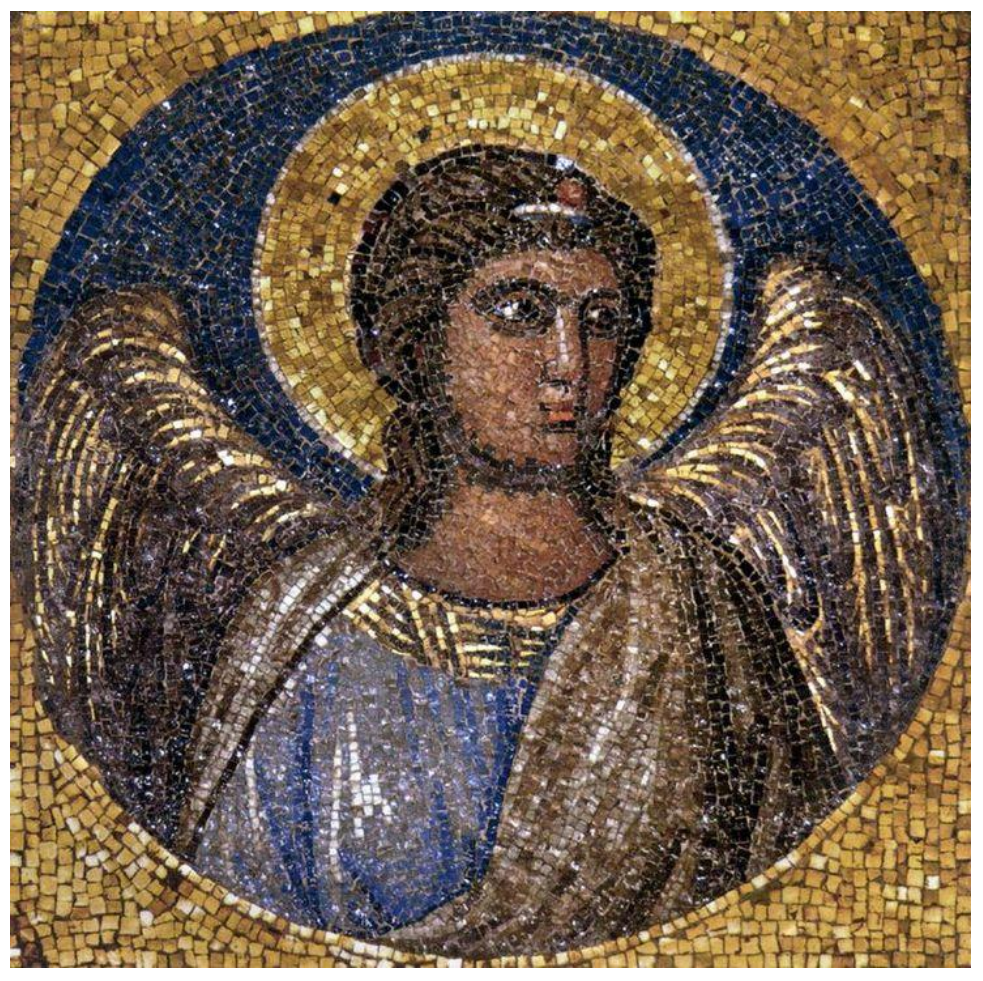

Figure 28: Bust of Angel from decorative frame of Navicella, Boville Ernica (mosaic). 


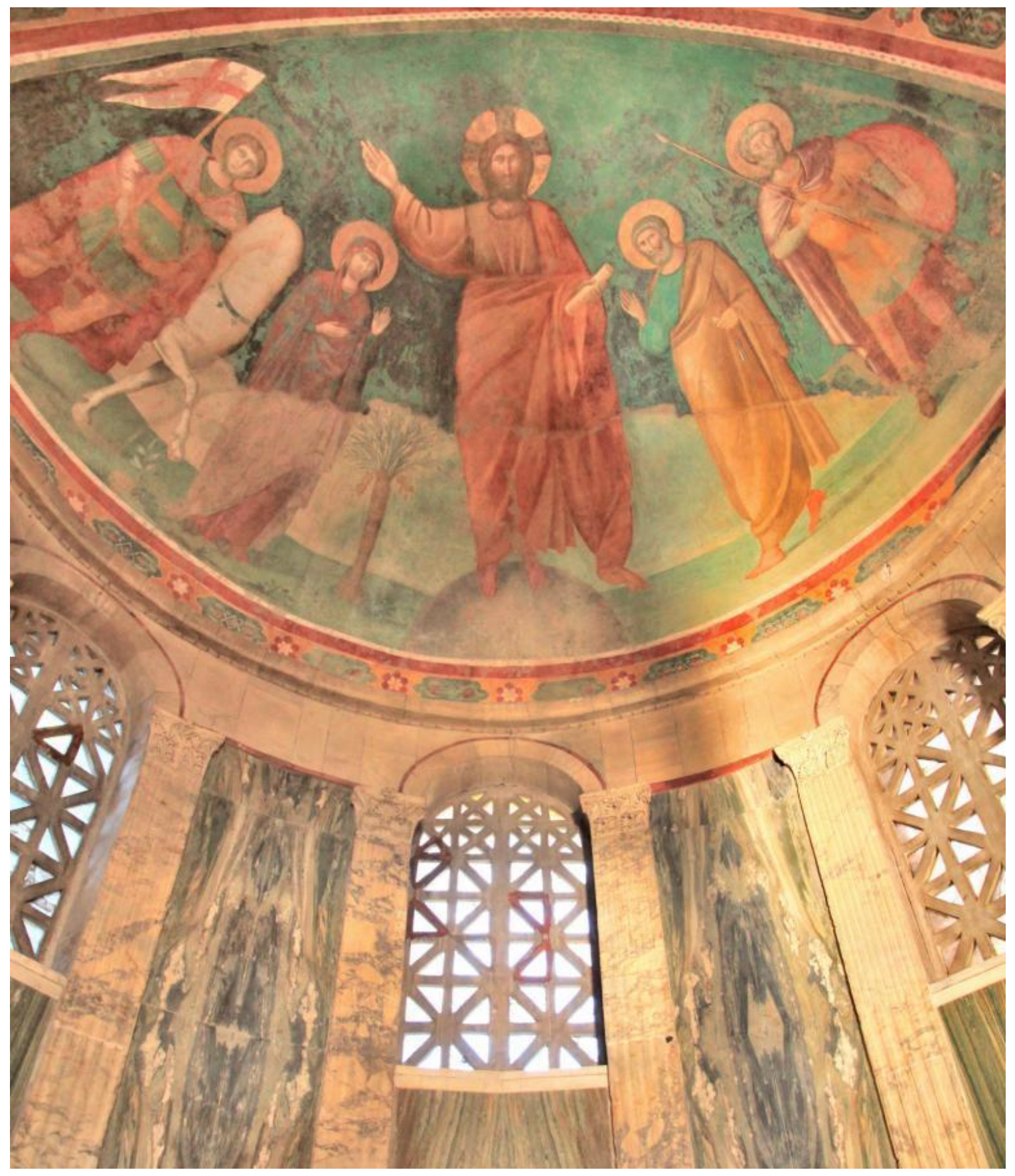

Figure 29: Circle of Pietro Cavallini, Traditio Legis from Apse of San Giorgio in Velabro, late-thirteenth-century (fresco). 


\section{CURRICULUM VITAE}

\section{Eston Dillon Adams}

1310 Kremer Avenue

Louisville, KY 40213

Cell: (502)777-1715

Email: edadam01@cardmail.louisville.edu

DOB: January 8, 1979 - Louisville, KY

\section{EDUCATION}

\& TRAINING:

B.A., Major: Art, Minor: English

University of Louisville, 1997-2002

B.A., Art History

University of Louisville, 2004-2006

Certificate in Medieval and Renaissance Studies

University of Louisville, 2010

Master of Arts: Concentration in Art History

University of Louisville, 2011

PhD in Art History: Specializing in Italian Renaissance Art in Progress, matriculated Spring 2013, entered candidacy Spring 2016

\section{AWARDS:}

Trustees Academic Scholarship, University of Louisville, 1997-2000

T \& JJ Douglas Scholarship, University of Louisville, 2000-2001

Creative Writing Scholarship, University of Louisville, 2000-2001

Trustees Academic Scholarship, University of Louisville, 2001-2002

Cressman Scholarship, University of Louisville, 2007-2008

Toccara Porter Library Scholarship, University of Louisville, 2009-2010

Research Assistantship, University of Louisville, Spring 2013

Graduate Teaching Assistantship, University of Louisville, Fall 
2013-Spring 2017

Graduate Merit Scholarship, 2015-2016

Italian Studies Scholarship, 2015-2016

Graduate Student Travel Scholarship, 2015-2016

Don Payton Graduate Award in Art History, Fall 2017-Spring 2018

Hite Art Institute Individual Student Travel Scholarship, Fall 2017

Doctoral Dissertation Completion Award, Fall 2018

\section{NATIONAL MEETING PRESENTATIONS:}

Virtual Presenter, "A Reconsideration of the Apse of Hagia Eirene" International Conference on the Image, December, 2010, University of California, Los Angeles

Presenter, "Giotto's Navicella in the Renaissance Atrium of Old St. Peter's" Graduate Conference at the Arthur F. Kinney Center for Interdisciplinary Renaissance Studies, October, 2017, University of Massachusetts, Amherst

\section{TEACHING EXPERIENCE:}

University of Louisville - Summer 2007, Fall 2013-Spring 2017

Ancient to Medieval Art History Survey, Renaissance to

Modern Art History Survey, and Introduction to Art

Elizabethtown Community and Technical College -

Fall 2011-Spring 2013, Introduction to Art

\section{RESEARCH:}

M.A. Thesis: A Reconsideration of the Apse of Hagia Eirene.

PhD Dissertation: The History and Signification of the Navicella Mosaic at Saint Peter's Basilica, Rome. 